UNIVERSIDADE DE SÃO PAULO

ESCOLA DE ENFERMAGEM

CRISTINA SILVA SOUSA

EDUCAÇÃO PÓS-OPERATÓRIA: CONSTRUÇÃO E VALIDAÇÃO DE UMA TECNOLOGIA EDUCATIVA PARA PACIENTES SUBMETIDOS À CIRURGIA ORTOGNÁTICA

SÃO PAULO

2011 
CRISTINA SILVA SOUSA

\title{
EDUCAÇÃO PÓS-OPERATÓRIA: CONSTRUÇÃO E VALIDAÇÃO DE UMA TECNOLOGIA EDUCATIVA PARA PACIENTES SUBMETIDOS À CIRURGIA ORTOGNÁTICA
}

\author{
Versão corrigida. A versão original se \\ encontra disponível tanto na Biblioteca \\ da Unidade que aloja o programa \\ quanto na Biblioteca Digital de Teses e \\ Dissertações da USP (BDTD). \\ Dissertação apresentada à Escola de \\ Enfermagem da Universidade de São \\ Paulo, para obtenção do titulo de \\ Mestre em Enfermagem. \\ Área de Concentração: \\ Enfermagem na Saúde do Adulto \\ Orientadora:
}

Prof. ${ }^{\text {a }}$ Dr ${ }^{\text {a }}$ Ruth Natalia Teresa Turrini

\section{SÃO PAULO}


AUTORIZO A REPRODUÇÃO TOTAL OU PARCIAL DESTE TRABALHO, POR QUALQUER MEIO CONVENCIONAL OU ELETRÔNICO, PARA FINS DE ESTUDO E PESQUISA, DESDE QUE CITADA A FONTE.

Assinatura:

Data

Catalogação na Publicação (CIP)

Biblioteca "Wanda de Aguiar Horta"

Escola de Enfermagem da Universidade de São Paulo

Sousa, Cristina Silva

Educação pós-operatória: construção e validação de uma tecnologia educativa para pacientes submetidos à cirurgia ortognática / Cristina Silva Sousa. - São Paulo, 2011.

166 f. : Il.

Dissertação (Mestrado) - Escola de Enfermagem da Universidade de São Paulo.

Orientadora: Profa. Dra. Ruth Natalia Teresa Turrini

1. Deformidades dento-faciais 2. Cirurgia

bucomaxilofacial - Assistência 3. Enfermagem em centro cirúrgico 4. Internet 5. Folhetos I. Título. 
Nome: Cristina Silva Sousa

Titulo: Educação pós-operatória: construção e validação de uma tecnologia educativa para pacientes submetidos à cirurgia ortognática

Dissertação apresentada à Escola de Enfermagem da Universidade de São Paulo, para obtenção do titulo de Mestre em Enfermagem.

Área de Concentração: Enfermagem na Saúde do Adulto

Aprovação em Dezembro de 2011

\section{Banca Examinadora}

Prof. Dr $^{\mathrm{a}}$ Ruth Natalia Teresa Turrini (orientadora) - Escola de Enfermagem - EEUSP

Julgamento:

Assinatura:

Prof. ${ }^{a} \mathrm{Dr}^{\mathrm{a}}$

Julgamento:

Assinatura:

Prof. ${ }^{a} \mathrm{Dr}^{\mathrm{a}}$

Julgamento:

Assinatura: 
Dedico este trabalho ao men grande amor, que me apoía em todos os meus sonhos; acredita no meu potencial; me auxilia nos momentos mais dificeis; me orienta nas coisas da vida. Sem você minha vida não tería graça e nada disso sería realidade.

"Amar de olhos fechados é amar como cego. Amar de olhos abertos é amar talvez como louco: é aceitar perdidamente. Amo-te como louca." 


\section{Agradecimentos}

A minha orientadora que abraçou minhas ideias e me auxilion a torna-las realidade, contribuiu com seu conhecimento e me permitiu partilhar de tudo isso;

A professora Maria cecilía Focesi Pelicioni que cruzon meu caminho e carinhosamente me auxilion nos momentos de dúvidas, partilhando seu conhecimento na área educacional e de promoção de saúde;

As alunas de graduação Bruna do Rego Barros e Maríana Rodrígues dos santos, que participaram na coleta dos dados gerados nesta pesquisa;

Aos cirurgiões, nutricionistas, enfermeiras e fonoaudiólogas que fizeram parte desta pesquisa e contribuiram com seus conhecimentos para que fosse possivel construir este material educativo;

Aos pacientes que participaram deste processo, sua contribuição foi de grande valía para seguír com o projeto;

Ao ilustrador Marcio Batista que aceitou o desafio de realizar as ilustrações desta pesquisa;

As professoras da EEUSP que cruzaram men caminho $e$ acrescentaram conhecimento no meu percurso acadêmico;

As minhas amigas que me apoiaram nos momentos mais exaustivose tiveram compreensão nos meus períodos de ausêncía;

E a todos aqueles que fizeram com que este trabalho fosse realizado. 
Sousa CS. Educação pós-operatória: construção e validação de uma tecnologia educativa para pacientes submetidos à cirurgia ortognática [dissertação]. São Paulo: Escola de Enfermagem, Universidade de São Paulo; 2011.

\section{RESUMO}

A cirurgia ortognática consiste na correção de deformidades dentofaciais e visa à melhora do paciente no sentido estético, funcional e anatômico da estrutura da face. Dado o aumento da prevalência desta modalidade cirúrgica e a carência de informações destinadas ao paciente submetido a esse procedimento, este estudo teve por objetivo a construção e a validação de um material educativo. A trajetória metodológica envolveu cinco fases: revisão integrativa sobre as complicações cirúrgicas; busca na Internet sobre blogs e comunidades virtuais de pacientes submetidos a cirurgia ortognática para conhecer a população e sua necessidade de informação; realização de um grupo focal com pacientes submetidos a cirurgia ortognática para levantamento das necessidades de educação perioperatória; informação dos juízes sobre orientação feita ao paciente; construção do material educativo e validação do conteúdo técnico junto a juízes quanto a pertinência e categorias de avaliação de um material educativo aplicando a técnica Delphi; e posteriormente a clareza de conteúdo foi validada junto aos pacientes em pósoperatório de cirurgia ortognática. Os resultados referentes ao conhecimento da população demonstraram a necessidade de informação dos internautas quanto à: dúvidas e medos relativos ao procedimento, recuperação, alteração da estética facial, arrependimento após procedimento. No grupo focal, os pacientes expuseram dificuldades vivenciadas pelo edema facial e parestesia, discutiram tempo de recuperação da cirurgia, questões de autoimagem, resultados estéticos e propuseram melhor momento para entrega do material. Na primeira rodada da técnica Delphi, os juízes citaram orientações pertinentes ao período perioperatório, destacando-se: higiene oral, parestesia, edema facial, dificuldade respiratória e mastigatória, alteração da voz e movimentos musculares pós-operatórios e dieta liquida. A segunda rodada da técnica Delphi consistiu na avaliação do material educativo pelos juízes, que resultou 38,2\% (84) concordo e $61,3 \%$ (135) concordo totalmente para as seis categorias do instrumento. Realizadas as correções sugeridas pelos juízes um novo material foi submetido à avaliação na terceira rodada da técnica Delphi e obtidos $30,9 \%$ (68) concordo e $68,6 \%$ (151) concordo totalmente, dando como finalizado esta fase. Submetido ao paciente para avaliar compreensão, obteve-se 33,8\% (176) concordo e 59,6\% (310) concordo totalmente, sem sugestões para alterações do texto e foi mantido o material apresentado. Conclui-se que a construção do material educativo é um processo que envolve profissionais e público alvo para alcançar níveis elevados de aceitação e aderência do material, sendo que este deve ser utilizado como forma complementar de orientação ao paciente.

PALAVRAS CHAVE: Cirurgia Ortognática, Internet, Assistência perioperatória, Materiais educativos e de divulgação, Enfermagem Perioperatória. 
Sousa CS. Post-operative Education: construction and validation of an educational technology for patients undergoing orthognathic surgery [dissertação]. São Paulo: Escola de Enfermagem, Universidade de São Paulo; 2011.

\section{ABSTRACT}

The orthognathic surgery consists of correcting dental facial deformities and aims to improve esthetical, functional and anatomical features of the structure of the patient's face. Given the increased prevalence of this surgical modality and a lack of information available to patients undergoing this procedure, this study presents the construction and validation of educational material. The methodological trajectory involved five phases: integrative review on surgical complications; search on the internet on blogs and virtual communities of patients undergoing orthognathic surgeries aiming to know the population and its need of information; a focal group with patients undergoing the procedure to identify the need of perioperative education; experts' information concerning guidance provided to patients; construction of educational material and validation of technical content by experts concerning the relevance and categories of validation of education material using the Delphi technique; clarity of content was validated with patients in the postoperative period. The results concerning knowledge of the population show the need to inform Internet users about doubts and fear related to the procedure, recovery, changes in facial esthetics, regret after the procedure. Patients exposed in the focal group the difficulties experienced given the facial edema and paresthesia, discussed time of surgery recovery, self-image issues, aesthetical results and suggested the most opportune time to provide the material. In the first round of the Delphi technique, experts cited guidance related to the perioperative period and the following stood out: oral care, paresthesia, facial edema, difficulty breathing and chewing, changes in voice and muscle movements after the surgery and liquid diet. The second round of the Delphi technique consisted of the evaluation of the educational material by experts: $38.2 \%$ (84) agreed and $61.3 \%$ (135) totally agreed with the instrument's six categories. The material with the corrections suggested by the experts was submitted to evaluation in the third round of the Delphi technique and $30.9 \%$ (68) agreed and $68.6 \%$ totally agreed with it and this phase was completed. When the instrument was submitted to patients to evaluate understanding, 33.8\% (176) agreed and 59.6\% (310) totally agreed; no suggestions to change the text were suggested and this was considered the final version. The conclusion is that the construction of educational material is a process that involves professionals and the target public to achieve high levels of acceptance and adherence to material, which should be used as an adjuvant to guidance provided to patients.

KEYWORDS: Orthognathic surgery, Internet, Perioperative Care, Educational and Promotional Materials, Perioperative nursing. 


\section{LISTA DE ILUSTRAÇÕES}

Figura 1 - Deformidades dentofaciais: mordida aberta, retrognatismo e prognatismo.

Figura 2 - "Splint" ou guia cirúrgico no articulador em modelo de gesso da mordida antes e planejamento para cirurgia.

Figura 3 - Paciente com retrognatismo (antes e depois da cirurgia)

Figura 4 - Paciente com prognatismo (antes e depois da cirurgia).

Figura 5 - Paciente com mordida aberta (antes e mordida aberta corrigida após a cirurgia).

Figura 6 - (A) Paciente após cirurgia ortognática combinada (procedimento em maxila e mandíbula). (B) Paciente com assimetria facial (antes e depois da cirurgia)

Figura 7 - Disjunção maxilar

Figura 8 - Mentoplastia para promentonismo.

Figura 9 - Mapa conceitual da metodologia aplicada nesta pesquisa.

Figura 10 - Diagrama do processo de seleção dos artigos nas bases de dados

Figura 11 - Sequência da técnica Delphi

Figura 12 - Apresentação das rodadas propostas com a técnica Delphi. 


\section{LISTA DE TABELAS}

Tabela 5.1 - Complicações distribuídas conforme população encontrada nos estudos.

Tabela 5.2- Frequência de comentários encontrados e selecionados segundo comunidades virtuais e blogs

Tabela 5.3 - Distribuição dos juízes segundo a profissão e medidas descritivas da variável idade

Tabela 5.4 - Distribuição de juízes segundo profissão e medidas descritivas da variável tempo de formação

Tabela 5.5 - Distribuição dos juízes quanto a titulação e profissão

Tabela 5.6 - Distribuição da frequência absoluta de escores obtidos por juízes segundo os itens do instrumento na segunda rodada da técnica Delphi.

Tabela 5.7 - Distribuição dos valores de soma (S), média (M) e porcentagem (\%) dos itens por juiz.

Tabela 5.8 - Dados quantitativos referente as questões dissertativas do instrumento

Tabela 5.9 - Distribuição da frequência absoluta de escores obtidos por juízes segundo os itens do instrumento na terceira rodada da técnica Delphi.

Tabela 5.10 - Distribuição dos valores de soma (S), média (M) e porcentagem (\%) dos itens por juiz.

Tabela 5.11 - Distribuição da frequência absoluta de escores obtidos por pacientes segundo os itens do instrumento de avaliação do material educativo 


\section{LISTA DE QUADROS}

Quadro 5.1 - Roteiro produzido para condução do grupo focal I.

Quadro 5.2 - Roteiro produzido para condução do grupo focal II.

Quadro 5.3 - Roteiro para avaliação do desempenho do grupo I e II

Quadro 5.4 - Identificação dos pacientes do grupo focal de pósoperatório, segundo sexo, idade e tempo de cirurgia.

Quadro 5.5 - Identificação dos pacientes do grupo focal de préoperatório, segundo sexo, idade e tempo previsto para cirurgia.

Quadro 5.6 - Identificação dos juízes segundo sexo, idade, área de trabalho e tempo de formação profissional.

Quadro 5.7 - Distribuição das respostas da primeira fase da técnica Delphi.

Quadro 5.8 - Distribuição das respostas da primeira fase da técnica Delphi separadas por categoria.

Quadro 5.9 - Alterações realizadas no material educativo após avaliação dos juízes na segunda rodada da técnica Delphi

Quadro 5.10 - Alterações realizadas no material educativo após avaliação dos juízes na terceira rodada da técnica Delphi.

Quadro 5.11 - Características sócio demográficas, tempo de preparo cirúrgico dos pacientes que validaram o material educativo para cirurgia ortognática 


\section{SUMÁRIO}

1 JUSTIFICATIVA DO ESTUDO

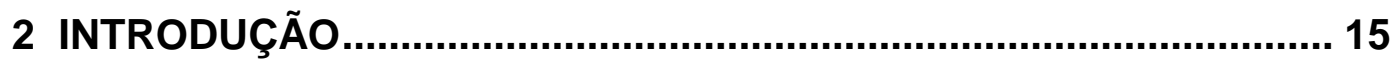

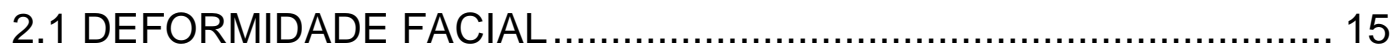

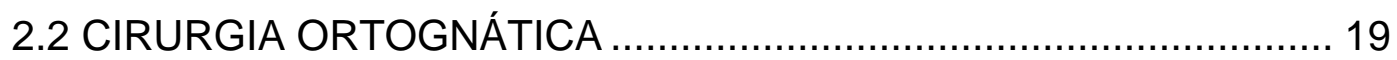

2.2.1 PLANEJAMENTO CIRURGICO …………………………………...... 21

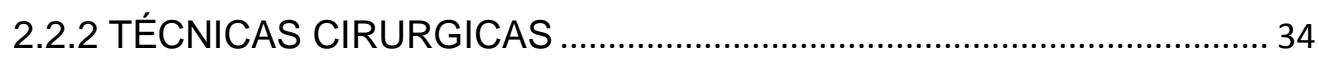

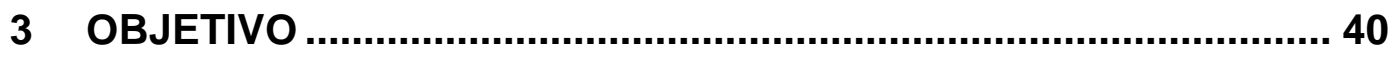

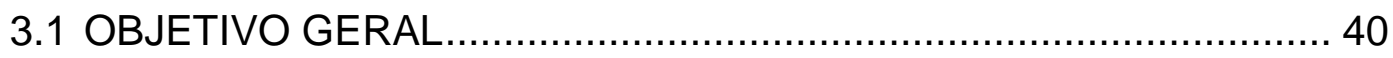

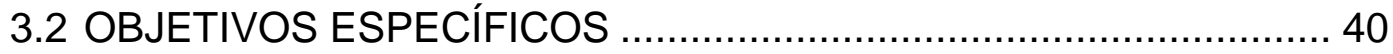

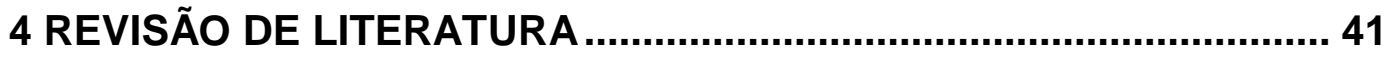

4.1 EDUCAÇÃO PÓS OPERATÓRIA ..................................................... 41

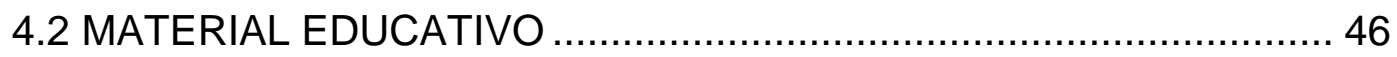

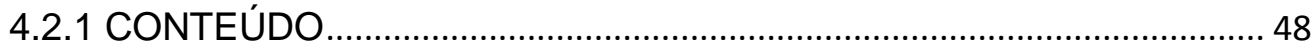

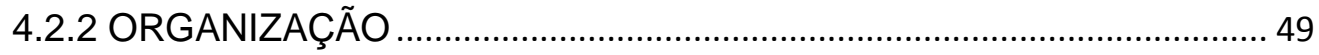

4.2.3 LEIAUTE E TIPOGRAFIA ………………………………………….... 49

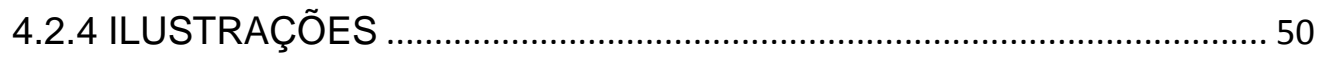

4.2.5 APRENDIZAGEM E MOTIVAÇÃO ....................................................... 51

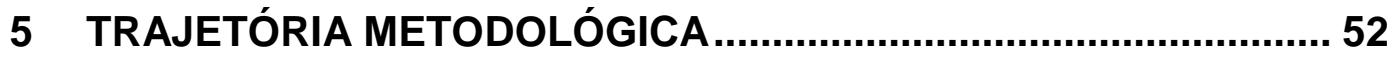

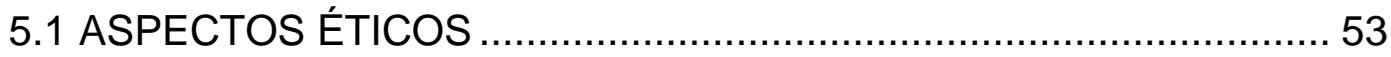

5.2 PRIMEIRA FASE - REVISÃO DE LITERATURA ............................ 53

5.2.1 MATERIAL E MÉTODO ……………………………………………..... 53

5.2.2 RESULTADOS................................................................................. 55

5.3 SEGUNDA FASE - CONHECIMENTO DOS INTERNAUTAS ........... 56

5.3.1 MATERIAL E MÉTODOS........................................................................ 56

5.3.2 RESULTADOS …………………………………………………..... 58

5.4 TERCEIRA FASE - PERCEPÇÃO DOS PACIENTES SOBRE O PÓSOPERATÓRIO DE CIRURGIA ORTOGNÁTICA …............................... 67

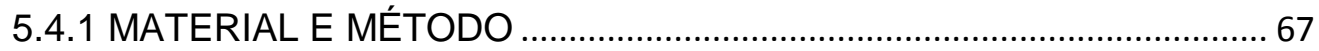


5.4.2 RESULTADOS

5.5 QUARTA FASE - CONSTRUÇÃO DO MATERIAL EDUCATIVO E AVALIAÇÃO PELOS JUÍZES ................................................. 83

5.5.1 MATERIAL E MÉTODO ....................................................................... 83

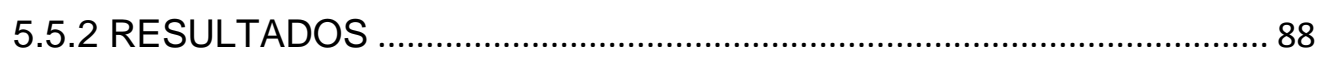

5.6 QUINTA FASE - APLICAÇÃO DO MATERIAL EDUCATIVO AOS PACIENTES ................................................................................. 113

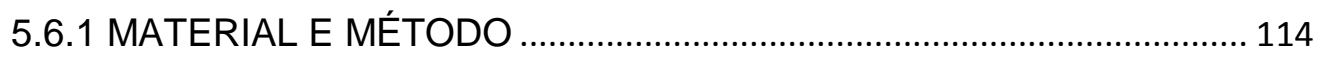

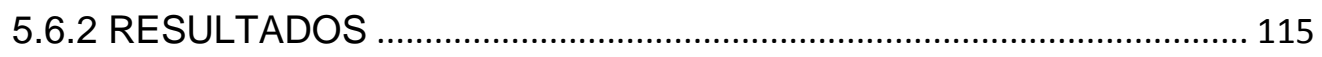

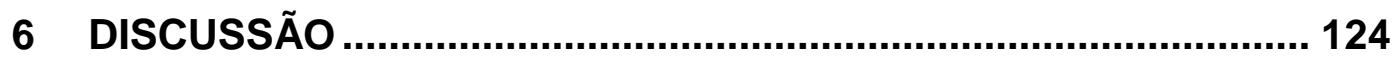

7 CONSIDERAÇÕES FINAIS ....................................................... 135

REFERÊNCIAS ........................................................................... 138

APENDICE A.............................................................................. 152

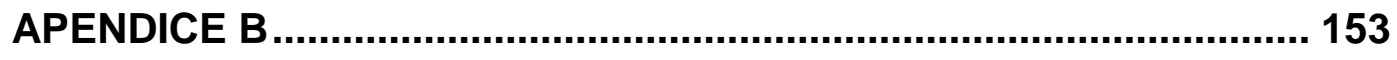

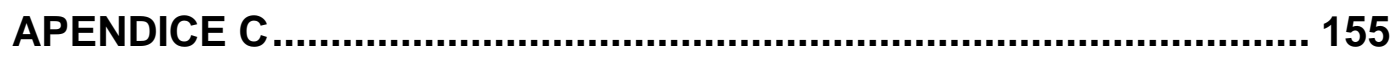

APENDICE D......................................................................... 157

APENDICE E .......................................................................... 158

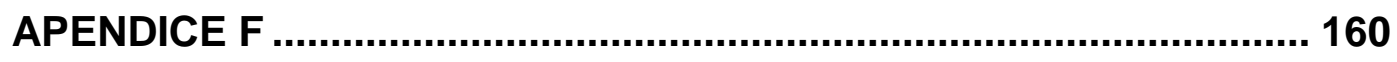

APENDICE G........................................................................ 161

APENDICE H...................................................................... 162

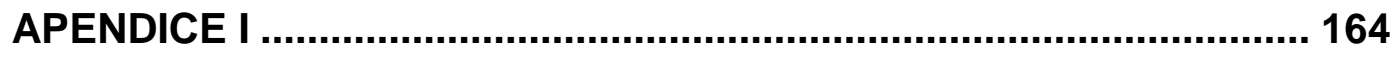

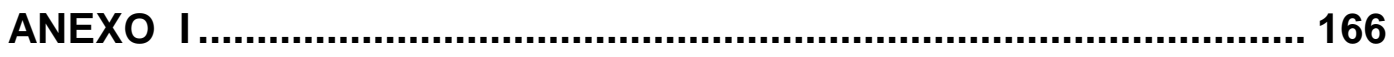




\section{JUSTIFICATIVA DO ESTUDO}

A cirurgia ortognática é uma modalidade cirúrgica que visa a melhora do paciente no sentido estético, funcional e anatômico da estrutura da face. Tem sido crescente a prevalência deste tipo de procedimento na área hospitalar, sendo necessários cuidados de enfermagem direcionados à área para promover uma recuperação rápida e eficaz, além de auxiliar na orientação do paciente para os cuidados domiciliares após a alta hospitalar.

Este estudo se propõe a elaborar um material educativo para orientação de cuidados pós-operatórios para cirurgia ortognática que será utilizado no período perioperatório, permitindo maior interação com o paciente e criando o vínculo de confiança necessário para amenizar a ansiedade, estimular a credibilidade e a prontidão para seguir o tratamento proposto e diminuir prováveis complicações.

O fator motivacional para a realização deste estudo foi decorrente da minha experiência profissional como enfermeira de centro cirúrgico: a pouca informação dada ao paciente em seu pré e pós-operatório. A educação perioperatória pode propiciar a intervenção precoce das intercorrências clínicas e psicológicas, tais como, perda significativa de peso por limitação da alimentação, fadiga, sangramento oral, depressão pós-operatória por autorreprovação, culpa inapropriada e etnia diferente (ao alterarem a estética facial diferencia-se o paciente de seus familiares por perder as características da raça e sente-se excluído ou diferente dos seus). A insatisfação com o resultado da cirurgia pode ocorrer em pacientes ansiosos ou com autopercepção distorcida. Além disso, nota-se crescente demanda de pacientes deste grupo cirúrgico procurando informações sobre o pósoperatório em blogs e comunidades virtuais.

Este estudo poderá ampliar o campo de atuação da enfermeira neste tipo de procedimento, suprindo esta população que carece de informações pela não aplicabilidade de um instrumento para orientação específica. 


\section{INTRODUÇÃO}

\subsection{DEFORMIDADE FACIAL}

A deformidade dentofacial é caracterizada pela desarmonia das estruturas esqueléticas da face, que pode resultar na má oclusão dentária e desequilíbrio do sistema neuromuscular, provocando alterações em funções essenciais como a respiração, a mastigação, a fonação e na estética da face, interferindo no aspecto social e psicológico do paciente.

As causas da deformidade envolvem má formação congênita, seja por alteração no desenvolvimento embrionário ou fator teratogênico; fatores ambientais, tais como: distúrbio de crescimento após nascimento, traumatismo durante o parto e queda na infância, levando a fraturas de mandíbula e côndilo sem correção cirúrgica imediata que posteriormente interferem no desenvolvimento dos ossos da face; fatores funcionais em que ocorre alteração do padrão mastigatório (mordida cruzada, mordida unilateral); fatores de desenvolvimento, por crescimento inadequado de padrão esquelético ou dentário (dentes extranumerários, anquilose de articulação temporomandibular) ${ }^{1,2}$.

Dentre os tipos de deformidade facial estão:

- A mandíbula numa posição mais avançada que o maxilar (protusão da mandíbula denominada prognatismo mandibular);

- A mandíbula numa posição mais recuada que o maxilar (retração da mandíbula denominada retrognatismo mandibular);

- A maxila numa posição mais avançada que a mandíbula (protusão da maxila denominada prognatismo maxilar);

- A maxila numa posição mais recuada que a mandíbula (retração da maxila denominada retrognatismo maxilar); 
- Alongamento ou encurtamento da face (exposição dentária e gengival excessiva ou falta da exposição dentária ao sorrir, denominadas alterações verticais da maxila);

- Assimetrias da mandíbula;

- Assimetria da face (envolvem alterações de nariz e demais ossos da face).

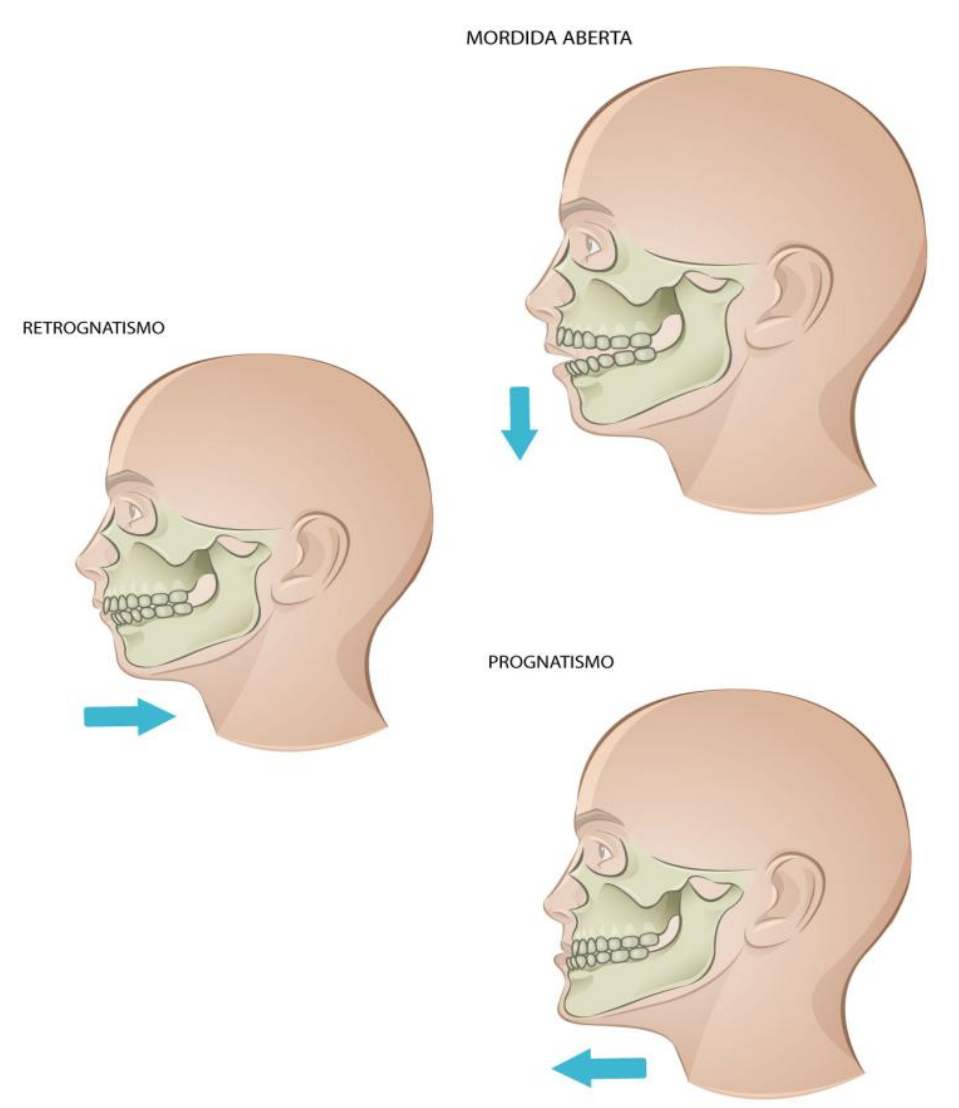

Figura 1 - Deformidades dentofaciais: mordida aberta, retrognatismo e prognatismo

Para classificar a má oclusão dentária e promover o tratamento adequado a cada paciente é comum utilizar a Classificação de Angle, descrita pela primeira vez em 1899, por Angle em seu clássico artigo no qual propôs a classificação das más-oclusões, baseado na premissa de que para o diagnóstico correto de uma má oclusão é necessária a familiarização com a oclusão normal e linhas faciais normais ${ }^{4}$. Esta classificação consiste em dividir a má oclusão em três classes: 
Classe I: a cúspide mésio-vestibular do primeiro molar superior oclui no sulco entre as cúspides mesial e distal do inferior. A relação anteroposterior está correta, com os molares em posição de oclusão normal e um ou mais dentes anteriores em maloclusão. Considerada oclusão normal.

Classe II: relação mésio-distal anormal dos molares, com dentes inferiores ocluindo para distal em relação a oclusão normal, produzindo uma desarmonia na região incisiva e nas linhas faciais (característica de paciente chupador de dedo ou chupeta).

Esta classificação possui duas subdivisões de acordo com a inclinação dos incisivos superiores. A primeira divisão é caracterizada pela inclinação protusiva destes dentes, acompanhada de função anormal dos lábios e alguma forma de obstrução nasal e respiração bucal. A segunda divisão é caracterizada pela inclinação lingual dos incisivos superiores, geralmente associada à função labial e nasal normal.

Classe III: relação mésio-distal anormal dos molares, porém com dentes inferiores ocluindo para mesial em relação à oclusão normal, causando um cruzamento na região anterior e uma inclinação lingual excessiva dos incisivos inferiores devido a pressão do lábio inferior exercida durante o fechamento da boca.

Para a correta avaliação da deformidade dentofacial é requerida além da classificação de $A n g l e^{3}$, uma classificação esqueletal da face, podendo ser aplicada a Classificação de Simon $^{5}$, que consiste em relacionar os arcos dentários com os planos antropológicos, permitindo avaliar a simetria facial da seguinte forma:

Desvio do plano orbital: quando o arco dentário, ou parte dele, está localizado mais anteriormente que o normal em relação ao plano orbital. Neste caso, denomina-se protração e quando está situado posteriormente em relação ao plano orbital, denomina-se retração. 
Desvio do plano sagital: quando o arco dentário ou parte dele está mais próximo do plano sagital médio do que a posição normal, diz-se que está em contração. Quando está mais afastado, diz-se que está em distração.

Desvio do plano de Frankfurt: quando o arco dentário, ou parte dele, está mais próximo do plano de Frankfurt do que a posição normal, diz-se que está em atração (intrusão dos dentes maxilares ou extrusão dos dentes mandibulares). Quando está mais afastado deste plano do que a posição normal, diz-se que está em abstração.

A prevalência dos pacientes com deformidade dentofacial existente na comunidade não é descrita em estudos nacionais ou internacionais. É descrita apenas a prevalência de pacientes com deformidade dentofacial que buscam tratamento nos serviços de cirurgia e traumatologia bucomaxilofacial.

No Brasil, um estudo realizado na cidade de Bauru, no período de 2006 a 2008, registrou no ambulatório do serviço de cirurgia e traumatologia bucomaxilofacial a prevalência de $15 \%$ má oclusão de Classe I, 31\% de Classe II e 54\% de Classe 1 II $^{6}$. Em Maringá, um estudo com pacientes atendidos entre 1997 a 2003, no ambulatório do serviço de cirurgia e traumatologia bucomaxilofacial, encontrou $2 \%$ na Classe I, 33\% na Classe II e $53 \%$ na Classe $1 \mathrm{II}^{6,7}$.

Na Europa, um estudo realizado no Hospital Universitário de Oslo (Noruega), no período de 1994 a 2002, registrou atendimentos no ambulatório de cirurgia maxilofacial de 15\% na Classe I, 30\% na Classe II, $55 \%$ na Classe III $^{8}$.

Esses estudos mostram uma semelhança na prevalência de casos atendidos nos ambulatórios nacionais e internacionais, e demonstram que a procura pelo atendimento no serviço de cirurgia e traumatologia bucomaxilofacial é maior pelos pacientes que possuem a deformidade dentofacial Classe II e Classe III de Angle. 
Em todos os estudos, o tratamento da deformidade dentofacial é requerido e aplicado individualizado, com base no exame clínico, cefalométrico e de imagem; quando indicado tratamento cirúrgico, são aplicadas classificações de arco dentário e esqueletal e realizados exames pré-operatórios. A cirurgia ortognática é a proposta de correção cirúrgica para tratamento da mordida cruzada, aberta e deformidades faciais Classe II e III de Angle.

\subsection{CIRURGIA ORTOGNÁTICA}

A cirurgia ortognática consiste em técnicas de osteotomias realizadas no sistema mastigatório, com o objetivo de corrigir as discrepâncias relacionais maxilares e, por conseguinte, estabelecer 0 equilíbrio entre a face e 0 crânio ${ }^{9}$ A cirurgia ortognática busca 0 alinhamento da maxila e mandíbula para correções de deformidades faciais e maxilomandibulares, com um posicionamento dentário adequado ${ }^{10}$.

Entretanto, mais ampla que apenas um procedimento cirúrgico, a cirurgia ortognática é descrita como um procedimento combinado entre a ortodontia e a cirurgia bucomaxilofacial, visando à correção de deformidades dentoesqueléticas ${ }^{11 .}$

A primeira osteotomia com esta finalidade foi executada em 1849 por Simon $\mathrm{H}$. Hullieh, de Wheeling da Virginia Oeste ${ }^{12}$. No Brasil essa cirurgia foi introduzida em 1979 pelo professor Antenor Araújo; entretanto houve uma evolução no decorrer destes anos, tanto na técnica cirúrgica quanto no material utilizado, propiciando um pós-operatório com recuperação rápida e retorno às atividades pessoais do paciente mais brevemente $^{13 .}$

O aprimoramento das técnicas cirúrgicas e o desenvolvimento de novos materiais de fixação fizeram com que os problemas de recidiva pós- 
cirurgia fossem minimizados, o que tornou o procedimento mais seguro, com técnicas mais aceitáveis e tratamento mais receptivo pelo paciente ${ }^{14}$.

Por ser um procedimento realizado há pouco tempo no Brasil, o quantitativo cirúrgico é pouco mensurado. Estudos nacionais relataram 239 cirurgias realizadas em Porto Alegre, no período de cinco anos; 180 cirurgias em Maringá no período de seis anos; 56 cirurgias em Bauru no período de dois anos ${ }^{6,15}$. Um estudo internacional apresentou 516 cirurgias realizadas em Oslo (Noruega) no período de oito anos ${ }^{8}$.

Problemas relacionados à região bucomaxilofacial acarretam péssimas funções mastigatórias, insatisfação com as condições orais e precária qualidade de vida ${ }^{16 .}$

Os benefícios deste tipo de procedimento cirúrgico são descritos como melhora na habilidade de mastigar, deglutir, falar e respirar e, em muitos casos, uma aparência facial mais estética.

Os resultados de uma cirurgia ortognática levam a uma harmonia estética-ocluso-facial e podem proporcionar uma verdadeira transformação na relação interpessoal e na autoestima.

É importante salientar que a indicação cirúrgica deverá ser baseada na disfunção funcional do aparelho mastigatório e não apenas na estética. Algumas condições podem indicar a necessidade de cirurgia ortognática: dificuldade de manter lábios em contato sem esforço, abertura de boca, mastigação e fala, dor mandibulomaxilar crônica, apinhamentos dentários excessivos, mordida aberta, ausência de balanceamento da aparência facial, defeitos congênitos, mento retraído, mandíbula protruida, respiração bucal crônica com xerostomia e apneia do sono ${ }^{10}$.

Entende-se que a necessidade da intervenção cirúrgica está voltada para adaptação funcional e melhor qualidade de vida e que as complicações do procedimento cirúrgico diminuíram com a evolução da técnica aplicada e o desenvolvimento do cirurgião. 
Vale lembrar que todo o procedimento cirúrgico possui riscos e possíveis complicações. O paciente deve estar ciente disso antes de consentir com o procedimento cirúrgico. O termo "complicação" caracteriza um evento adverso e inesperado que resulta em um aumento da morbidade, além do que esperaríamos em circunstâncias normais ${ }^{17}$.

Assim, um planejamento cirúrgico adequado pode prevenir riscos, complicações e promover um procedimento seguro, obtendo um resultado satisfatório.

\subsubsection{PLANEJAMENTO CIRURGICO}

O primeiro contato com o paciente ocorre na consulta com o cirurgião bucomaxilofacial, onde são realizados a anamnese, a coleta da história clínica e o esclarecimento do motivo que levou o paciente a buscar atendimento (estético, funcional ou ambos). Nesta consulta são solicitados exames radiológicos (radiografia panorâmica e cefalometria) e documentação ortodôntica completa para complementação do diagnóstico.

A radiografia panorâmica permite a avaliação de todos os dentes de uma única vez, auxiliando também no diagnóstico de distúrbios ósseos da face. A cefalometria permite ao cirurgião analisar a combinação das medidas angulares e lineares da face em plano frontal e lateral, e avaliar o crescimento e desenvolvimento craniofacial $^{18}$.

No retorno ao consultório é definido o tipo de deformidade facial apresentada pelo paciente e o plano de tratamento necessário (uma combinação de ortodontia pré-operatória, cirurgia ortognática e ortodontia pós-operatória) que leva em torno de dois anos de tratamento.

\subsubsection{FASE PRÉ-OPERATÓRIA}

Na fase pré-operatória, o cirurgião orienta o paciente quanto ao tipo de deformidade dentofacial, avalia expectativas e estado psicológico, além de confirmar se o paciente está suficientemente motivado para o longo tratamento requerido até o resultado final. 
A decisão de fazer o tratamento cirúrgico deve partir do paciente. $O$ profissional e a família não devem induzi-lo à realização de um procedimento cirúrgico que irá produzir alterações irreversíveis na sua face e eventualmente com repercussões sobre sua personalidade ${ }^{9}$.

A cirurgia é contraindicada para mulheres menores de 16 anos e homens menores de 18 anos, por haver crescimento ósseo até esta faixa etária. Se o procedimento cirúrgico é realizado em crianças ou adolescentes, pode haver necessidade de reintervenção cirúrgica quando atingirem a idade adulta $^{19}$

Estando o paciente orientado e concordando com o diagnóstico e o tratamento, ele é encaminhado ao ortodontista para que inicie o tratamento com o preparo prévio ortodôntico.

O paciente encontra-se pronto para cirurgia quando os arcos dentários superior e inferior estiverem alinhados e nivelados. Neste momento, são realizadas moldagens de arcada superior e inferior e verificase a oclusão fora da boca, simulando o posicionamento que será dado na cirurgia. $O$ encaixe da oclusão dentária deve ser perfeito e, caso haja interferências na oclusão dentária, estas devem ser corrigidas imediatamente ${ }^{14 .}$

É realizada, então, a confecção de um modelo de gesso que, colocado em um aparelho articulador, permite a simulação da posição da arcada dentária após a cirurgia. Sobre este modelo é confeccionada a goteira (splint), um guia cirúrgico em resina acrílica que será responsável por guiar a maxila para sua nova posição em relação à base do crânio durante a cirurgia $^{14 .}$
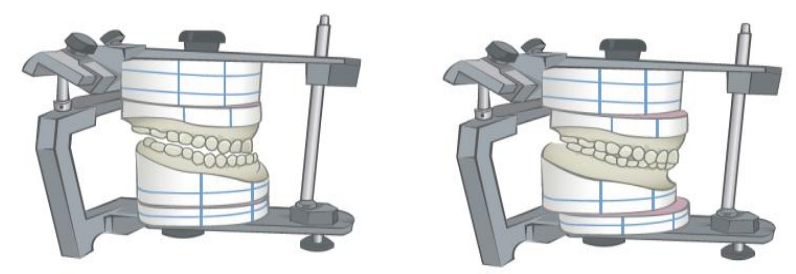

Figura 2 - "Splint" ou guia cirúrgico no articulador em modelo de gesso, mordida antes e depois do planejamento para cirurgia. 
Durante esse período de preparo ortodôntico, o paciente terá consultas periódicas com 0 cirurgião bucomaxilofacial para acompanhamento do tratamento ortodôntico.

Na prática atual, não há intervenção da enfermagem durante este período de planejamento cirúrgico e preparo ortodôntico. As ações da enfermagem se iniciam na internação hospitalar.

Durante o planejamento, podem ocorrer algumas complicações resultantes da possível falha de comunicação das equipes de ortodontia e cirurgião acarretando um planejamento de forma inadequada. A falta de concordância entre profissionais traz muita insegurança aos pacientes, além de afetar a credibilidade científica da especialidade ${ }^{4}$.

A falta de comunicação entre ortodontista e paciente pode resultar em diferentes expectativas em relação ao tratamento por ambas as partes, por isso, o profissional deve ter sensibilidade para interpretar as preocupações, necessidades e desejos do paciente, pois nem sempre a preocupação do ortodontista é a mesma que a do paciente ${ }^{20}$.

Outra possível complicação está ligada à imperícia na obtenção de dados do paciente, bem como à montagem incorreta do modelo no articulador, que resultará em diferenças entre o planejado e o obtido ${ }^{21 .}$

Estando devidamente preparado pelo ortodontista, inicia-se o preparo pré-operatório com a solicitação de exames laboratoriais (hemograma, coagulograma, bioquímica), radiografia de tórax e eletrocardiograma, se houver indicação. Uma avaliação de um especialista pode ser solicitada para avaliar o risco cirúrgico. Nesta consulta o paciente é orientado sobre como será realizado o procedimento cirúrgico, suas possíveis complicações e é assinado o termo de consentimento cirúrgico pelo cirurgião e pelo paciente ${ }^{22 .}$

Um diagnóstico incorreto pode submeter o paciente a uma cirurgia desnecessária, por isso é importante a avaliação de um especialista que estabeleça um relacionamento cirurgião-paciente baseado em confiança e profissionalismo. 
No retorno ao consultório com os exames realizados, não havendo nenhuma contraindicação clínica, o procedimento cirúrgico é marcado pelo cirurgião. O paciente é orientado quanto aos procedimentos para internação cirúrgica e tempo de jejum necessário.

É importante conhecer as expectativas dos pacientes, pois estas estão relacionadas diretamente com o nível de satisfação pós-operatória. Pacientes com pobre suporte social, pessimistas e ansiosos apresentam maiores riscos de complicações ${ }^{9}$.

O processo de reparação da deformidade dentofacial necessita de cooperação do paciente e exige do profissional uma conduta integradora no trabalho em equipe multiprofissional ${ }^{23}$.

A enfermeira tem papel fundamental neste processo de atendimento ao paciente cirúrgico, uma vez que cabe a ela a educação do paciente sobre o procedimento cirúrgico, cuidados pós-operatórios e possíveis complicações. É importante para a enfermeira responder aos questionamentos do paciente, esclarecer suas dúvidas e prepará-lo para o autocuidado no pós-operatório ${ }^{24 .}$

O sucesso do procedimento cirúrgico depende, além do procedimento cirúrgico, de uma assistência de enfermagem a ser prestada de maneira especifica e que deve ocorrer em três momentos distintos: período pré-operatório, transoperatório e pós-operatório ${ }^{25}$.

$\mathrm{Na}$ atenção ao paciente pré-cirúrgico, a equipe de enfermagem é responsável pelo seu preparo, estabelecendo e desenvolvendo diversas ações de cuidados de enfermagem. Estes cuidados são descritos como orientação, preparo físico e emocional, avaliação pré-operatória e encaminhamento ao centro cirúrgico com a finalidade de aumentar a segurança do paciente, promover a recuperação e evitar complicações no intra e pós-operatório, uma vez que estas geralmente estão associadas a um preparo pré-operatório inadequado ${ }^{26 .}$ 
A orientação pré-operatória destina-se a instruir o paciente sobre 0 procedimento cirúrgico, a unidade de recuperação pós-operatória e as responsabilidades que envolvem o procedimento, bem como os sinais e sintomas possíveis no pós-operatório imediato (náuseas, vômitos, sangramento oral, edema, dor) ${ }^{24}$.

$\mathrm{Na}$ admissão pré-operatória cabe à enfermeira confirmar o tempo de jejum, presença de alergias a medicamentos e soluções e antecedentes pessoais, bem como realizar o preparo deste paciente, se for o caso (tricotomia facial, banho com antisséptico, higiene oral).

Outro cuidado do pré-operatório compreende o encaminhamento do paciente ao centro cirúrgico em maca com roupa privativa necessária, com prontuário devidamente preenchido e exames pré-operatórios trazidos pelo paciente.

\subsubsection{FASE INTRAOPERATÓRIA}

Para o ato cirúrgico é necessária caixa de instrumental específico com miniplacas e miniparafusos metálicos para a fixação da mandíbula e/ou maxila, conforme a técnica do cirurgião; estes materiais são consignados devido o alto custo, sendo solicitados com antecedência pelo cirurgião e fornecidos por empresas especializadas no dia anterior ao procedimento cirúrgico.

É fundamental a solicitação com antecedência do material para facilitar a comunicação da enfermagem com os fornecedores, garantir o recebimento na data prevista e processa-lo na central de material com esterilização em tempo hábil para cirurgia.

A fase intraoperatória compreende o período em que o paciente é admitido no centro cirúrgico, encaminhado à sala operatória, submetido ao procedimento anestésico-cirúrgico e, ao término dos procedimentos, encaminhado à sala de recuperação pós-anestésica, onde se inicia o pósoperatório $^{27}$. 
$\mathrm{Na}$ admissão no centro cirúrgico, a enfermeira confere todas as informações registradas no prontuário do paciente, e tranquiliza-o enquanto aguarda a chegada da equipe cirúrgica.

Os exames de imagem são dispostos no negatoscópio da sala operatória e o guia cirúrgico deve ser encaminhada para a termodesinfecção antes de iniciado o procedimento cirúrgico.

O procedimento cirúrgico compreende um período de duas a seis horas de duração e sua variação se deve ao tipo de técnica cirúrgica empregada. É realizado sob anestesia geral com intubação nasotraqueal; os olhos são devidamente lubrificados com gel lacrimal artificial e as pálpebras ocluídas; a antibioticoterapia profilática e o corticoide devem ser administrados na indução anestésica; o posicionamento cirúrgico aplicado é o dorsal com elevação de cabeceira ${ }^{28 .}$

Alguns anestesiologistas recomendam a indução de hipotensão arterial durante o ato cirúrgico. Um estudo de Grando et al. ${ }^{29}$ concluiu que a técnica de indução com a hipotensão arterial mostrou-se eficaz e segura com diminuição da perda sanguínea, com mínimas complicações e não determinando a necessidade de transfusão de sangue alogênico no intraoperatório.

A via de acesso cirúrgico atualmente utilizada é intraoral. Para evitar deglutição ou aspiração de sangue no intraoperatório, é realizado um tamponamento de orofaringe com compressas de gaze e retirado ao término do procedimento. As técnicas cirúrgicas são descritas adiante.

Na sala cirúrgica cabe à enfermagem participar do ato anestésico, auxiliar no posicionamento cirúrgico, prevenindo lesões de pele por posicionamento e prevenir a ocorrência de hipotermia, utilizando cobertores e/ou aquecedores ${ }^{18 .}$

Em procedimentos cirúrgicos com duração superior a duas horas, são requeridas medidas para a prevenção de trombose venosa por meio de 
enfaixamento de membros inferiores ou colocação de meia elástica, além de sondagem vesical de demora para melhor controle da perda de fluidos.

Algumas complicações que podem ocorrer durante este período geralmente são resultantes de atos do cirurgião e do anestesista.

A ruptura do tubo endotraqueal durante o procedimento cirúrgico por corte acidental do cirurgião foi descrita em dois estudos, um realizado em Nova York e outro realizado em Baltimore ${ }^{30,31}$. Esta intercorrência, além de prolongar o tempo cirúrgico devido ao tempo exigido na recuperação da manutenção da via aérea do paciente, pode ainda causar estresse na equipe e levar o paciente a inúmeras complicações por hipóxia.

O sangramento transoperatório é uma consequência inevitável da cirurgia e pode ter origem por rompimento de vasos sanguíneos ou por problemas de hemostasia. Hemorragias venosas são tratadas com tamponamento sob pressão e/ou uso de hemostáticos, enquanto hemorragias arteriais com ligadura dos vasos e/ou eletrocoagulação ${ }^{21}$.

No entanto, níveis de sangramento ultrapassados, indicam uma situação de perigo e preocupação. Um estudo realizado em Porto Alegre aferiu uma perda sanguínea significativa nas cirurgias ortognáticas, atingindo em média $1200 \mathrm{ml}$. Nesse caso, recomenda-se avaliar a possibilidade de reposição volêmica com cristaloides, coloides, preservação de hemácias, transfusão sanguínea ou autotransfusão ${ }^{32}$.

Outra complicação possível é a fratura indesejável de mandíbula e maxila durante a manipulação das estruturas. Este tipo de transtorno aumenta o tempo cirúrgico e requer a reparação com reposicionamento e fixação rígida. Quando há fratura de maxila, uma consequência grave pode ser a amaurose, que pode ocorrer por fragmentos da maxila que traumatizam o nervo óptico, por compressão por edema e/ou hematoma local ${ }^{21,33}$.

Além de fraturas ósseas, é possível que lesões dentárias ou de raízes dentárias, tais como: odontosecção por broca ${ }^{34,35}$, doença periodontal ${ }^{34}$, 
lesões osteoliticas ${ }^{34,36,37}$, absorção radicular $^{34}$, defeito angular ${ }^{34}$, hipersensibilidade de bulbo dental ${ }^{38}$, deslocamento da linha média dentária $^{38}$, dente molar removido erroneamente ${ }^{38}$ estejam entre as complicações. O risco de lesões dentárias pode ser minimizado pelo planejamento cuidadoso durante o pré-operatório. Brocas e serras adequadas podem auxiliar durante a osteotomia, prevenindo a lesão dentária ${ }^{39}$

As injúrias nervosas podem ser classificadas em injúrias aos nervos sensitivos e injúrias aos nervos motores, decorrentes de excessiva força aplicada aos nervos pelos afastadores, traumas de descolamento periosteal da face medial do ramo, das osteotomias realizadas com brocas e serras, cinzelamento durante a fratura sagital, compressão do nervo após fixação, alteração da posição anatômica do nervo e lesão indireta causada por edema ou hematoma local. A prevenção, como sempre, consiste num planejamento cuidadoso e num profundo conhecimento da anatomia ${ }^{20,21 .}$

Durante o intraoperatório, os tecidos moles são bastante manipulados, o que leva ao edema da região. A fragilidade do tecido pode facilitar lacerações pela broca cirúrgica ou instrumentais ${ }^{37,38,40}$. Quando estas lesões são pequenas podem fechar espontaneamente, quando maiores requerem intervenção cirúrgica ${ }^{39}$.

Ao término do procedimento cirúrgico, a enfermeira deve auxiliar na extubação e transferência do paciente da mesa cirúrgica para a maca, elevando a cabeceira da maca a trinta graus, e encaminhá-lo à unidade de recuperação pós-operatória.

\subsubsection{FASE PÓS-OPERATÓRIA}

A próxima fase do processo é o pós-operatório e tem início quando o paciente deixa a sala de cirurgia e é encaminhado para a sala de recuperação pós-anestésica e posteriormente à unidade de internação. $A$ assistência de enfermagem a pacientes no período pós-anestésico deve ter como objetivo garantir uma recuperação segura, prevenindo, detectando e 
atendendo as complicações que possam advir do procedimento anestésicocirúrgico ${ }^{41 .}$

No pós-operatório imediato, cabe à enfermagem atenção à via aérea do paciente, que pode ser obstruída pelo edema causado pelo procedimento cirúrgico. A oximetria (saturação de oxigenação sanguínea) deve ser rigorosamente analisada detectando precocemente a hipóxia. A cabeceira da cama deve ser mantida elevada para promover maior permeabilidade de vias aéreas ${ }^{24}$.

Deve-se ter atenção aos cuidados com sangramento nasal e oral, secreções orais, cianose, sinais de isquemia da área operada, e o ressecamento dos lábios. O paciente pode referir parestesia na região operada, que é normal após o procedimento.

Encaminhado o paciente à unidade de internação, esta fase de pósoperatório requer uma assistência específica, contínua e qualificada. Neste momento, a visita pós-operatória de enfermagem promove a orientação e educação do paciente acerca de sua recuperação e retomada de suas atividades rotineiras ${ }^{25}$.

A avaliação do paciente após a cirurgia deve levar em consideração a dificuldade em realizar funções do sistema estomatognático (conjunto de estruturas orais que desenvolvem funções comuns, tais como, sucção, mastigação, deglutição, fonação e respiração) devido ao edema, dificuldade imposta pela fixação intermaxilar e pelo comprometimento nervoso tanto da sensibilidade quanto da motricidade estão acometidas nas estruturas envolvidas em tais funções ${ }^{42}$.

Realizada a cirurgia, o cirurgião acompanha o paciente durante todo o pós-operatório, somente encaminhando-o para o ortodontista quando estiver em condições de receber o refinamento ortodôntico. Cabe ao ortodontista finalizar a terapia ortodôntica restabelecendo a oclusão e aperfeiçoando a estética ${ }^{43}$. 
Com a osteossíntese realizada por meio de fixação interna rígida com miniplacas e miniparafusos, o bloqueio mandibulomaxilar pode não ser necessário, sendo utilizados elásticos para contenção oral, mais adequados para a manutenção de vias aéreas e controle do edema ${ }^{28 .}$

As complicações decorrentes do pós-operatório ocorrem imediatamente após o procedimento até alguns meses no pós-operatório. Algumas complicações podem ser decorrentes do intraoperatório, notadas no fim do procedimento cirúrgico ou na recuperação anestésica.

Náuseas e vômitos podem ser decorrentes da anestesia geral, com incidência em 20 a $30 \%$ dos pacientes, estando presentes nas primeiras $24 \mathrm{~h}$ do pós-operatório ${ }^{44}$. Não acometem todos os pacientes, mas curiosamente ocorrem mais em mulheres do que homens. Quando o paciente é submetido a bloqueio mandibulomaxilar, esta complicação torna-se importante pelo risco de broncoaspiração.

Em cirurgia ortognática, o bloqueio do ouvido médio é comum, devido à intubação nasotraqueal, e, particularmente, depois da osteotomia maxilar. Os músculos palatais foram traumatizados e deslocados pela osteotomia, então muitos pacientes reclamam de ouvido "cheio", diminuindo a qualidade dos sons e provocando desconforto ${ }^{20}$.

O edema, apesar de esperado no pós-operatório imediato, devido à manipulação dos tecidos da face, pode se tornar uma complicação importante quando compromete as vias aéreas superiores, impedindo a respiração ou quando não regride após a terceira ou quarta semana de pósoperatório ${ }^{10 .}$

O sangramento pode ocorrer por falta de hemostasia adequada e/ou rompimento de vasos sanguíneos no pós-operatório ${ }^{33}$. Em alguns casos o tamponamento é suficiente até completar a hemostasia, para outros é necessária a reintervenção cirúrgica para sutura adequada. Outra técnica que pode ser empregada é a embolização do vaso sangrante por meio da arteriografia. 
A formação de hematoma tem sido geralmente descrita como um problema pequeno, porém pode se tornar maior quando o hematoma se desenvolve no assoalho da boca, podendo, causar uma obstrução da via aérea, ou quando este ocorre no interior da cavidade orbitária, podendo causar a compressão de estruturas nervosas e do globo ocular ${ }^{36 .}$

Outra complicação ligada aos vasos sanguíneos é a diminuição do fluxo sanguíneo maxilar que pode levar à perda de um segmento. Ocorre quando o sangue fornecido aos segmentos ósseos é interrompido, geralmente por causa dos danos ao tecido palatal ou de vasos sanguíneos que alimentam esses segmentos, levando à necrose do tecido. A necrose vascular pode levar à recessão gengival, à perda óssea periodontal ou à perda total dos dentes ou do osso alveolar ${ }^{45}$.

Uma complicação possível presente na técnica Lefort I é a sinupatia, que varia de uma moderada obstrução nasal, desconforto e dor até situações como dacriocistite, infecções periorbitárias, osteomielite e até trombose do seio cavernoso ${ }^{21 .}$

Alterações neurossensoriais normalmente são percebidas no pósoperatório imediato, sendo resultado da tração do nervo infraorbitário e do trauma direto aos nervos alveolares ântero, médio e póstero-superiores, ao nervo nasopalatino e ao nervo palatino descendente ${ }^{20}$. Um estudo realizado na Universidade da Carolina do Norte mostra que $98 \%$ dos pacientes com quase um mês de pós-operatório apresentavam alteração na sensibilidade no queixo e $81 \%$ destes ainda apresentavam esta alteração por até seis meses de pós-operatório ${ }^{46}$.

Outros estudos relatam a injúria de nervos trigêmeo ${ }^{36}$, mentoal ${ }^{36,47}$, lingual ${ }^{35,36}$, bucal e facial ${ }^{36}$, alveolar inferior ${ }^{35,37,48-52}$, infraorbitário ${ }^{35}$ com sintomas de parestesia e alguns casos com anestesia, que regrediram em até um ano após a cirurgia. Um dos estudos relata que o paciente foi submetido a uma nova intervenção cirúrgica após um ano na tentativa de correção do sintoma de anestesia ${ }^{36 .}$ 
A reabsorção do côndilo pode ocorrer por diferentes forças mecânicas durante o procedimento cirúrgico. Um aumento da carga devido à autorrotação da mandíbula é um dos principais componentes da etiologia da reabsorção condilar progressiva após cirurgias ortognáticas ${ }^{53}$. Com a reabsorção condilar progressiva, pode haver distúrbios na articulação temporomandibular (ATM), mesmo em pacientes que não apresentavam sinais ou sintomas prévios ${ }^{9}$.

A dor pós-operatória é moderada e pode ser controlada por medicação analgésica; também pode estar associada a satisfação ou insatisfação com o resultado da cirurgia ${ }^{9,10}$. Pacientes insatisfeitos com o resultado apresentam quadros álgicos maiores no pós-operatório.

Alguns pacientes podem apresentar quadro de depressão pósoperatória, relacionada a acidentes decorrentes da anestesia geral, ocasionando problemas de fonação pós-intubação traqueal. Outras causas seriam a dificuldade de alimentação, insônia, agitação psicomotora, fadiga, autorreprovação e culpa inapropriada ${ }^{9}$.

Uma consequência inicial do procedimento cirúrgico é a perda de massa corpórea devida à dificuldade de mastigação, edema, dor e parestesia. O paciente é submetido a uma dieta liquida no pós-operatório e que muitas vezes em seu domicilio não é balanceada, acarretando desnutrição e perda de massa corpórea significativa, comprometendo a cicatrização da ferida operatória e aumentando a suscetibilidade para infecção ${ }^{54}$. Um estudo realizado no Hospital Universitário da PUC/RS em Porto Alegre, encontrou perda de 4 a $9 \%$ do peso corpóreo no pósoperatório dos pacientes submetidos a cirurgia ortognática, o que foi considerado pelo autor como uma perda muito significativa ${ }^{55}$.

A recidiva cirúrgica, apesar de incomum pode ser ocorrer, causada pela falta do contato ósseo entre os fragmentos e/ou pela fixação inadequada dos segmentos maxilares em sua nova posição, por infecção local e por reabsorção condilar progressiva assim que a carga condilar estiver estabilizada ${ }^{20,53 .}$ 
As complicações relacionadas ao material rígido de fixação interna incluem desconforto do paciente ${ }^{35,56,57}$, deiscência cirúrgica ${ }^{40,56}$, perda dos parafusos $^{56}$, exposição da placa ${ }^{56}$; problemas mecânicos que resultaram em mobilidade da estrutura óssea ${ }^{58}$; perda da fixação ${ }^{57,59}$, ruptura da placa ${ }^{35,50}$, placa palpável na mucosa oral $^{38}$ e infecção relacionada ao material de fixação ${ }^{56,57}$. Em todos os estudos citados, o material de fixação teve que ser removido.

Infecções cirúrgicas são descritas com índices abaixo de 10\% devido à profilaxia antibiótica ${ }^{21}$. A infecção cirúrgica, quando presente no pósoperatório, pode acarretar obstrução da via aérea, perda de osso e dentes, osteomielite, septicemia, trombose dos seios cavernosos e meningite ${ }^{45}$.

A infecção pode estar relacionada à contaminação do material cirúrgico, do campo operatório ou a patologias pré-existentes que diminuem a cicatrização ou imunidade. Outra causa pode estar relacionada à abertura bucal diminuída que favorece a permanência de alimentos na cavidade oral dificultando a higienização, levando a predisposição da infecção ${ }^{42 .}$

O material cirúrgico deve ser esterilizado e a qualidade do processamento fundamenta a prevenção de infecções por meio da redução ou destruição microbiana nos produtos utilizados ${ }^{60}$. A supervisão do processo é de responsabilidade do enfermeiro, visando garantir a segurança do paciente.

A higiene oral rigorosa pode ser um diferencial no cuidado pósoperatório, uma vez que a incisão cirúrgica é realizada intraoral e a presença de alimentos em cavidade pode predispor a uma infecção. Cabe ao enfermeiro acompanhar a higienização e criar condições para o paciente dar continuidade na execução deste cuidado em seu domicílio ${ }^{24 .}$

Medidas locais como desbridamento, irrigação, remoção do material de osteossíntese, drenagem e antibioticoterapia adequada são suficientes para tratar os quadros infecciosos ${ }^{21 .}$ 
Avaliar o paciente adequadamente no pré-operatório pode prevenir algumas complicações no pós-operatório. Um estudo realizado em Tokyo demonstra a importância de diagnosticar pacientes suscetíveis a Síndrome da Resposta Inflamatória Sistêmica (SIRS) e prevenir precocemente as possíveis complicações cirúrgicas evidentes nesses pacientes. Neste estudo, $27,3 \%$ das complicações cirúrgicas estavam presentes no grupo diagnosticado com SIRS contra $0 \%$ do grupo sem SIRS ${ }^{61 .}$

\subsubsection{TÉCNICAS CIRURGICAS}

A cirurgia ortognática abrange algumas técnicas cirúrgicas e que podem ser combinadas entre si, ou seja, o paciente pode ser submetido a duas técnicas no mesmo procedimento cirúrgico, ou realizar uma delas em um primeiro momento e uma segunda técnica programada posteriormente.

A seguir as técnicas são descritas de forma sucinta com o objetivo de apenas elucidar o leitor para existência das mesmas.

\subsubsection{OSTEOTOMIA SAGITAL BILATERAL DO RAMO MANDIBULAR}

A partir de uma incisão intraoral em mandíbula bilateral, a osteotomia é feita em ângulo de 45 graus de forma sagital, proporcionando a fratura da estrutura e sua mobilização. $O$ afastamento dos nervos deve ser realizado para evitar possíveis lesões ${ }^{62}$.

As bases ósseas são fixadas com miniplacas e miniparafusos presos no cortical vestibular, evitando-se qualquer injúria às estruturas vasculares $\mathrm{e}$ nervosas $^{14}$.

O fato de esta osteotomia ser executada sagitalmente permite que haja possibilidade tanto de avanço como de recuo mandibular, sendo indicada, portanto, para prognatismo e retrognatismo (Figura 3). 

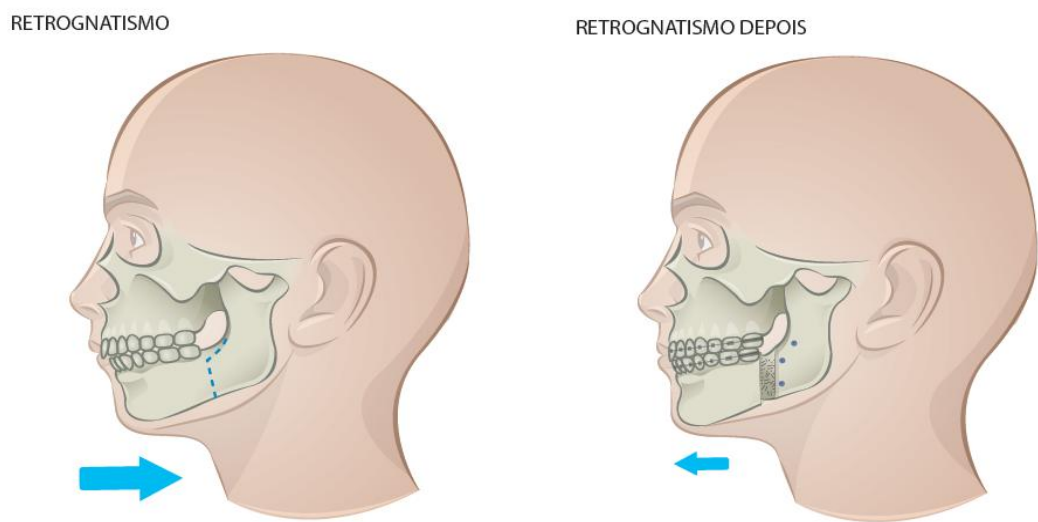

Figura 3 - Paciente com retrognatismo (antes e depois da cirurgia); a linha pontilhada corresponde a região onde foi realizada a osteotomia e, após avanço da mandíbula, a fixação com placa e parafuso.

\subsubsection{OSTEOTOMIA VERTICAL DO RAMO MANDIBULAR}

A incisão é realizada na parte posterior da mandíbula por acesso externo ou interno á cavidade oral, uma serra é utilizada para fratura do osso mandibular e a fixação ocorre com miniplacas e miniparafusos ${ }^{22 .}$

Aplicada principalmente para recuo da mandíbula e indicada para prognatismo (Figura 4). Esta técnica apresenta algumas vantagens em relação à outras técnicas, sendo uma delas a facilidade do procedimento, a redução do tempo da cirurgia e edema pós-operatório, bem como a diminuição do tempo de centro cirúrgico e de hospitalização. Pode haver uma menor incidência de alterações neurossensoriais do nervo alveolar inferior ${ }^{63}$.
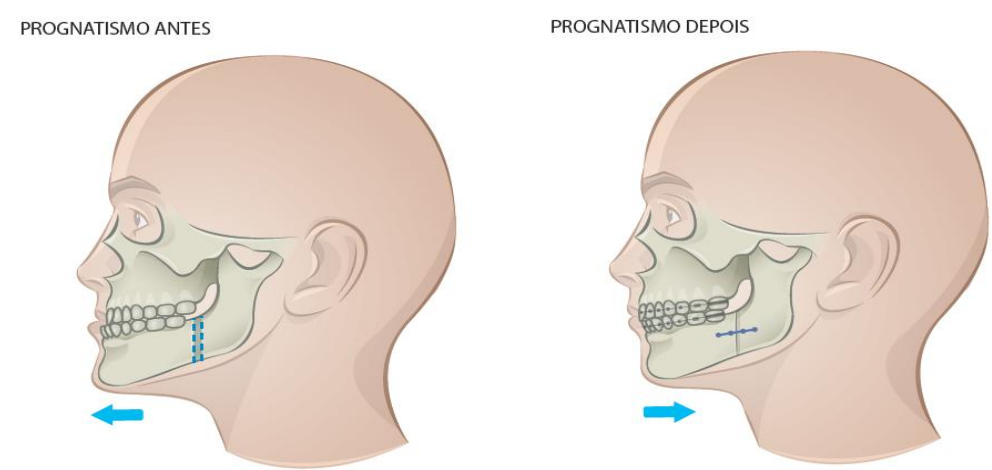

Figura 4 - Paciente com prognatismo (antes e depois da cirurgia); a linha pontilhada corresponde a região onde foi realizada a osteotomia e após recuo da mandíbula a fixação com parafuso. 


\subsubsection{OSTEOTOMIA LEFORT I}

A incisão é realizada no sulco vestibular a partir do primeiro molar em direção a linha média terminando no primeiro molar do lado oposto. A parte óssea é exposta e é realizada a fratura Lefort I com uma lâmina de serra, a maxila é mobilizada ao posicionamento correto, fixada temporariamente com elásticos ou fio de aço até ser confirmado o posicionamento da arcada dentária em relação ao crânio (Figura 5). Este feito, a maxila é fixada com miniplacas e miniparafusos ${ }^{14,22}$.

Esta técnica permite a soltura da maxila e sua total movimentação, respeitando as limitações de cada caso, que podem ser anomalias transversas, anteroposteriores e verticais da maxila. Suas indicações são tanto para o recuo da maxila como para seu avanço, ou mesmo para o aumento de sua dimensão vertical ${ }^{64 .}$
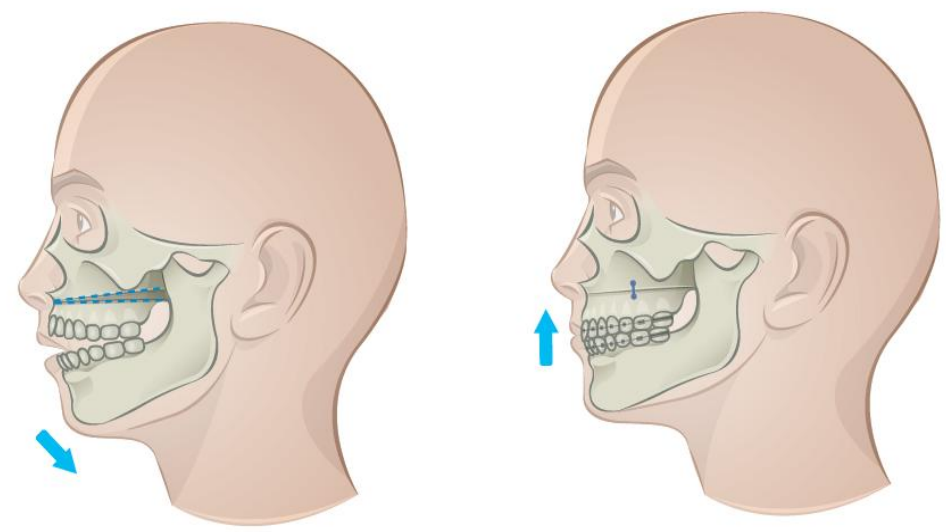

Figura 5 - Paciente com mordida aberta (antes e mordida aberta corrigida após a cirurgia); a linha pontilhada corresponde a região onde foi realizada a osteotomia, região que abrange toda a maxila; a movimentação da maxila é realizada e após sua adequação é realizada a fixação com placas e parafusos

\subsubsection{OSTEOTOMIA COMBINADA}

Consiste no emprego das duas técnicas citadas anteriormente (osteotomia ramo sagital e osteotomia Lefort I) (Figura 6 - A). Após as incisões é realizada a colocação da goteira (splint), verificado o 
posicionamento correto dos maxilares e feita a fixação com miniplacas e miniparafusos 22 .

Pacientes de face longa ou mordida aberta esquelética geralmente são tratados com cirurgia combinada da maxila e mandíbula, indicada também para casos de assimetria facial por hipoplasia ou hiperplasia condilar, hipertrofia hemifacial e assimetrias mistas maxilomandibulares ${ }^{12}$ (Figura $\left.6-\mathrm{B}\right)$.

Alguns cirurgiões complementam a técnica com a realização de mentoplastia, melhorando a estética facial.

(A)

MORDIDA ASSIMÉTRICA ANTES

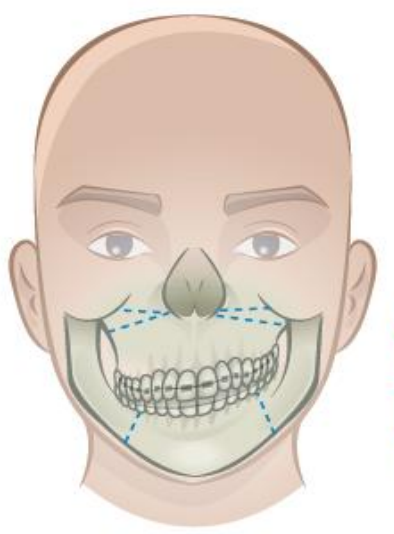

A)
MORDIDA ASSIMÉTRICA DEPOIS

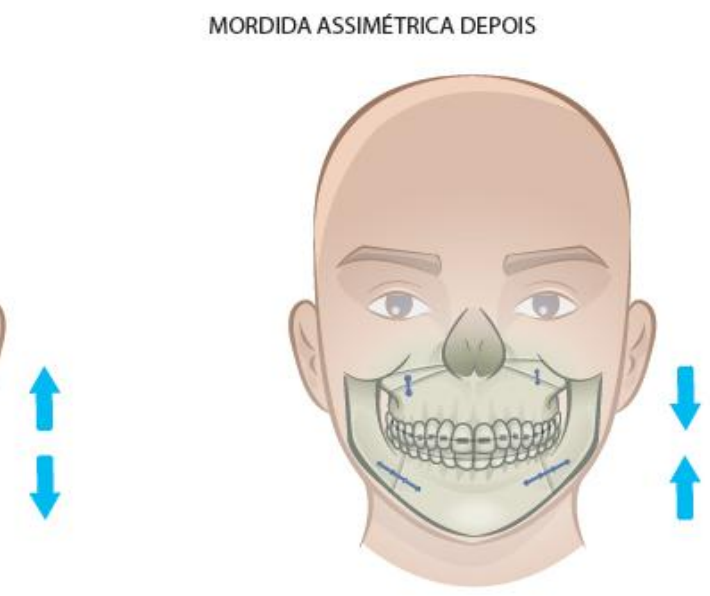

(B)

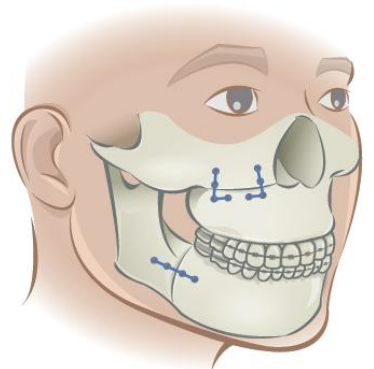

Figura 6 - (A) Paciente após cirurgia ortognática combinada (procedimento em maxila e mandíbula), fixação da área operada com placa e parafuso. (B) Paciente com assimetria facial (antes e depois da cirurgia); linha pontilhada representa a região da osteotomia e, após movimentação da maxila e mandíbula, a fixação com placa e parafuso. 


\subsubsection{DISJUNÇÃO MAXILAR}

Consiste na expansão da maxila e está indicada para pacientes com mordida cruzada de origem esquelética (atresia maxilar) (Figura 7). A técnica foi reconhecida após estudos de Hass com aplicação do aparelho de expansão ${ }^{65}$.

O aparelho de expansão rápida baseia-se no protótipo anunciado por Hass, com ancoragem muco-dento-suportada. Está constituído por uma estrutura metálica rígida, construída com fio 1,2 mm de espessura, e apoio de resina acrílica justaposto à mucosa palatina ${ }^{66}$.

O parafuso, elemento ativo do aparelho, imerge na porção acrílica, no centro sagital da estrutura metálica, unindo as duas metades do aparelho. Os parafusos proporcionam uma expansão de 0,8 a $1 \mathrm{~mm}$ cada volta completa, dividida em quartos de volta ${ }^{66}$.

Este parafuso, quando ativado, acumula força suficiente para romper a resistência oferecida pela referida sutura e pelas suturas pterigopalatina, frontomaxilar, nasomaxilar e zigomático-maxilar após osteotomia executada $^{67}$
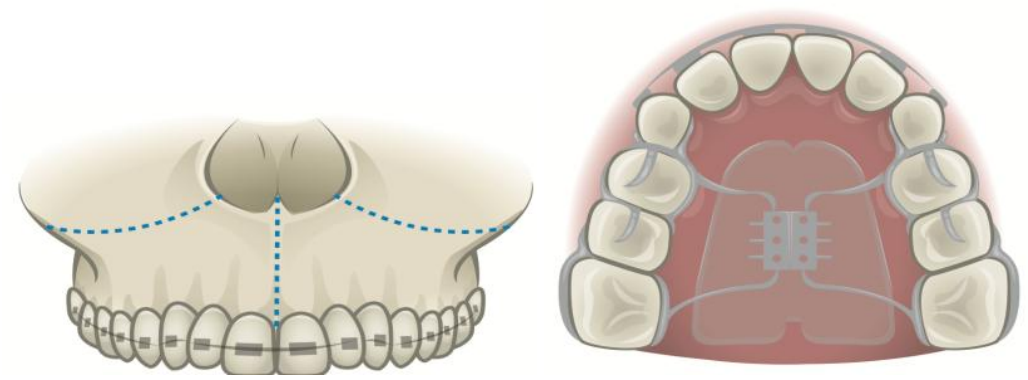

Figura 7 - Disjunção maxilar. Maxila com linha pontilhada representa a região da osteotomia e após osteotomia a colocação do aparelho Hass que irá fazer o prolongamento ósseo de forma lenta.

\subsubsection{MENTOPLASTIA}

A técnica de aumento ou diminuição do mento consiste na osteotomia (com ou sem enxerto) ou implantes aloplásticos. A osteotomia deverá ser 
realizada abaixo dos ápices dentários de forma horizontal ou inclinada e assimétrica, de acordo com o planejamento ${ }^{68}$ (Figura 8).

Está indicado para deformidades que acometem o mento (microgenia ou promentonismo), geralmente estão ligadas a deformidades dentofaciais ${ }^{68}$.

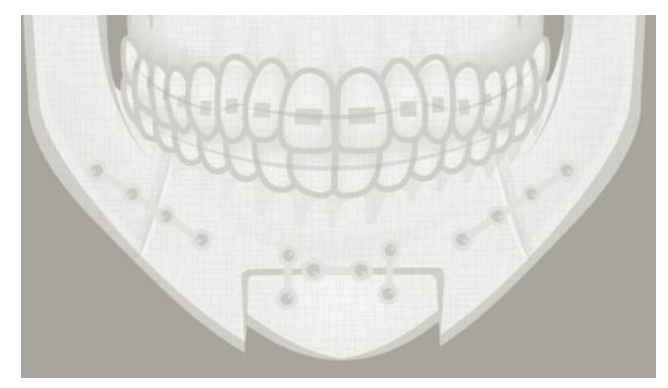

Figura 8 - Mentoplastia para promentonismo combinada com osteotomia de mandíbula. A região do mento após osteotomia foi fixada com placa e parafuso.

Visto que a deformidade facial está presente de forma significativa na população e conhecida a complexidade de cirurgia ortognática, pelo longo percurso do tratamento, as possíveis complicações e as variações de técnicas cirúrgicas, pode-se dizer que é necessário conhecimento amplo da equipe que assiste este paciente.

Em uma equipe multiprofissional, a atuação da enfermeira está representada pelos cuidados e orientação ao paciente. Pode a orientação ter como estratégia auxiliar a aplicação de um material educativo.

Nesta pesquisa é apresentada a trajetória para construção e validação de um material educativo para pacientes de cirurgia ortognática. 


\section{OBJETIVO}

\subsection{OBJETIVO GERAL}

Elaborar e validar um material educativo para pacientes submetidos à cirurgia ortognática com relação aos cuidados pós-operatórios.

\subsection{OBJETIVOS ESPECÍFICOS}

1. Preparar um material educativo com orientação sobre cuidados pós-operatórios da cirurgia ortognática

2. Avaliar junto à equipe multiprofissional a pertinência das informações concebidas no material educativo.

3. Avaliar junto aos pacientes a clareza das informações concebidas no material educativo. 


\section{REVISÃO DE LITERATURA}

\subsection{EDUCAÇÃO PÓS OPERATÓRIA}

A educação em saúde é uma estratégia direcionada para as ações básicas de promoção, prevenção, cura e reabilitação. No Brasil, a educação em saúde tem dois pressupostos. O primeiro refere-se às medidas preventivas e curativas que visam à obtenção da saúde e o enfrentamento das doenças; o segundo, às estratégias da promoção da saúde como construção social da saúde e do bem-estar ${ }^{69}$.

As práticas educativas têm como objetivo criar condições para que a educação dos indivíduos e grupos se viabilizem na melhoria da saúde da população. Estas práticas estão presentes desde tempos remotos, quando a maioria da população buscava a medicina popular para resolver seus problemas de saúde ${ }^{70}$.

A educação em saúde assume um papel fundamental no processo do cuidar em enfermagem. Os cuidados prestados pela enfermagem requerem muito mais do que uma simples habilidade técnica, necessitam que os profissionais desempenhem uma prática comprometida com a saúde da população sob a ótica da promoção da saúde e prevenção de agravos ${ }^{71}$.

O objetivo de educar o paciente inclui fornecer informação e apoio, corrigir conceitos errôneos e ajudar o paciente a compreender papéis e responsabilidades de autocuidado ${ }^{72}$. As vantagens da educação em saúde para o paciente no perioperatório envolvem acelerar a recuperação, análise da ansiedade vivenciada no período, aumento da autoestima ao aumentar a autoeficácia, diminuição de custos hospitalares e redução da dor e queixas do cuidado de saúde ${ }^{73 .}$

Os enfermeiros brasileiros têm se utilizado desta possibilidade na sua prática profissional cotidiana, seja por meio de práticas educativas 
desenvolvidas nas atividades diárias de trabalho, nos mais variados contextos do cuidado, seja em programas voltados para o ensino às pessoas de quem cuidam ${ }^{69}$.

Está inserido no "ser-enfermeira" o interesse em ajudar os pacientes e suas famílias a aprender como manter e/ou restaurar a saúde e se adaptar às novas condições de seu estado, como por exemplo, a recuperar-se do processo operatório ${ }^{71}$.

A atividade educativa do enfermeiro cirúrgico tem a sua origem no século XIX e tem sido utilizada para proporcionar cuidados seguros, de qualidade, com boa relação de custo/benefício ${ }^{73}$. Em vários estudos, os enfermeiros perceberam que as complicações pós-operatórias poderiam ser minimizadas ou evitadas com o desenvolvimento de um processo educativo voltado para o paciente durante o período perioperatório ${ }^{74}$.

Na prática profissional observa-se que as ações do enfermeiro têm se desenvolvido muito mais como uma orientação sobre normas e rotinas, explicitando, por exemplo, o momento em que o paciente será encaminhado ao centro cirúrgico, quanto tempo em média leva o procedimento cirúrgico, como será o retorno e quais as rotinas determinadas para o fluxo cirúrgico e não direcionadas para os cuidados necessários para a recuperação do paciente. Na maioria das vezes, estas orientações fragmentadas, repetitivas e impostas sobre o paciente que recebe informações unilaterais não contribuem para o atendimento de suas necessidades.

O período pós-operatório compreende o período mais longo do perioperatório e é quando o paciente necessita compreender melhor a educação sobre o autocuidado para seguir com as orientações em seu domicílio, pois cada vez mais cedo o paciente recebe alta hospitalar e completa o seu período pós-operatório em casa.

Avaliar as condições de aprendizagem do paciente é uma das atividades mais importantes para a enfermeira de perioperatório. As necessidades dos pacientes relacionadas ao aprendizado sobre sua saúde são diferentes: nem todos os pacientes precisam ou querem saber tudo. A 
maioria dos pacientes precisa saber o bastante para autorizar procedimentos invasivos, facilitar a cooperação intraoperatória; realizar o autocuidado no domicílio e sobreviver até que mais sessões de ensino possam ser proporcionadas $^{73}$.

A avaliação das condições que permitem uma alta precoce nem sempre considera o nível de preparo, as orientações recebidas e a compreensão dessas informações. A maioria das informações é ministrada de forma reiterativa, fragmentada, pelos vários tipos de profissionais que valorizam de maneira diferente cada cuidado ${ }^{75}$.

Um estudo de Silva ${ }^{76}$, realizado na cidade de São José dos Campos/SP, indagou aos pacientes sobre a adequação das orientações pós-operatórias. Constatou-se que $55,4 \%$ dos respondentes consideraram as orientações parcialmente suficientes, $35,7 \%$ suficientes e $8,9 \%$ insuficientes. A justificativa apresentada por aqueles que não consideraram as orientações suficientes foram o pouco tempo para assimilação das mesmas.

Nesse mesmo estudo, um dos motivos para insatisfação do atendimento perioperatório foi a ausência de orientações por escrito para facilitar a compreensão e a consulta no caso de dúvidas. Dentre as queixas sobre a assistência perioperatória, $60 \%$ delas referem-se à falta de orientação quanto à ferida operatória, relacionadas ora à ausência desta orientação ora à sua não compreensão.

As necessidades de aprendizagem de pacientes no período perioperatório configuram uma oportunidade da enfermeira dispensar-Ihes ensinamentos para o enfrentamento do medo, da ansiedade e mesmo da dor $^{69}$. Educar em saúde, nestas situações, contribui para a redução dos riscos de complicações pós-operatórias, oferecendo, de certo modo, ao paciente controle da situação em relação aos acontecimentos do ato operatório e do período após esse evento.

Com a possibilidade de alta no mesmo dia ou no dia seguinte da intervenção cirúrgica, a enfermeira deve iniciar o planejamento de alta logo 
no inicio do pré-operatório e garantir que o paciente esteja pronto para o autocuidado ou que recursos médicos, financeiros ou sociais serão necessários para auxiliar sua recuperação ${ }^{73}$.

O ensino do paciente cirúrgico é compreendido como o processo de desenvolvimento de habilidades com as quais ele pode ter favorecida a sua reabilitação à cirurgia ${ }^{74}$. Esta ação é uma das prioridades de promoção de saúde descritas na Carta de Ottawa ${ }^{77 .}$

Um dos objetivos da assistência de enfermagem é levar o paciente a participar dos esquemas terapêuticos. Essa participação depende dos processos de comunicação, a partir dos quais se estabelecem as relações de confiança necessárias para o paciente diminuir o medo, a ansiedade e permitir à pessoa fragilizada pela doença lutar por seu restabelecimento com dignidade ${ }^{78}$

A comunicação entre os profissionais de saúde e pacientes é inerentemente problemática. Profissionais querem se comunicar com clareza, mas tendem a usar a terminologia técnica porque é preciso, é familiar e, muitas vezes, porque não há palavras exatamente equivalentes em termos não técnicos disponíveis. Além disso, há uma tendência em oferecer mais informação do que os pacientes podem processar. Mesmo os pacientes com melhor compreensão apresentam dificuldades para processar informação médica, porque não estão familiarizados com a terminologia médica e estão ansiosos e preocupados com seus sintomas, o que torna difícil a concentração ${ }^{79}$.

Kessels $^{80}$ afirma que 40 a $80 \%$ das informações fornecidas pelo profissional de saúde ao paciente são esquecidas após alta hospitalar. E quanto maior a quantidade de informação mais informações são esquecidas. O mesmo autor refere que a metade da informação é lembrada de forma incorreta ou porque as informações são passadas com terminologia médica, ou porque o meio de informação oferecido (falado/escrito) é inadequado, ou pela baixa escolaridade e/ou compreensão do paciente. 
A comunicação é um instrumento básico do cuidado e não deve estar restrito apenas à troca de mensagens entre enfermeiro e pacientes. Outros meios de comunicação (sonoro, escrito, audiovisual, multimídia) devem ser empregados para que haja facilitação do processo de entendimento do paciente. A comunicação deve ser vista como um instrumento de ajuda terapêutica.

Embora as práticas de produção de materiais educativos/informativos dirigidos aos pacientes sejam universalmente difundidas, o seu processo de produção por parte das instituições que produzem conhecimento em ciências da saúde é raramente descrito, produzindo resultados insatisfatórios, pela ausência de método ${ }^{81}$.

Nota-se em comunidades virtuais e blogs uma crescente demanda de pacientes em busca de informações sobre o período perioperatório da cirurgia ortognática. Esses pacientes trocam informações sobre cuidados pós-operatórios com outros pacientes, ou seja, transmitem informações sem embasamento científico. Isso pode aumentar a possibilidade de complicações cirúrgicas.

Araújo et al. ${ }^{13}$ elaboraram o "Manual de orientação aos pacientes com vistas à cirurgia ortognática" com a intenção de ter um método de apresentação eficiente, esquemático, de fácil manuseio, contendo todas as informações pertinentes ao tratamento ortodôntico-cirúrgico, mas que é disponibilizado apenas para a equipe cirúrgica, com o intuito de orientá-los sobre como proceder com este paciente.

Não havendo estudos sobre a orientação pós-operatória para este tipo de paciente, e tendo em vista a necessidade dos pacientes de uma orientação por escrito, este estudo tem por finalidade elaborar um material educativo para subsidiar as orientações fornecidas ao paciente no pósoperatório de cirurgia ortognática, de modo que ele tenha em mãos um material com informações claras, que supram sua necessidade de ir buscálas nos blogs e comunidades da internet. 
Pode-se dizer que a orientação reforçada por um material educativo produzido para esta finalidade é um diferencial no cuidado da enfermagem perioperatória, desenvolvendo-se um atendimento perioperatório especializado e estendido ao cuidado domiciliar por meio de orientação pósoperatória.

\subsection{MATERIAL EDUCATIVO}

Embora existam excelentes razões para os enfermeiros estarem envolvidos em todos os aspectos do desenvolvimento de material educativo para pacientes, a maioria deles nunca foi ensinada a construir um material educativo $^{82}$

Mais de 23 milhões de adultos norte-americanos não podem compreender as instruções ou materiais fornecidos pelos prestadores de cuidados de saúde. Esses adultos são analfabetos funcionais. Não é fácil identificá-los, eles podem ser pobres ou ricos e podem ter completado qualquer nível de escolaridade ${ }^{83}$. No Brasil, o índice de analfabetismo funcional se aproxima dos $27 \%$, segundo o Censo $2000^{84}$.

Complicações sérias podem resultar da incapacidade de um paciente para compreender e agir sobre instruções impressas no material educativo, desde efeitos colaterais significativos de um tratamento ou medicação, até cuidados com curativos e recomendações de repouso. Tais complicações seriam totalmente evitáveis, se o paciente fosse capaz de ler e entender as instruções $^{85}$.

Outro fator para a baixa compreensão das informações é o fato de que imigrantes apresentam uma barreira de linguagem durante a comunicação verbal/escrita. Quando não compreendem bem o idioma não conseguem atender as solicitações ou seguir corretamente as orientações ${ }^{86 .}$

Compreender a existência de pessoas com dificuldade na interpretação de texto é crucial quando se escreve para pacientes. Embora não seja explícito o pouco conhecimento em leitura e compreensão de texto, 
é vital que o paciente compreenda as informações fornecidas para conseguir gerir melhor sua própria saúde ${ }^{87 .}$

Uma solução para este problema é escrever um material educativo a partir da capacidade de compreensão do paciente. Isso não quer dizer que a escrita de fácil leitura é aquela aplicada para crianças (isso seria humilhante para os adultos), mas sim uma escrita compreensível a pessoas com seis anos de estudos ${ }^{82}$

Antes de iniciar o desenvolvimento ou processo de revisão de um material educativo deve-se definir o objetivo ou finalidade e identificar o público alvo. $O$ objetivo determinará quais informações serão incluídas no texto e se ilustrações devem ser usadas para facilitar a compreensão ${ }^{88 .}$

Para conhecer o público alvo, um estudo realizado em Chicago aplicou a técnica de grupo focal, questionou sobre informações recebidas anteriormente e o que os pacientes desejavam em um material educativo, e obteve como resposta que eles desejavam mais informações sobre sua doença do que as recebidas na consulta com o médico. Eles procuravam respostas para as suas questões no momento em que formulavam as perguntas, e isto ocorre após a visita do profissional de saúde. Embora existam inúmeras fontes de informações (livros, internet, grupos) preferem receber materiais educativos do seu profissional de saúde ${ }^{89}$.

Para iniciar a construção de um material educativo, todos os interessados, incluindo pacientes, devem estar envolvidos, pois isto garante que o material atenda às necessidades dos pacientes. As características que devem ser levadas em consideração na concepção de material educativo podem ser agrupadas nas seguintes categorias: conteúdo, linguagem, organização, leiaute e tipografia, ilustrações, aprendizagem e motivação $0^{87,90 .}$

Construído o material educativo, a validação deste junto ao paciente é necessária para averiguar a sua adequação e funciona como um feedback, antes de sua distribuição ${ }^{91}$. $O$ paciente deve compreender o texto e as imagens ali contidas, caso contrário o material perde sua função, pois o 
paciente abandona a leitura, o que pode interferir nas orientações sobre os cuidados importantes para sua recuperação.

\subsubsection{CONTEÚDO}

A intenção do material educativo bem como o objetivo devem estar claros para o leitor. Se a proposta não for clara, o paciente pode deixar de prestar atenção no material ${ }^{90}$. A proposta do conteúdo é informar o que o paciente precisa saber e não o que seria bom ele saber, mas é difícil fazer esta distinção ${ }^{87}$.

Quanto à escrita, é recomendado o uso de palavras curtas com três sílabas e frases com 10 a 15 palavras, e cada parágrafo deve se referir a apenas uma informação, pois sentenças longas podem dificultar a compreensão. Para a terminologia médica é necessário encontrar palavras substitutas; quando não houver, buscar explicar o significado das palavras. Apesar de uma leitura facilitada, alguns pacientes não compreendem o texto e a aplicação de imagens pode elucidar o leitor e facilitar a compreensão ${ }^{88,91-}$ 94.

O texto deve ser escrito como se fala com o paciente, usando por exemplo, pronomes "eu" e "você", aplicando a voz ativa na escrita para criar proximidade com o leitor, como por exemplo, "a enfermeira vai enfaixar seu braço". No decorrer do texto, é necessário interagir com o leitor para facilitar a leitura e construir uma lembrança sobre a informação escrita, assim como exemplificar situações para familiarização do paciente p2-94. $^{9}$

Sugere-se escrever com o foco no gerenciamento da situação específica, seja um procedimento, uma instrução para cirurgia ou um autocuidado. O ideal é que o paciente entenda da melhor forma possível como vai ser o procedimento e como proceder. Se a instrução requer alguma atividade é recomendado que esta seja colocada passo a passo e com ilustrações de cada fase, como por exemplo, "usar um inalador: 1) quando usar o inalador; 2) sentar-se ou ficar em pé; 3) anexar o tubo espaçador; 4) expire..." 87. 
Não se devem usar frases negativas para uma ação. Se a intenção é não recomendar uma atividade, a mesma deve ser colocada de forma afirmativa na frase, por exemplo, "para reduzir o risco de acidente vascular cerebral, você vai precisar fazer alterações no que você come" 90,94 .

\subsubsection{ORGANIZAÇÃO}

A maneira como o material educativo é organizado pode afetar como a informação é entendida, compreendida e mantida ${ }^{94}$. As informações consideradas mais importantes devem ser apresentadas primeiramente. $O$ arranjo do texto deve seguir uma lógica. Alguns leitores preferem instruções passo a passo, outros uma abordagem generalizada e de fácil compreensão 92 .

É imprescindível a utilização de subtítulos, para que os leitores encontrem rapidamente as respostas às suas perguntas. $O$ emprego de palavras chave pode ser um diferencial e devem ser colocadas em destaque, pois muitos leitores leem apenas o destaque ou subtítulo da mensagem. Destacar, então, palavras chave pode chamar a atenção do leitor para o texto. A aplicação do formato pergunta e resposta também pode ser útil, uma vez que transmite a informação com clareza ${ }^{94 .}$

Materiais educativos devem ser sucintos. No caso do material educativo ser extenso, um índice é recomendado para posicionar o leitor e aumentar sua adesão à leitura. Um resumo dos pontos principais no final do documento pode ser útil para reforçar a orientação 90.

\subsubsection{LEIAUTE E TIPOGRAFIA}

É importante utilizar cores atraentes para chamar a atenção do leitor. Entretanto, não se pode esquecer que alguns indivíduos não podem diferenciar verde de vermelho devido à doença daltonismo ${ }^{88}$

O formato do material e a apresentação facilitam a identificação e chamam a atenção do leitor para receber o material e despertar o interesse para a leitura. Apesar de profissionais de saúde descartarem a importância 
da aparência do material, este é um fator preponderante para atrair a atenção dos pacientes ${ }^{95}$.

A qualidade do papel pode influenciar o paciente quanto à qualidade e importância da informação. Um material de qualidade também pode ser interpretado como indício de respeito pelo leitor ${ }^{90 .}$

Deve-se equilibrar a utilização de textos, imagens e espaços em branco. Alguns aspectos podem ajudar na construção do material educativo, como o tamanho de letra: tamanho 12 é adequado, mas se o publico é idoso sugere-se um tamanho maior. Para corpo do texto deve-se aplicar a letra Palatino ou Times Roman, para títulos, Arial ou Helvética, pois são mais fáceis de ler. Colocar espaçamento entre as linhas chama a atenção para o texto e reduz a impressão de cheio, o que intimida o paciente ${ }^{87,92 .}$

A cor do texto deve contrastar com o fundo. Sugere-se utilizar letra preta em fundo branco, evitar palavras ou frases em letras maiúsculas, pois passam a impressão de estar gritando e letras em itálico dificultam a leitura. Negrito deve ser usado apenas para separar e destacar partes $88,92,94$.

Números devem ser apresentados em formatos numéricos; quando escritos por extenso são menos compreendidos. Se forem acrescidas imagens, aplicar legendas concisas. Gráficos devem ser evitados, a não ser que sejam realmente necessários, porque muitos pacientes não conseguem compreender informações em gráficos ${ }^{92 .}$

\subsubsection{ILUSTRAÇÕES}

As ilustrações contribuem para o material educativo quando atraem a atenção do paciente e estimulam a leitura do texto ${ }^{79}$. Imagens podem valer por mil palavras, mas devem ser relevantes e melhorar o texto, não desorganizá-10 87.

Um estudo realizado em Michigan com 234 pacientes ofereceu dois tipos de material educativo para pacientes, um com ilustrações e outro somente com texto. Após três dias, o pesquisador entrou em contato com os 
pacientes para averiguar a compreensão e adesão ao material e constatou que os pacientes que receberam material com ilustrações estiveram mais propensos a ler o material e recordar as informações do que aqueles que apenas leram textos ${ }^{96 .}$

Neste mesmo estudo, quando se averiguou a satisfação com o material, $91 \%$ dos pacientes que receberam o material educativo com ilustrações se disseram satisfeitos; aqueles que receberam o material apenas com texto tiveram índice de satisfação de $64 \%{ }^{96 .}$

A imagem muitas vezes pode ser interpretada de várias maneiras. 0 texto que acompanha a imagem geralmente orienta a interpretação, mas algumas pessoas podem ignorar o texto e tentar apenas interpretar as ilustrações. Com isso, é necessário colocar legenda nas ilustrações para garantir que a compreensão seja adequada ${ }^{79}$.

\subsubsection{APRENDIZAGEM E MOTIVAÇÃO}

A motivação para a leitura leva à aprendizagem do conteúdo e ambas- motivação e aprendizagem- estão diretamente relacionadas com a construção do material educativo. Materiais educacionais bem estruturados aumentam a motivação para seguir o tratamento. Um material bem organizado é mais significativo e efetivo, colocando a informação aos poucos, conforme a adesão do paciente ${ }^{73 .}$

Um texto com linguagem de fácil compreensão, sem termos médicos, com frases curtas e propondo uma interação com o leitor, ilustrações pertinentes e bem colocadas na composição do texto, e conteúdo que responda às questões dos pacientes e que seja apropriado à sua cultura são fatores de motivação e consequentemente levam à adesão ao cuidado e à aprendizagem ${ }^{73,94,97}$. 


\section{TRAJETÓRIA METODOLÓGICA}

Tipo de estudo: estudo metodológico baseado em revisão de literatura e obtenção de informações junto a pacientes, equipe multidisciplinar e ambientes virtuais para elaboração de um material educativo para pacientes de cirurgia ortognática.

Para a elaboração do material julgou-se pertinente conhecer quais as possíveis complicações da cirurgia ortognática e quais as necessidades de informação dos pacientes sobre o assunto.

Desta forma a trajetória metodológica envolveu as seguintes fases: 1) revisão de literatura sobre complicações relacionadas à cirurgia ortognática; 2) busca na Internet de blogs de pacientes submetidos a cirurgia ortognática; 3) grupo focal para levantamento das necessidades de educação perioperatória dos pacientes submetidos a cirurgia ortognática; 4) elaboração do material educativo e validação do conteúdo técnico junto a juízes; 5) validação da clareza de conteúdo junto aos pacientes.

A trajetória metodológica é apresentada em um mapa conceitual na Figura 9.

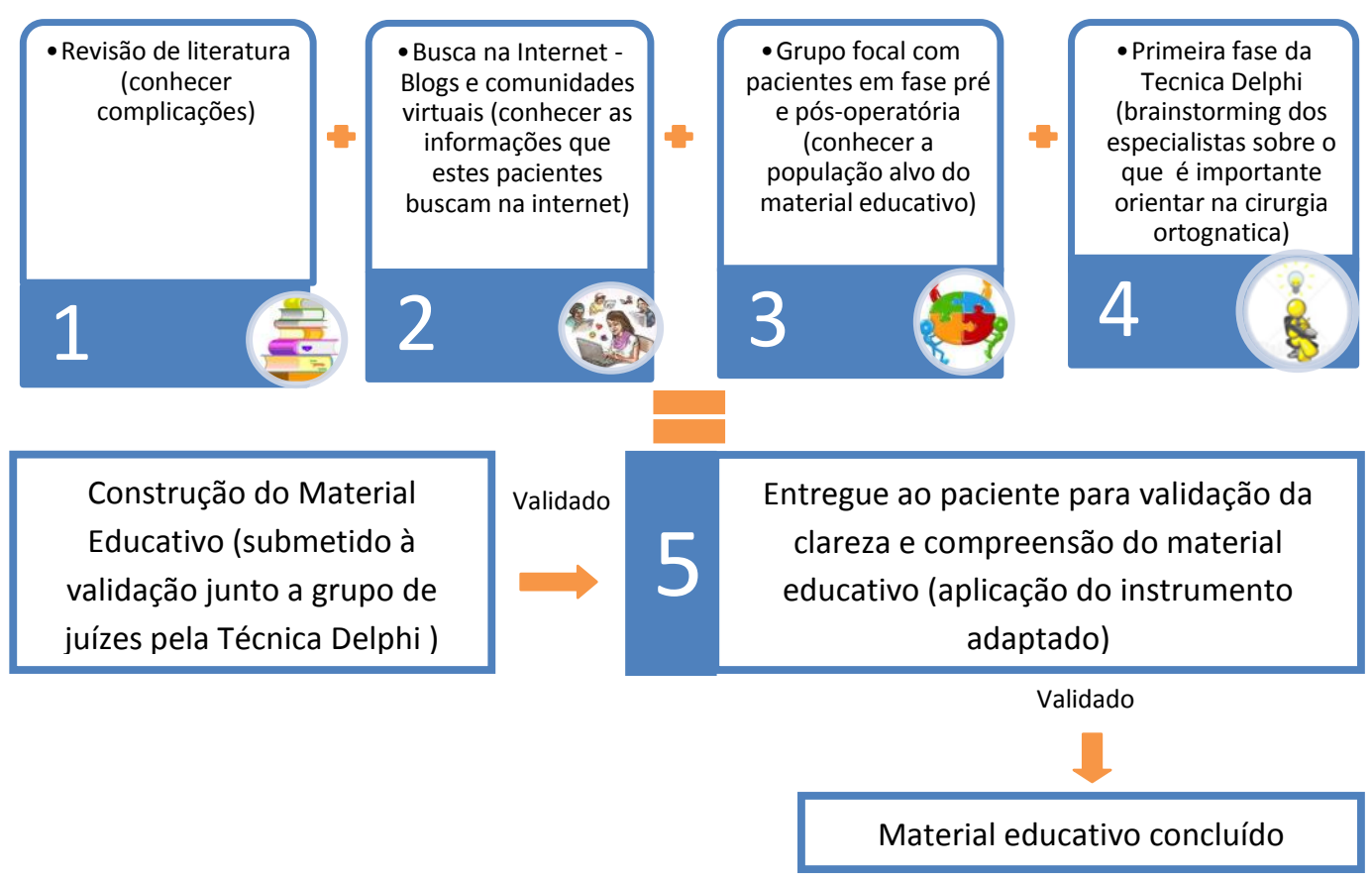

Figura 9 - Mapa conceitual da metodologia aplicada nesta pesquisa 


\subsection{ASPECTOS ÉTICOS}

O projeto de pesquisa foi aprovado pelo Comitê de Ética e Pesquisa da Escola de Enfermagem da Universidade de São Paulo, credenciado no Conselho Nacional de Ética em Pesquisa (Anexo I).

Para a coleta de dados junto aos pacientes foi solicitada autorização aos responsáveis pelo consultório de cirurgia e traumatologia bucomaxilofacial da "BMF odontologia e cirurgia bucomaxilofacial Ltda." (Apêndice A) para obtenção da lista de pacientes submetidos à cirurgia ortognática e para validação do material educativo junto aos pacientes submetidos à cirurgia ortognática.

Aos pacientes que participaram da coleta de dados foi apresentado 0 termo de consentimento livre e esclarecido em duas vias (Apêndice $B$ para os pacientes do grupo focal e Apêndice $H$ para os pacientes que participaram da validação do material educativo). Aos juízes não foi necessário requerer termo de consentimento livre e esclarecido.

\subsection{PRIMEIRA FASE - REVISÃO DE LITERATURA}

Em uma primeira leitura livre sobre aspectos que envolvem a cirurgia ortognática, as possíveis complicações cirúrgicas deste procedimento chamaram atenção do pesquisador e o aprofundamento deste assunto foi escolhido para dar início a uma revisão integrativa da literatura.

\subsubsection{MATERIAL E MÉTODO}

A revisão integrativa da literatura é um dos métodos utilizados na prática baseada em evidências, que inclui análise de pesquisas relevantes para tomada de decisão e melhoria da prática assistencial ${ }^{98 .}$ Ela possibilita a síntese do estado do conhecimento de um determinado assunto por sua 
ampla abordagem metodológica referente às revisões, além de demonstrar lacunas que precisam ser preenchidas com a realização de novos estudos ${ }^{99}$.

A busca da literatura, realizada de maio até setembro de 2010, utilizou os portais da Biblioteca Virtual em Saúde (BVS) e PUBMED, que permitem acesso às revistas indexadas no EMBASE, SCOPUS, MEDLINE e LILACS, além do OVID e a base de dados do CINHAL com os descritores do Medical Subject Headings Section (MeSH) e Descritores em Saúde (DECS) utilizando a seguinte forma de busca: ((Intraoperative Complications) $O R$ (Postoperative Complications)) AND Orthognathic Surgical Procedures).

Foram incluídos somente estudos primários que respondessem à questão: "Quais as complicações cirúrgicas da cirurgia ortognática?", selecionados pelo título e resumo e, posteriormente, foram lidos integralmente os que atenderam ao critério de inclusão: discutir as complicações relacionadas à cirurgia ortognática.

Os critérios de exclusão foram estudos que discutem técnicas cirúrgicas, complicações não relacionadas diretamente à cirurgia ortognática, e estudos realizados em cadáveres ou animais. Aqueles repetidos em mais de uma base de dados foram analisados uma única vez. A figura 10 esquematiza o resultado da busca.

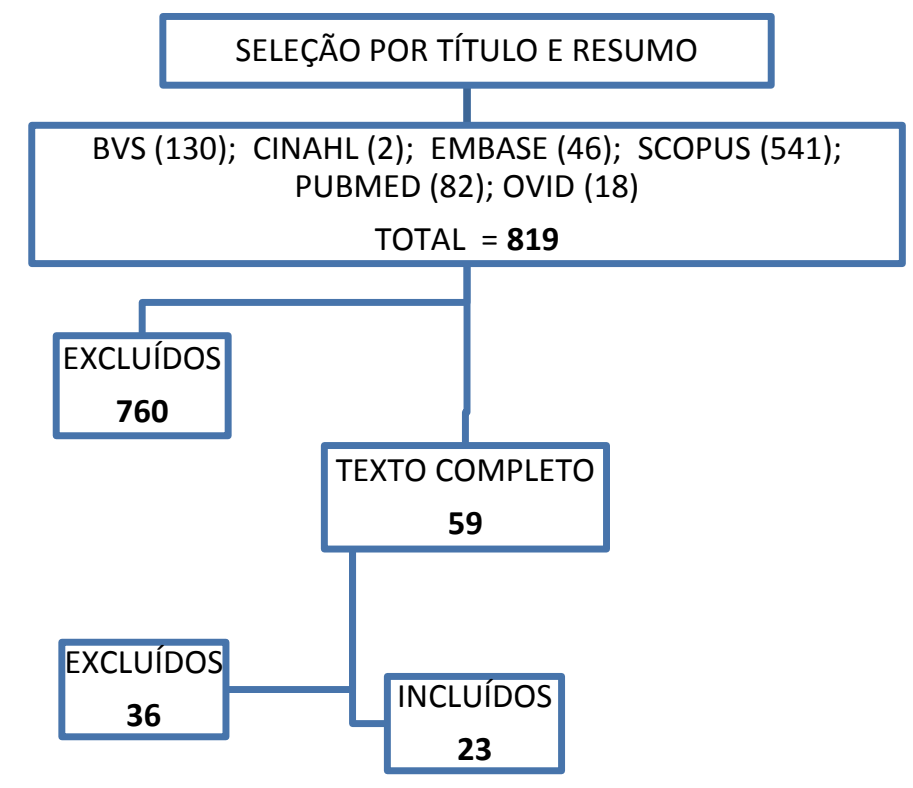

Figura 10 - Diagrama do processo de seleção dos artigos nas bases de dados. 


\subsubsection{RESULTADOS}

Foram analisados 23 artigos que atenderam aos critérios de inclusão, dos quais apenas um pertencia à década de 1980 e os demais à década de 2000. Os autores são da mesma área profissional (cirurgiões bucomaxilofaciais), e as revistas são da área de odontologia e cirurgia bucomaxilofacial, com destaque para o Journal of Oral and Maxillofacial Surgery pelo maior número de artigos encontrados.

As complicações comumente encontradas foram lesão de nervos, infecção, problemas com material de fixação, disfunção temporomandibular, fratura indevida, alteração na cicatrização e hemorragia (Tabela 5.1).

Tabela 5.1- Complicações distribuídas conforme população encontrada nos estudos - 2010

\begin{tabular}{|c|c|c|}
\hline \multirow[t]{2}{*}{ Complicação } & \multicolumn{2}{|c|}{ População } \\
\hline & $\mathbf{N}$ & $(\%)^{*}$ \\
\hline Lesão de nervos ${ }^{35-37,47-50,100-103}$ & 1018 & 12,13 \\
\hline Infecção $^{35,36,47,50,57,100,104}$ & 283 & 3,41 \\
\hline Material de fixação ${ }^{35,38,50,56-58}$ & 218 & 2,59 \\
\hline Disfunção temporomandibular ${ }^{35,59,105}$ & 177 & 2,10 \\
\hline Fratura indevida $^{35-37,50,59,100,106,107}$ & 152 & 1,81 \\
\hline Alteração na cicatrização ${ }^{40,100}$ & 150 & 1,78 \\
\hline Hemorragia $^{35-38,50,100}$ & 120 & 1,43 \\
\hline Osteotomia $^{34,37,38,50,58}$ & 53 & 0,63 \\
\hline Dor exacerbada ${ }^{35,37}$ & 27 & 0,32 \\
\hline Absorção condilar ${ }^{35}$ & 21 & 0,25 \\
\hline Laceração de tecido mole ${ }^{35,37,38}$ & 19 & 0,22 \\
\hline Mordida aberta ${ }^{37,56,58}$ & 16 & 0,19 \\
\hline Recidiva cirúrgica $^{35}$ & 16 & 0,19 \\
\hline Lesão dentária $^{34-37}$ & 16 & 0,19 \\
\hline Desvio septo nasal ${ }^{36,50}$ & 15 & 0,17 \\
\hline Má oclusão ${ }^{35}$ & 15 & 0,17 \\
\hline
\end{tabular}

*Porcentagem calculada sobre a população total dos estudos (8.390 pacientes). 
Embora os estudos encontrados não tenham abordado complicações relacionadas ao planejamento cirúrgico, aspectos envolvidos nesta etapa do procedimento podem comprometer qualquer momento do tratamento, seja por exame inadequado do paciente, erro no diagnóstico ou má interpretação dos dados clínicos ${ }^{108}$.

Outra complicação rara, porém importante, não citada nos resultados encontrados é a trombose do seio cavernoso, caracterizada pelo aumento da pressão dentro do seio cavernoso, impedindo a drenagem venosa da órbita e que pode levar à paralisia dos nervos cranianos VI, III, IV e hiperalgesia do nervo trigêmeo I e II. A perda da acuidade visual pode ocorrer devido à hipóxia da retina ${ }^{33}$. Um estudo de caso de trombose do seio cavernoso, supostamente causado por um quadro dentário infeccioso, foi publicado recentemente com achados clínicos primários de ptose e pupila fixa e dilatada ${ }^{109}$.

Dentre as complicações encontradas na literatura, para o material educativo foram selecionadas dor, ausência de união óssea ou quebra da placa, ausência de sensibilidade, hematoma, náuseas e vômitos e infecção. Consideradas as mais relevantes para o material educativo e também citadas pelos pacientes no momento de seu conhecimento.

\subsection{SEGUNDA FASE - CONHECIMENTO DOS INTERNAUTAS}

A interação em ambientes virtuais tem sido muito utilizada por pessoas de todas as idades. Por meio de comunidades virtuais, pessoas com afinidades ou que vivenciam uma mesma situação discutem cuidados ou trocam informações sobre a cirurgia.

\subsubsection{MATERIAL E MÉTODOS}

Tendo em vista a existência destas comunidades virtuais como oportunidade de conhecer as dificuldades vivenciadas pelos sujeitos da pesquisa, foi realizada uma busca na internet por comunidades virtuais e 
blogs (sites que utilizam interação por meio de posts), ou seja, comunidades virtuais e blogs onde o blogueiro (administrador) permite interação dos visitantes por meio de comentários sobre o tema do post e, assim, permite que indivíduos interajam e troquem experiências. Dentre as comunidades virtuais e blogs existentes optou-se por aquelas que não fossem administradas por cirurgiões ou clínicas de tratamento. Entre estes foram escolhidos por popularidade: Yahoo $\AA$; Orkut $\circledast$ e alguns blogs denominados com numeração para preservar o blogueiro: Blog 1; Blog 2; Blog 3; Blog 4; Blog 5 e Blog 6. A palavra chave aplicada nas redes virtuais para filtrar as comunidades foi "cirurgia ortognática" e o tempo de existência da comunidade não foi levado em consideração. O período de coleta compreendeu de Janeiro a Junho de 2011.

Devido à riqueza do conteúdo encontrado, optou-se por extrair todos os posts para arquivo Word $\Theta$, separados por endereço de blog, para posterior análise dos dados.

Análise dos dados: Optou-se pela técnica de análise de conteúdo para avaliação qualitativa do conteúdo dos blogs. Esse método compreende um conjunto de técnicas de pesquisa cujo objetivo é a busca do sentido ou dos sentidos de um documento. Tal momento reveste-se de suma importância, pois os dados são analisados levando-se em consideração os significados atribuídos pelo seu sujeito de pesquisa ${ }^{110}$.

A tentativa do analista é compreender o sentido da comunicação ao mesmo tempo em que desvia o olhar para outra significação e observa outra mensagem ao lado da mensagem primaria. A análise de conteúdo busca conhecer aquilo que está por trás das palavras sobre as quais se debruça ${ }^{111 .}$

Esse método consiste em três fases, sendo a primeira leitura flutuante de todo o texto para obter intuições, hipóteses, reflexões, um brainstorming individual; a segunda, da seleção de unidades de análise (recorte de trechos marcantes) para análise profunda do conteúdo. Esta corresponde a uma transformação dos dados brutos do texto que leva a representação do conteúdo, susceptível a esclarecer o analista à cerca das características do 
texto; e a terceira consiste em categorização (classificação de elementos encontrados e agrupamento dos semelhantes), pode ser aplicado conceito semântico, léxico, sintático ou expressivo, o objetivo é uma representação simplificada dos dados brutos ${ }^{110,111 .}$

\subsubsection{RESULTADOS}

\subsubsection{CARACTERIZAÇÃO DAS COMUNIDADES E BLOGS}

A busca na internet conforme proposto resultou em seis blogs e duas comunidades virtuais, totalizando oito sites com informações e discussões sobre a cirurgia ortognática, que resultaram em 1328 comentários de pacientes que estavam em fase pré e pós-operatória ou interessados no procedimento cirúrgico. Destes, 270 foram selecionados na primeira leitura de resultados. Após releitura, 204 comentários foram escolhidos e agrupados. Tabela 5.2 - Frequência de comentários encontrados e selecionados
segundo comunidades virtuais e blogs. São Paulo. 2011

Blog/Comunidade

Comentários

\begin{tabular}{lcc} 
& Encontrados & Selecionados \\
Blog 1 & 230 & 40 \\
Blog 2 & 03 & 03 \\
Blog 3 & 80 & 32 \\
Blog 4 & 29 & 07 \\
Blog 5 & 471 & 86 \\
Blog 6 & 28 & 10 \\
Yahoo & 141 & 46 \\
Orkut & 346 & 46 \\
\hline Total & $\mathbf{1 3 2 8}$ & $\mathbf{2 7 0}$ \\
\hline
\end{tabular}


Os blogs apresentaram característica semelhante à de um diário: os pacientes dispõem de informações sobre seu processo perioperatório, alguns utilizam fotos da evolução de pós-operatório, outros contam dia após dia, há comentários daqueles que visitam o site e, assim, pacientes ou curiosos questionam, discutem informações, trocam experiências e condutas médicas.

Nas comunidades virtuais, os comentários e discussões estão presentes, tópicos de discussões são colocados pelo proprietário da comunidade e cada um expressa sua opinião, vivência e questionamentos.

Acredita-se que na internet o paciente tenha mais liberdade para se expressar, uma vez que não necessita expor-se perante o outro para dizer 0 que deseja, mas isso não o leva a manter-se no anonimato na rede social, pois a quantidade de comentários definidos como anônimo representa apenas $4 \%$ dos comentários encontrados.

Se os nomes dados são reais é uma questão que fica pendente, pois como não se possui contato com estas pessoas não se pode garantir que $o$ nome utilizado seja o nome real.

A internet pode ser benéfica para a agilidade da informação, mas quando expõe informações errôneas pode ser prejudicial para o individuo leigo, que por falta de conhecimento não difere o certo do errado e pode causar complicações cirúrgicas.

Um estudo realizado em Seatlle ${ }^{112}$ refere as cinco razões mais comuns pelos quais o paciente utiliza a internet para pesquisa relacionada a saúde: 1. Informações sobre uma condição, 2. Informações sobre o tratamento, 3. Informações sobre sintomas, 4. Conselhos sobre os sintomas, e 5. Conselhos sobre o tratamento.

Os pacientes podem tomar decisões potencialmente inadequadas sobre como prosseguir com o tratamento da cirurgia ortognática, que por natureza, é um tratamento prolongado ${ }^{113 .}$ 
Em um dos blogs encontrados a administradora do blog dá dicas de cuidados pós-operatórios, faz orientações sobre o processo perioperatório e repassa sua experiência como paciente aos demais, inclusive com condutas de tratamento.

Outro blog de origem portuguesa recebeu muitos posts de brasileiros, e possibilitou a interação entre portugueses e brasileiros, além de apresentar comentários e dúvidas sobre o processo cirúrgico semelhantes em ambos os países.

Um estudo do Reino Unido com objetivo de avaliar a qualidade da informação colocada na internet sobre a cirurgia ortognática constatou que, apesar de encontrar no Google quase um milhão de links para sites, apenas 25 websites dos 100 maiores encontrados continham informações relevantes para os pacientes. Destes, apenas seis forneciam informação médica de qualidade, a um nível que poderia ser o recomendado para pacientes submetidos a cirurgia ortognática ${ }^{113 .}$

\subsubsection{ANÁLISE DE CONTEÚDO}

Os dados analisados pelo método de análise de conteúdo tinham como objetivo retratar quais as informações, orientações e cuidados estavam presentes na internet e como o paciente faz uso desta ferramenta para os cuidados pós-operatórios com intuito de acrescentar informações na construção do material educativo.

Após a leitura de todos os comentários, uma seleção foi realizada e aqueles, por sua vez, foram agrupados pelo pesquisador por semelhança em categorias para facilitar a organização na análise de conteúdo, sendo estas: dúvidas levantadas no período perioperatório, medos enfrentados durante o período perioperatório, recuperação pós-operatória, alteração da estética facial e arrependimento do procedimento cirúrgico. 


\section{Dúvidas levantadas no período perioperatório}

As dúvidas encontradas abrangem questões sobre dor, alimentação, parestesia, higiene oral, alteração da sensibilidade, alteração da voz, anestesia, edema, sangramentos, retorno às atividades rotineiras, quando volta a beijar, como é o procedimento cirúrgico.

Nota-se boa parte dos pacientes comparando evoluções de pósoperatório, sem se dar conta de que cada um de nós possui um tempo para a recuperação, e que pode haver diferenças no pós-operatório de um paciente para outro.

"queria saber quanto tempo mais ou menos vc fica com a boca dormente, queria saber quando volta a sensitividade total na boca, quanto tempo leva para o inchaço desaparecer completamente, se sai muitas espinhas e se elas prejudicam muito a sua pele" [blog 3]

Atualmente é comum o paciente buscar respostas na internet, e começar a se familiarizar com os tratamentos oferecidos a sua patologia. Isso permite conhecer a dimensão do tratamento, vivenciar as experiências alheias e oferece a oportunidade para fazer perguntas de uma forma mais livre, sem receios.

Em um dos comentários o paciente curioso demonstra desconhecimento sobre o procedimento cirúrgico e busca resposta na internet.

"Será que a cirurgia é dolorida com a retirada do siso?"[Yahoo]

Nota-se que ele não possui nenhum conhecimento sobre o assunto. Talvez seja seu primeiro questionamento sobre a cirurgia e a resposta adquirida pode interferir na sua decisão de busca pelo tratamento.

A alimentação, apesar de importante para a recuperação, não foi um questionamento frequente nestes sites; os poucos comentários encontrados resumem-se à consistência dos alimentos. 
Por outro lado, o questionamento sobre relacionamentos foi frequente, diferentemente do que se vê no consultório. $\mathrm{Na}$ internet o paciente parece se sentir livre para perguntas que considera mais íntimas.

(...) "queria saber o seguinte: Para beijar na boca, abrir a boca, mexer, sentir, tuudo normal.., depois de 1 ano?"[blog 5]

“Em quanto tempo dá para beijar na boca de verdade?"[Orkut]

"Com quantos dias vc deu seu primeiro beijo depois da cirurgia?"[blog 5]

"Quanto tempo depois de feita a cirurgia consegue beijar?" [blog 2]

Nota-se na primeira frase, a escrita da palavra tudo com repetição de vogais na sílaba tônica, como se simbolizasse a intensidade do fenômeno. Esta situação também se verifica em frases com outros conteúdos.

A parestesia e sensibilidade da área operada foram pontos discutidos com maior frequência. O paciente apresenta ansiedade na reversão da parestesia e tenta compreender a diminuição da sensibilidade enquanto partilha seus sentidos com os demais.

"A parestesia me incomoda mtooo (...)Vc jah esta no setimo mês, a sua parestesia melhorou comparando com o terceiro mês??" [blog 3]

"Queria saber quanto tempo mais ou menos vc fica com a boca dormente, queria saber quando volta a sensitividade total na boca"[blog 3]

“... alguem ficou com sem sentir o céu da boca ...quanto tempo para vooltar?"[Orkut]

"Gente, quanto tempo demora pro rosto voltar a ter expressões??"[Orkut]

O profissional orienta durante o pré-operatório sobre o tempo requerido para retorno da sensibilidade e a possibilidade de reversão parcial da parestesia após a cirurgia. Entretanto, quando o paciente vivencia a experiência da perda da sensibilidade e a dificuldade que esta acarreta para realizar expressões faciais e contenção da saliva na cavidade oral, os anseios pela cura imediata podem fazer com que ele acredite que há algo de errado e o leve a compartilhar sua experiência em busca de reconhecer-se no próximo. 
O período de retorno das atividades de rotina e os cuidados empregados com a higiene oral durante o pós-operatório são questões levantadas pelos internautas.

"Gostaria de saber de quem já fez a cirurgia, quanto tempo depois da cirurgia vocês voltaram a trabalhar, a estudar?"[Orkut]

“Vc. teve alguma dificuldade com a limpeza?"[blog 3]

"Minha língua ta com uma capa esbranquiçada e que as vezes incomoda bastante parece ate que queimei a língua. Alguem teve isso? É normal? Como tratou?"[Orkut]

Estas informações são passadas pelo profissional, mas na inabilidade do paciente de lembrar-se da informação recebida e possível vergonha de dizer isso ao seu cirurgião ou na impossibilidade de encontrá-lo de forma imediata, a internet torna-se a fonte para uma resposta rápida ao paciente. Algumas informações encontradas na internet podem ser prejudiciais, se outro internauta o orienta a realizar a higiene oral de forma equivocada, por exemplo.

Por outro lado, apesar de orientado de forma correta, o paciente esquece a informação recebida e pode realizar a atividade sem o cuidado que lhe é devido.

\section{Medos enfrentados durante o período perioperatório}

Os medos estão relacionados à anestesia, aos riscos cirúrgicos, ao processo de recuperação, ao procedimento cirúrgico e ao resultado estético. O medo em qualquer fase do perioperatório é muito comum em qualquer tipo de cirurgia.

\section{“A anestesia na cirurgia ortognática pode matar?”[Yahoo] "estou com medo da recuperação, mas um medo enorme da anestesia geral"[blog 3]}

A interação nessas comunidades virtuais permite a melhor visão de imagens sobre a técnica cirúrgica. Até mesmo pessoas que já passaram por este processo tiram fotos de cada período vivenciado e as colocam na internet em seus blogs para compartilhar com outras pessoas suas 
experiências. Vídeos gravados durante 0 intraoperatório podem ser encontrados em sites demonstrando como é a realizada a cirurgia.

\author{
"(...)to me controlando pra não entrar em desespero com o \\ p.o."[blog 4] \\ "Confesso que o medo esta tomando conta"[blog 4] \\ "Mas quando comecei a ver as fotos me deu até frio na barriga e \\ uma sensação de desespero...rs."[blog 5] \\ “Com medo que o resultado nao seja o esperado tipo será q posso \\ ficar pior" [blog 3]
}

Para alguns pacientes este tipo de informação supre a curiosidade e dá conhecimento para vivenciarem seu próprio período perioperatório. Entretanto, para outros, o processo cirúrgico é agressivo e assusta o paciente, e eles desistem da cirurgia por medo de vivenciar aquilo que visualizaram na internet.

\title{
Recuperação pós-operatória
}

Alguns pacientes buscam entender o pós-operatório e criam expectativas sobre aquilo que vão vivenciar, outros expõem alguma dificuldade vivenciada.

"Gostaria de saber como é a recuperação de uma cirurgia ortognática?"[Yahoo]

"A cirurgia ortognatica deve ser muito traumática?"[Yahoo]

"Mas os primeiros dias foram muito sofridos e tive muita falta de ar, insônia e uns calorões (que pareciam ser devido à alguma medicação)" [blog 3]

Aqueles que vivenciaram o processo e colocam os pontos positivos do processo de recuperação proporcionam motivação para outros pacientes e criam vínculo com outras pessoas.

“(...) ler suas dicas foram muito importantes, principalmente há dos três meses, que não dá para esperar muitos resultados antes disso". [blog 3]

"Olha o pós-cirurgico não é doloroso, mas é muuuito incômodo."[blog 5]

Estar ciente do processo de recuperação é importante para o paciente, porque pode diminuir a ansiedade para obter o resultado cirúrgico 
final, facilita o pós-operatório e faz com que complicações possam ser evitadas.

Entretanto, este mesmo paciente que está ciente dos cuidados exigidos na recuperação pode vir a buscar na internet solução para um sintoma que faz parte da recuperação, como, por exemplo, o edema facial, e encontrar soluções que não são indicadas e podem ser prejudiciais.

"Fico o dia todo na internet, vendo qual a melhor maneira de fazer, se coloco gelo, se coloco compressa de água morna, qual são as massagens ideais a serem feitas, etc"[blog 5]

A internet é a nova fonte de busca de informações, mas pode ser uma vilã para questões de saúde, pois não se pode garantir que toda a informação colocada esteja baseada na ciência.

Com isso, o profissional deve estar atento a tomar para si as orientações e suprir a necessidade do paciente.

\section{Alteração da estética facial}

A cirurgia proporciona uma alteração do perfil facial, e alguns pacientes não estão preparados o suficiente para enfrentar esta mudança ou não imaginam o quão significativa essa alteração pode ser.

"Uma das coisas q eu mais fico pensando é se as pessoas ainda vão me reconhecer depois da cirurgia, você mudou muito???" [blog 4]

"Sabe que eu demorei a me reconhecer no espelho. A imagem que tinha de mim mesma não era a que via no espelho" [blog 5]

"Durante muito tempo só me vinha a mente minha imagem antes da cirurgia e por isso toda vez que eu me olhava no espelho achava estranho, como se não fosse eu e durante um tempo me achava melhor antes da cirurgia." [blog 5]

É necessário um tempo para que a pessoa se acostume com as modificações em sua face. O perfil facial com que ela viveu até o momento é alterado de forma repentina, logo, é natural que o cérebro leve um tempo para processar o reconhecimento da nova face. 
Com isso, é importante que o paciente seja orientado quanto a esta possível alteração de comportamento no pós-operatório e quanto ao fato de que cada paciente terá o seu tempo de adaptação e aceitação do novo perfil.

\section{Arrependimento do procedimento cirúrgico}

O arrependimento pode ocorrer com o paciente que criou expectativas diferentes das condições reais de pós-operatório ou com aquele que não compreende o período longo de recuperação ou ainda aquele que não aceita a mudança recente.

Alguns pacientes referiram-se ao edema facial como um fator que contribuiu para o arrependimento, porque ainda não visualizam o resultado final e o perfil facial intermediário muitas vezes era menos estético que o anterior.

(...) "Uns dias atrás tive umas crises novamente, chorei, fiquei nervosa, senti saudades do meu rosto antigo, principalmente depois de ver minhas fotos recentes e constatar que não sei mais sorrir e meu rosto ainda parece um smile de tão redondo!"[blog 5]

"Tem dias que eu simplesmente me arrependo de ter feito a cirurgia. Porque o rosto demora demais para ficar $100 \%$ bom, daí eu fico aflita pensando que talvez teria sido melhor não ter feito..."[blog 5]

"Continuo rezando mto $p$ melhorar cada dia mais e espero $q$ esse arrependimento q eu tenho, um dia saia da minha cabeça”. [blog 5]

"Sabe oq acontece, eh q meu problema não era tao aparente, então hj em dia eu vejo minhas ftos de antes e penso q eu to passando por tudo isso e não estou feliz, nem satisfeita" [blog 5]

A pouca orientação fornecida ao paciente pelo profissional e a dificuldade do paciente durante o pós-operatório foram colocados como fatores de arrependimento que podem estar relacionados a falhas na comunicação profissional-paciente.

"Juro ngm mais $m$ aguenta d tanto q eu choro e me arrependo da cirurgia sabe? Acho q os médicos deviam explicar melhor sobre essa cirurgia, pq $n$ eh fácil e $p$ eles dps $d 4$ meses, agnt jah está recuperada. Soh q nao eh bem assim pq isso q agnt sente é um sintoma, q soh agnt sente, não é algo q ele vê". [blog 5]

"Eu choro $m t$ td dia, vou ver ate $c$ vou em outro medico $p$ tirar dúvidas pq para o meu medico parece $q$ eu foi apenas mais uma paciente sab?"[blog 5] 
Alterações faciais afetam diretamente a autoestima do ser humano. Quando os pacientes se sentem realizados com o resultado cirúrgico, melhoram sua autoestima e, consequentemente o modo como se relacionam com os demais, obtendo melhor qualidade de vida.

Quando o resultado não é o esperado, ou demora para ser alcançado, o paciente pensa em voltar atrás neste processo, que não tem volta pois uma vez a cirurgia realizada não há como desfazê-la. O arrependimento é criado e, dependendo do caso, o paciente necessitará de ajuda psicológica para lidar com esse arrependimento.

A internet possibilitou uma visão ampla dessa população. Nota-se que, por meio da interação de vários países, estados e cidades, pessoas desconhecidas trocam informações sobre seus problemas de saúde em sites públicos, ao qual qualquer um pode ter acesso e compartilhar.

\subsection{TERCEIRA FASE - PERCEPÇÃO DOS PACIENTES SOBRE O PÓS-OPERATÓRIO DE CIRURGIA ORTOGNÁTICA}

Julgou-se importante considerar as necessidades de informação do paciente a partir de sua percepção sobre o pós-operatório de cirurgia ortognática. O educador precisa fazer esta aproximação com o paciente para que o material educativo possa realmente conter informações importantes ao paciente e estar direcionado para atender suas necessidades.

\subsubsection{MATERIAL E MÉTODO}

A técnica de pesquisa qualitativa adotada foi a denominada "grupo focal”, que permite a obtenção das informações de interesse por meio da reunião de indivíduos em uma sessão que pode ser definida como uma entrevista coletiva, na qual um pequeno número de participantes (não mais que 12), sob a coordenação de um pesquisador/moderador, conversam sobre tópicos relevantes para a investigação em questão (quais as dúvidas 
desta população referente a cirurgia?), num período de tempo não superior a $2 \mathrm{~h}$ de duração ${ }^{114}$.

Os participantes apresentam características e práticas comuns bem como características diversas, tais como idade, escolaridade, nível socioeconômico, entre outras ${ }^{115}$.

A discussão é a base pela qual a informação é obtida. A interação entre os participantes do grupo é encorajada, estimulando assim as discussões em profundidade sobre os tópicos de interesse do estudo. Para assegurar que os tópicos ou temas de interesse sejam discutidos pelo grupo, o pesquisador/moderador introduz os temas para a conversação e apoia a participação dos indivíduos para que contribuam com suas ideias ${ }^{116 .}$

A discussão do grupo pode ser gravada para posterior transcrição dos dados, evitando perdas do conteúdo discutido. Anotações sobre o comportamento podem ser realizadas por um observador, que auxilia 0 pesquisador/moderador. Essa troca possibilita elucidar e compreender a manifestação de determinadas atitudes, por meio da análise das motivações que os influenciam. Trata-se de uma abordagem não indutiva, na qual se estimulam a expressão espontânea e a reflexão acerca de sentimentos, valores e atitudes ${ }^{116 .}$

Para este estudo foram formados dois grupos: pacientes em fase préoperatória e pacientes em fase pós-operatória de cirurgia ortognática. Os pacientes foram recrutados do consultório de cirurgia e traumatologia bucomaxilofacial da "BMF Odontologia e Cirurgia Bucomaxilofacial Ltda.".

No grupo pós-operatório, os pacientes operados nos dois últimos anos foram selecionados aleatoriamente do arquivo do consultório e por contato telefônico foram convidados a participar da pesquisa; aos que aceitaram participar, foi informada a data, hora e endereço do encontro do grupo.

No grupo pré-operatório, os pacientes em fase de planejamento cirúrgico, de finalização da ortodontia pré-operatória e aqueles com cirurgia 
marcada para data posterior à do encontro foram convidados por telefone para participar da pesquisa; aqueles que aceitaram foram informados do endereço, data e hora do encontro do grupo.

Um roteiro de questões foi criado para que o pesquisador/moderador tivesse à mão um guia para conduzir o grupo e atingir o objetivo de conhecer a população e obter suas dúvidas relacionadas ao procedimento cirúrgico.

1) Roteiro para o grupo focal I - pacientes em pós operatório

Para condução do grupo focal I, um roteiro com algumas questões abertas (quadro 5.1), produzidas anteriormente à data do encontro do grupo, foi adotado para auxiliar a pesquisadora. As questões foram sendo colocadas pela pesquisadora conforme decorria a discussão.

Quadro 5.1 - Roteiro produzido para condução do grupo focal I

Como vocês veem a utilização de um material educativo que facilite os cuidados pós-operatórios?

Vocês encontraram alguma dificuldade em relação às orientações fornecidas sobre os cuidados pós-operatórios?

Quais os assuntos vocês consideram importantes para serem trabalhados no material educativo?

Você está satisfeito com o resultado da cirurgia?

Qual o melhor momento para entrega do material educativo?

Existe alguma coisa que não tenha sido exposta e sobre a qual você gostaria de conversar ou teria algo a sugerir?

2) Roteiro para o grupo focal II - pacientes em pré-operatório

Para condução do grupo focal II outro roteiro foi desenvolvido para atender especificamente este perfil de pacientes (quadro 5.2). As questões foram sendo colocadas pela pesquisadora conforme decorria a discussão. 
Quadro 5.2 - Roteiro produzido para condução do grupo focal II

Como vocês veem a utilização de um material educativo que facilite os cuidados pós-operatórios?

Que tipo de dúvidas vocês possuem sobre a cirurgia? Como vocês imaginam que será depois da cirurgia? E o que esperam do pós-operatório?

Quais os assuntos que vocês consideram importantes para serem trabalhados no material educativo?

Qual o melhor momento para entrega do material educativo?

Existe algum assunto que não tenha sido exposto e sobre a qual você gostaria de conversar ou teria algo a sugerir?

Neste estudo, ambas as reuniões com o grupo focal foram realizadas em uma sala do consultório de uma equipe de cirurgiões bucomaxilofaciais, localizado no bairro da Bela Vista, na cidade de São Paulo, com facilidade de acesso por transporte público e em uma data em que não havia atendimento médico, para que se pudesse proporcionar mais tranquilidade e liberdade ao grupo. O local escolhido está em conformidade com a descrição dos estudos ${ }^{114,115}$ que descrevem o local para o encontro do grupo focal como um ambiente confortável, que assegure privacidade e seja de fácil acesso aos participantes.

A sala foi organizada de modo que as cadeiras ficassem dispostas em semicírculo, permitindo aos participantes a melhor visão e interação entre todos; som ambiente com músicas da natureza foi disposto para criar ambiente relaxante.

A pesquisadora participou do grupo como moderadora e duas outras pessoas participaram como observadoras, sendo uma delas a orientadora desta pesquisa e a outra aluna da graduação de enfermagem. O papel das observadoras era registrar os dados e informações verbais e não-verbais apresentadas pelos participantes.

No dia do encontro com o grupo, a pesquisadora agradeceu o comparecimento dos participantes, apresentou os integrantes desta pesquisa (pesquisador e observadores), explicou os objetivos da pesquisa e como seria conduzido o grupo, bem como a necessidade de gravação da 
discussão. Foi assegurado o anonimato e confidencialidade dos dados obtidos. O termo de consentimento livre e esclarecido foi apresentado e aqueles que aceitaram participar assinaram o termo em duas vias.

Ao término do grupo focal, um coffee-brake foi oferecido aos participantes e entregue um brinde de chocolate e kit higiene oral como agradecimento pelo comparecimento e participação.

Ao final de cada grupo, uma avaliação do grupo foi realizada pelo pesquisador/moderador e observadores, com análise dos itens "organização e tranquilidade do ambiente", "tempo adequado", "roteiro aplicado", "interação, entusiasmo, programação do grupo", "resumiu as ideias principais", conforme quadro 5.3 .

Quadro 5.3 - Roteiro para avaliação do desempenho do grupo I e II

\begin{tabular}{|l|l|l|l|}
\hline & Sim & Não & Comentário \\
\hline A organização do lugar foi boa? & & & \\
\hline O ambiente estava tranquilo, sem interrupções? & & & \\
\hline O tempo foi adequado? & & & \\
\hline O guia temático foi completo, cumpriu sua função? & & & \\
\hline Estimulou a integração do grupo? & & & \\
\hline Promoveu o entusiasmo e a participação? & & & \\
\hline Respeitou a programação? & & \\
\hline Resumiu as ideias principais? & & \\
\hline
\end{tabular}

Análise dos dados: A análise dos dados da avaliação do grupo focal é proposta como um conjunto de procedimentos que visam a organizar os dados de modo que eles revelem, com a máxima objetividade e isenção possível, as informações obtidas, sendo indicado o método de sumário etnográfico e ou a codificação de dados via análise de conteúdo ${ }^{114 .}$

Neste estudo, optou-se por realizar o método de análise de conteúdo, a mesma técnica descrita para análise dos dados do conteúdo da internet, na segunda fase desta trajetória metodológica. 


\subsubsection{GRUPO FOCAL I - PACIENTES EM PÓS-OPERATÓRIO}

Para o grupo de pós-operatório foram convidados 33 pacientes por contato telefônico, com dez dias de antecedência da data marcada para o encontro do grupo; 15 deles negaram a participação por impossibilidade de comparecimento na data e distância do trajeto da residência ao local do grupo; dois não atenderam ao telefone; em dois, o número de telefone informado não existia; cinco estavam com o telefone fora de área ou impossibilitado de receber chamada; nove pacientes confirmaram presença.

$\mathrm{Na}$ data e hora marcada compareceram cinco pacientes, demonstrando absenteísmo de $44 \%$. As variáveis: idade, sexo e tempo de cirurgia são apresentados no quadro 5.4 .

Quadro 5.4 - Identificação dos pacientes do grupo focal de pós-operatório segundo sexo, idade e tempo de cirurgia. São Paulo, 2011

\begin{tabular}{|c|c|c|c|}
\hline $\mathbf{N}$ & Idade & Sexo & $\begin{array}{c}\text { Tempo de cirurgia } \\
\text { (em meses) }\end{array}$ \\
\hline 1 & 46 & $\mathrm{~F}$ & 21 \\
\hline 2 & 34 & $\mathrm{~F}$ & 8 \\
\hline 3 & 49 & $\mathrm{M}$ & 6 \\
\hline 4 & 43 & $\mathrm{M}$ & 6 \\
\hline 5 & 27 & $\mathrm{M}$ & 5 \\
\hline
\end{tabular}

Observa-se um número maior de participantes do sexo masculino neste grupo, o que não permite dizer que a cirurgia é realizada mais em pacientes do sexo masculino, pois, analisando o gênero dos 33 pacientes convidados, teríamos predominância do sexo feminino (66,6\%).

A idade média deste grupo é de 39,8 anos. Não se obteve a idade de todos os pacientes convidados, impedindo a comparação com o dado do grupo. 


\subsubsection{GRUPO FOCAL II - PACIENTES EM PRÉ-OPERATÓRIO}

Para o grupo de pré-operatório foram convidados dez pacientes por contato telefônico com dez dias de antecedência da data marcada para o encontro do grupo; dois deles negaram participação por impossibilidade de comparecimento na data proposta; um ficou de confirmar disponibilidade e, em outra data, o telefone não atendia mais as ligações; sete confirmaram presença.

Este número pequeno de pacientes convidados a participar da pesquisa se deve pela fase em que os pacientes se encontraram, pois até a data marcada para o grupo alguns pacientes foram submetidos a cirurgia não atendendo mais ao critério usado para este grupo. Outros pacientes estavam em fase muito inicial do tratamento ortognático com previsão de cirurgia para 18 a 24 meses, não caracterizando um paciente em preparo cirúrgico.

$\mathrm{Na}$ data e hora marcada compareceram três pacientes, demonstrando absenteísmo de 57\%. Apesar do número de participantes abaixo do recomendado para um bom aproveitamento do grupo, optou-se por dar continuidade ao encontro em respeito aos que compareceram ao local marcado.

As variáveis idade, sexo e tempo previsto para cirurgia são apresentadas no quadro 5.5 .

Quadro 5.5 - Identificação dos pacientes do grupo focal de pré-operatório segundo sexo, idade e tempo previsto para a cirurgia. São Paulo, 2011

\begin{tabular}{|c|c|c|c|}
\hline $\mathbf{N}$ & Idade & Sexo & $\begin{array}{c}\text { Tempo para a } \\
\text { cirurgia (em dias) }\end{array}$ \\
\hline 1 & 25 & F & 180 \\
\hline 2 & 28 & F & 13 \\
\hline 3 & 23 & M & 5 \\
\hline
\end{tabular}


Em relação às variáveis apresentadas, observa-se predominância do sexo feminino neste grupo, com idade média de 25,3 anos. O tempo de préoperatório fez diferença significativa no desenvolvimento do grupo. Pacientes com data mais próxima da cirurgia estavam mais esclarecidos sobre a cirurgia em relação a pacientes com data cirúrgica mais distante.

\subsubsection{IMPRESSÔES SOBRE O GRUPO FOCAL}

O grupo focal I foi participativo na discussão, houve interação entre os participantes e o pesquisador e teve duração de 60 minutos. Apesar de ser um grupo com número mínimo recomendado, as informações passadas pelos participantes do grupo foram repetitivas e atingiram a necessidade do pesquisador de conhecer a população, não requerendo outros encontros, nem mesmo outros grupos de pós-operatório. No grupo I todos os itens da avaliação foram positivos, confirmando o bom desempenho na realização deste encontro. Uma avaliação com pontos negativos permitiria ao pesquisador rever estes pontos para uma próxima intervenção, trazendo melhorias no processo do grupo focal.

O grupo focal II foi introspectivo, trazendo pouca informação para discussão. Isso pode ser justificado pelo número menor de participantes do que o recomendado; pela fase do tratamento em que se encontra o paciente, ou seja, diferença de tempo para cirurgia entre os participantes, fazendo com que o paciente mais próximo da cirurgia estivesse mais esclarecido sobre o pós-operatório e o paciente mais distante menos informado; pelo fato de que estes pacientes ainda não vivenciaram a fase pós-operatória e por este motivo não apresentam dúvidas sobre o período não vivenciado; pela característica pessoal que alguns pacientes possuíam de não querer saber detalhes sobre a cirurgia e estar focado apenas no resultado desejado; pela ansiedade que vivencia com a proximidade da cirurgia impedindo de participar efetivamente do grupo.

Apesar de esforços do pesquisador o grupo não se desenvolveu e manteve-se inibido, limitando-se a ouvir e não opinar, mesmo com o 
estímulo do pesquisador. A aplicação do roteiro proposto e o desempenho do grupo garantiu uma duração de apenas 45 minutos de interação.

Após a saída dos participantes, uma avaliação do desempenho do grupo foi realizada pela pesquisadora e as observadoras. Nesta avaliação dois itens da avaliação de desempenho não foram atendidos positivamente: os itens referentes ao entusiasmo e integração do grupo, demonstrando $75 \%$ de assertividade neste grupo. Esse resultado está ligado à inibição e à pouca participação do grupo de pré-operatório.

Com isso, define-se que um grupo de pacientes pré-operatório não acrescenta informação para esta pesquisa, pois dificilmente conseguir-se-ia reunir pacientes no mesmo momento cirúrgico, ou seja, com datas cirúrgicas muito próximas para ter o mesmo nível de informação sobre a cirurgia e discutir as dúvidas, ou até mesmo garantir que estes pacientes pudessem estar interessados em particularidades do pós-operatório não vivenciado.

Desta forma a análise de conteúdo apresentada relaciona-se apenas ao grupo focal I dos pacientes no pós-operatório.

\subsubsection{ANÁLISE DE CONTEÚDO}

A análise dos dados, realizada pelo método de análise de conteúdo, tinha como objetivo retratar quais as informações, orientações e cuidados necessários aos pacientes submetidos à cirurgia ortognática deveriam constar em um material educativo.

Os comentários dos pacientes foram identificados como $R$ de resposta e o número do respondente, permitindo o sigilo do paciente, conforme o termo de consentimento livre e esclarecido.

A análise de conteúdo permitiu que o conteúdo gravado fosse dividido e classificado em categorias criadas pelo pesquisador para agrupamento dos itens que se assemelham. Sendo assim, foram determinadas as categorias: assuntos a serem abordados no material educativo; dificuldades vivenciadas pelos pacientes; tempo de recuperação da cirurgia e 
autoimagem; resultados estéticos do procedimento cirúrgico; importância do material educativo e momento da entrega do material educativo.

\section{Assuntos a serem abordados no material educativo}

Ao indagar dos pacientes sobre o assunto a ser abordado no material educativo, foram apontados como pontos importantes os seguintes itens: alimentação, pontos de sutura, higiene oral, repouso, edema, processo da recuperação durante o pós-operatório e como seria a melhor visão da cirurgia no exame de imagem no pós-operatório.

“(...) Ela (a médica) só falou pra mim que eu tinha que comer coisa... é... líquida, pastosa, fria. (relatando a necessidade de especificar o que pode ou não pode comer)" [R3]

A dificuldade dos pacientes não está na consistência da dieta, mas nos alimentos que podem ser ingeridos durante a dieta. Uma dieta equilibrada é essencial para uma boa recuperação. Durante o período de dieta líquida muitos pacientes abrem mão de alimentos nutritivos que podem ser batidos e coados para tornarem-se líquidos, preferindo ingerir milkshakes, sucos, refrigerantes e sopas em pó.

Ao vivenciar o período de pós-operatório, os pacientes descobriram que a cirurgia exige mais do que outros procedimentos cirúrgicos mais simples, nos quais logo após a cirurgia retorna-se à rotina diária. Este foi um ponto importante colocado pelo grupo, para que os demais pacientes compreendam que há necessidade de um "processo" para a total recuperação.

\footnotetext{
"Acho que uma outra coisa que tem que ficar no manual (...) uma coisa que deve ficar clara é que é uma cirurgia, que ela é um processo de recuperação".[R4]
}

A curiosidade ou a falta de conhecimento levaram os pacientes a questionarem como seriam as placas e parafusos que o cirurgião informa colocar durante a cirurgia e como isso fica na estrutura óssea da face.

(...) "Pela panorâmica, eu consegui ver realmente o que eu tinha feito. (...) as plaquinhas, aonde aumentou, onde reduziu. (...) Então, de repente, até isso, né, na hora de dar as orientações, 
dela (a médica) mostrar alguma coisa e falar "olha, aqui a gente vai fazer isso, vai ficar desse jeito...".[R3]

Uma das pacientes chegou a comentar que o médico do trabalho gostaria de saber como era esta cirurgia que tinha sido realizada e que ela não sabia informar. Logo, visualizar no material educativo como é este material pode esclarecer não só o paciente quanto ao procedimento, mas também outras pessoas que direta ou indiretamente participam do contexto do pós-operatório.

(...) "eu chegava lá no servidor pra trocar o atestado e eles falavam "mas o que fez?", e eu tentava explicar e eles também não compreendiam porque o clínico geral, ele não tem... não tem noção do que que é, né?"[R2]

Com relação ao edema facial, o tempo de redução do edema e as terapias para auxiliar a reduzi-lo, alguns pacientes trouxeram à tona o questionamento sobre a drenagem linfática, apesar de não indicada por muitos profissionais devido à manipulação da região cirúrgica.

(...) "Seria interessante colocar a questão da massagem, de como a pessoa fazer a massagem e o tempo... e alertar, né, que aquilo leva um tempo, um tempo considerável! Porque você acha que em um mês aquilo vai diminuir e passa um mês, passa dois e aquilo não diminui".[R3]

\section{Dificuldades vivenciadas pelos pacientes durante o pós-operatório}

Algumas dificuldades foram colocadas pelo grupo durante vivência do período pós-operatório, e se destacaram questões de higiene oral, alimentação, troca da borracha do aparelho ortodôntico, exercícios faciais e relacionamento com outras pessoas que não vivenciaram este processo cirúrgico.

A higiene oral foi discutida quanto à dificuldade, tipo de escova e como realizá-la. Mesmo após a orientação do profissional, alguns pacientes não conseguiram realizar a higiene, o que torna preocupante o pósoperatório, pois é um dos cuidados fundamentais para uma boa recuperação e prevenção da infecção.

(...) "A dificuldade foi de executar algumas coisas: a escovação, porque se tá muito inchaço, eu tenho que ficar levantando, né, a bochecha pra passar a escova. Então eu tinha muita dificuldade 
com isso, né, levei mais de uma semana pra conseguir tirar todo o sangue porque eu não conseguia escovar direito" [R4]

(...) "Ela (a médica) fala que tem que limpar, mas você não consegue alcançar e tem que, né... fazer, tipo, um bochecho e você não consegue fazer.... (...) É difícil mesmo essa questão da higiene! Eu não sei se é questão da dor ou se é questão (...) de má orientação, mas, assim, eu tive dificuldade, bastante!" [R3]

(...)" As orientações foram muito claras. A dificuldade era de seguir algumas orientações, por exemplo, eu... ela (a médica) passou um enxaguante bucal e eu não conseguia fazer o "bocejo", não dava pra fazer o "bocejo", eu mal conseguia escovar os dentes porque eu não conseguia cuspir, eu não tinha o movimento para cuspir."[R4]

Como já dito anteriormente, a alimentação equilibrada é essencial para a recuperação no pós-operatório e, por falta de orientação adequada ou compreensão por parte do paciente, a alimentação foi deficiente para uma parte dos pacientes, que mantinham a dieta líquida com alimentos não nutritivos.

(...) "Eu senti muita falta do arroz e feijão, eu não aguentava mais de ver gelatina na minha frente, de ver danone, ver iogurte, de ver essas coisas... Eu queria arroz e feijão, carne".[R4]

(...) "Você já não aguenta mais ver líquido, líquido, líquido, líquido, sopa, sopa, sopa". [R1]

(...) "Tem as dificuldades na questão da alimentação. (...) Carne, essas coisas, comer um pãozinho francês, nada! Tem que ser tudo mais... é... bem macio".[R1]

Nota-se que é necessário esclarecer aos pacientes que muitos alimentos podem ser batidos, peneirados e que suplementos nutricionais podem ser complementares na dieta. Assim, a variedade do cardápio e melhor aporte calórico podem melhorar a carência alimentar sentida pelos pacientes, bem como diminuir a perda de peso evidenciada no inicio do pósoperatório.

Os exercícios propostos para recuperar a abertura de boca e a função mastigatória fazem parte do pós-operatório e apesar de serem exercícios simples, de mímica facial, ocorrem dificuldades para a realização.

(...) "As orientações foram claras, a dificuldade foi de executar alguns exercícios, né? (...) Você tem os exercícios específicos pra você fazer, pra auxiliar a comunicação e tal e eu acho que o paciente sozinho, pelo menos aconteceu comigo, que eu não conseguia fazer".[R4] 
Não realizar os exercícios pode comprometer uma recuperação eficaz e dentro do prazo esperado, a musculatura precisa se readaptar à nova posição das estruturas ósseas e para isso os exercícios são necessários.

Outro fator comprometedor durante o pós-operatório é que a troca da borracha utilizada no aparelho ortodôntico para guiar a mordida neste momento de recuperação, é realizada pelo paciente, conforme orientação do seu ortodontista. E isso foi colocado como um fator dificultador por um dos pacientes presentes no grupo.

"Eu só tive dificuldade assim na... nas troca de borracha, né, em trocar a borracha".[R2]

O relacionamento social foi apresentado como uma dificuldade vivenciada, pois a face é nosso cartão de visitas e não há como esconder das outras pessoas. O edema facial durante os primeiros dias de pósoperatório chama atenção de quem observa. Explicar aos demais o ocorrido com sua face foi um dos pontos colocados na dificuldade vivenciada.

(...) "Mas o problema, assim (...) é você ter que falar para as pessoas o que que você fez... (...) Minha maior dificuldade foi essa de explicar o que aconteceu... ham... porque que eu fiz, o que eu era, o que eu não era, como é que eu tô e tal." [R5]

Seria importante conscientizar o paciente de que esta fase é parte de um processo e portanto, temporária. Neste período, a opinião dos demais sobre o aspecto visual não deve ser levada em consideração.

\section{Tempo de recuperação da cirurgia e autoimagem}

O tempo prolongado para a recuperação total das funções estomatognáticas é percebido pelos pacientes com ansiedade para ver um resultado final e foi demonstrado como dificuldade neste período.

[...] "Uma coisa que me incomoda muito é a questão da mastigação. Eu ainda não consigo mastigar, eu não tenho o movimento circular, eu só abro e fecho. [...] Eu não consigo beijar, é só selinho. [...] Abrir a boca, você... quando você consegue voltar a comer, você não consegue morder porque a sua boca não abre o suficiente pra você morder". [R4].

[...] "Eu parecia o Homer Simpson, inchadão! [...] Só dormia com gelo... tem aquela bolsa de gel, colocava no-no freezer, enrolava 
na toalha e... e... porque aqui inchou tudo, né? Eu só conseguia dormir com gelo". [R5].

[...] "Você tem esperança de que você desinche depois de um tempo [...] Passou seis meses e não desinchou e, às vezes, você vê uma melhora e quando você encontra alguém, fala assim: 'nossa, mas você não desinchou nada ainda!', né? Então assim, você fala 'mas quando vai parar esse inchaço?." [R3].

A falta de controle para a salivação devido à perda temporária da sensibilidade dos lábios e do mento gera desconforto no convívio com outras pessoas.

(...) "Eu ligava muito mais pra saber quando eu vou parar de babar? Quando esse inchaço vai sair?"[R4]

(...) "O que me incomodava era o fato de você comer na frente dos outros, você tá lá comendo, achando que você tá lindo e tá com a cara toda suja de comida ou de você babar. Era isso que me preocupava, mas não a questão do inchaço. (...) Era mais o fato de você comer ou de você babar na frente dos outros porque você não enxerga, então, quando você vê, a roupa tá toda babada." [R4]

Para outros pacientes estes fatores não interferem no conceito da autoimagem.

(...) "Eu nunca, assim, pensei no que ia me acontecer de momento... de dor, de inchaço, nada disso. Sempre pensei no futuro, por exemplo, no momento como eu ia ser agora que eu to... já operei."[R5]

"Eu não, não tive essa preocupação de me isolar. Eu só não saí logo na primeira semana porque não podia tomar sol." [R4]

Isso demonstra que a autoestima pode influenciar a percepção do paciente perante si mesmo e interferir no relacionamento dele com 0 próximo.

\section{Resultados estéticos do procedimento cirúrgico}

Durante o grupo foi questionada a satisfação com o resultado cirúrgico, e se isso o motivaria a passar por todo o processo novamente. Alguns pacientes denominaram o processo como longo e difícil, sendo um quesito a pensar melhor na hipótese da cirurgia, mas outros, muito satisfeitos, passariam pelo processo novamente para alcançar o resultado desejado. 
(...) "O que eu focava era o... o depois, como ia ser exatamente, o resultado... como ia ser depois. (...) Se eu tivesse que fazer novamente (a cirurgia), eu faria. Não me arrependi em nenhum momento, eu me arrependi de uma coisa, tinha falado pra ela (a médica) fazer logo." [R5]

(...) "Na questão estética, melhorou muito!"[R1]

(...) "Eu não me arrependi. Mas... eu não sei se eu faria de novo". [R4]

(...) "Eu não me arrependo não, né, porque melhorou bastante".[R2]

(...) "Talvez eu também não faria de novo pelo processo, né, pela demora, não pelo resultado".[R3]

Durante o pré-operatório a ansiedade pelo resultado final pode levar o paciente a deixar de lado a importância a ser dada a todo o processo cirúrgico, o tempo que será necessário dedicar para o alcance do resultado final, além de não avaliar a limitação de algumas atividades rotineiras durante o pós-operatório.

(...) "Eu não posso dizer, assim, "o que que você esperava que você fosse ficar?", não dá pra dizer. Eu não sei como eu esperava, eu esperava que ficasse melhor, mas acho que ainda tem a questão do inchaço, então eu não consigo ter essa dimensão". [R4]

(...) "Quando eu falei de... não sei se eu faria de novo porque, embora tenha gostado do resultado... por causa desse processo porque você acha que vai fazer a cirurgia e em 15 dias você tá ótimo, tá bom, sua vida voltou ao normal, tá tudo certo e não é assim, né? (...) É um... processo".[R4]

A idealização do resultado estético também pode causar uma insatisfação frente ao resultado obtido, que pode ser diferente daquele imaginado pelo paciente.

(...)" Apesar de eu ter feito já em março (2010), a dentição
ainda tá bem torta”.[R3] Importância do material educativo

O material educativo foi confirmado pelos pacientes como um facilitador para vivência do pós-operatório. As informações dadas pelo profissional durante a consulta são compreendidas, mas se perdem durante o processo de recuperação ou não foram tomadas como importante no 
primeiro momento da consulta, mas tornam-se fundamentais quando vividas pelos pacientes.

(...) "Eu tinha dúvida com o pós-operatório. (...) Se eu tivesse o material, né, explicado pela enfermeira, tudo direitinho... é... eu acho que o pós-operatório não teria tanta dificuldade que eu tive".[R1]

(...) "Seria bem melhor, ter um livrinho, né? Você ia seguir aquilo.

(...) la facilitar, com certeza." [R2]

(...) "Deu alguma coisa errada, você tem que esperar a próxima consulta pra você passar com o médico pra ele resolver aquele problema, né? Então, tipo assim, se você tem algum... aonde procurar, você já consegue resolver aquele problema mais rápido, mais de imediato".[R3]

(...) "As orientações, assim... o médico, ele passa. (...) Alguma coisa a gente consegue absorver, outras não porque a gente tá tão ansioso! (...) A ansiedade, ela acaba mexendo, né? Então a gente acaba não pegando essas... a gente acaba perdendo essas informações. (...) Então vendo o papel ali ó, tudo escrito, acho que dá pra gente seguir".[R4]

Sendo um método facilitador, o material educativo pode evitar a espera para uma próxima consulta para sanar dúvidas, uma vez que este seja construído com informações de base científica. Pode também diminuir complicações cirúrgicas e a busca de informações na internet.

\section{Momento da entrega do material educativo}

O momento adequado para entrega do material educativo foi questionado aos pacientes, para que seja aproveitado o melhor momento para as orientações serem eficazes.

(...) "Eu acho que antes. A pessoa já tem que saber, já deixar tudo preparado. (...) Acho que deve ser dado antes." [R1]

(...) "É interessante (levar um acompanhante para ouvir as orientações). (...) O meu marido tava junto comigo, né? Tinha feito a cirurgia, então, algumas coisas, assim, que depois você não lembra, ele tava junto e falava "não, ela falou assim", então eu falava pra ele "mas o que que ela falou?". De repente a pessoa tá mais lúcida do que a gente, né?"[R3]

Um consenso entre os pacientes definiu como o melhor momento 0 pré-operatório. Julgou-se importante a presença de um acompanhante durante as orientações para poder auxiliar sua compreensão, uma vez que a 
ansiedade pode levar ao esquecimento do que foi dito e o acompanhante recordaria a informação.

\subsection{QUARTA FASE - CONSTRUÇÃO DO MATERIAL EDUCATIVO E AVALIAÇÃO PELOS JUÍZES}

Nesta fase, a partir dos resultados das fases anteriores e da técnica Delphi, construiu-se o material educativo com validação dessa tecnologia por juízes com conhecimento no atendimento de pacientes submetidos a cirurgia ortognática.

\subsubsection{MATERIAL E MÉTODO}

Após a confecção "prova", o material educativo foi submetido à avaliação de um grupo de dez juízes que atuam no perioperatório de pacientes submetidos à cirurgia ortognática (quatro cirurgiões bucomaxilofaciais, dois enfermeiros, duas fonoaudiólogas e duas nutricionistas) de acordo com a especificidade das informações. O material e o instrumento para avaliação dos juízes (Apêndice E) foi enviado, juntamente com envelope autoadesivo e selado para o retorno do material depois de respondido.

Esta avaliação dos juízes foi realizada por técnica denominada "Delphi", que permite consulta a um grupo de juízes a respeito de eventos futuros, por meio de um questionário, que é repassado continuadas vezes até que seja obtida uma convergência das respostas, um consenso, que representa a consolidação do julgamento intuitivo do grupo ${ }^{117}$.

A técnica surgiu na década de 50 , feita por pesquisadores da Rand Corporation que buscavam em suas pesquisas um método de previsão futura e quando encontraram um método de feedback denominaram-no Delphi. Era baseado no pressuposto de que "duas cabeças pensam melhor do que uma", e se entendia que ter mais opiniões sobre determinado assunto guiava melhor a tomada de decisão ${ }^{118,119}$. 
A técnica ficou esquecida por muitos anos, mas foi retomada em novas áreas como administração, planejamento social, pesquisas e educação. A partir da década de 90, alguns trabalhos na área da enfermagem aplicaram esta técnica, retomada nos atuais trabalhos ${ }^{120,121}$.

A técnica apresenta características essenciais que a tornam facilitadora: anonimato (os juízes não se expõem e assim sentem-se mais livres para opinar), feedback (respostas e pareceres dos juízes, norteando o pesquisador) e flexibilidade (permite liberdade de horários, tempo e local para os juízes responderem ao questionário) ${ }^{118 .}$

O processo da técnica Delphi começa com a elaboração do problema e a escolha dos juízes seguido de um questionário inicial que atua como estratégia de geração de ideias para descobrir o que se diz em relação ao tema do estudo (como um brainstorming). O feedback das respostas é oferecido em uma segunda rodada e um novo questionário é desenvolvido para recolher opiniões sobre o que foi levantado. Uma análise das respostas dos juízes e outras rodadas com as próprias respostas destes são realizadas, de forma a fazê-los refletir e opinar até o consenso aceitável sobre o tema determinado ${ }^{118,122 .}$ A sequência da técnica Delphi é apresentada na figura 11 . 


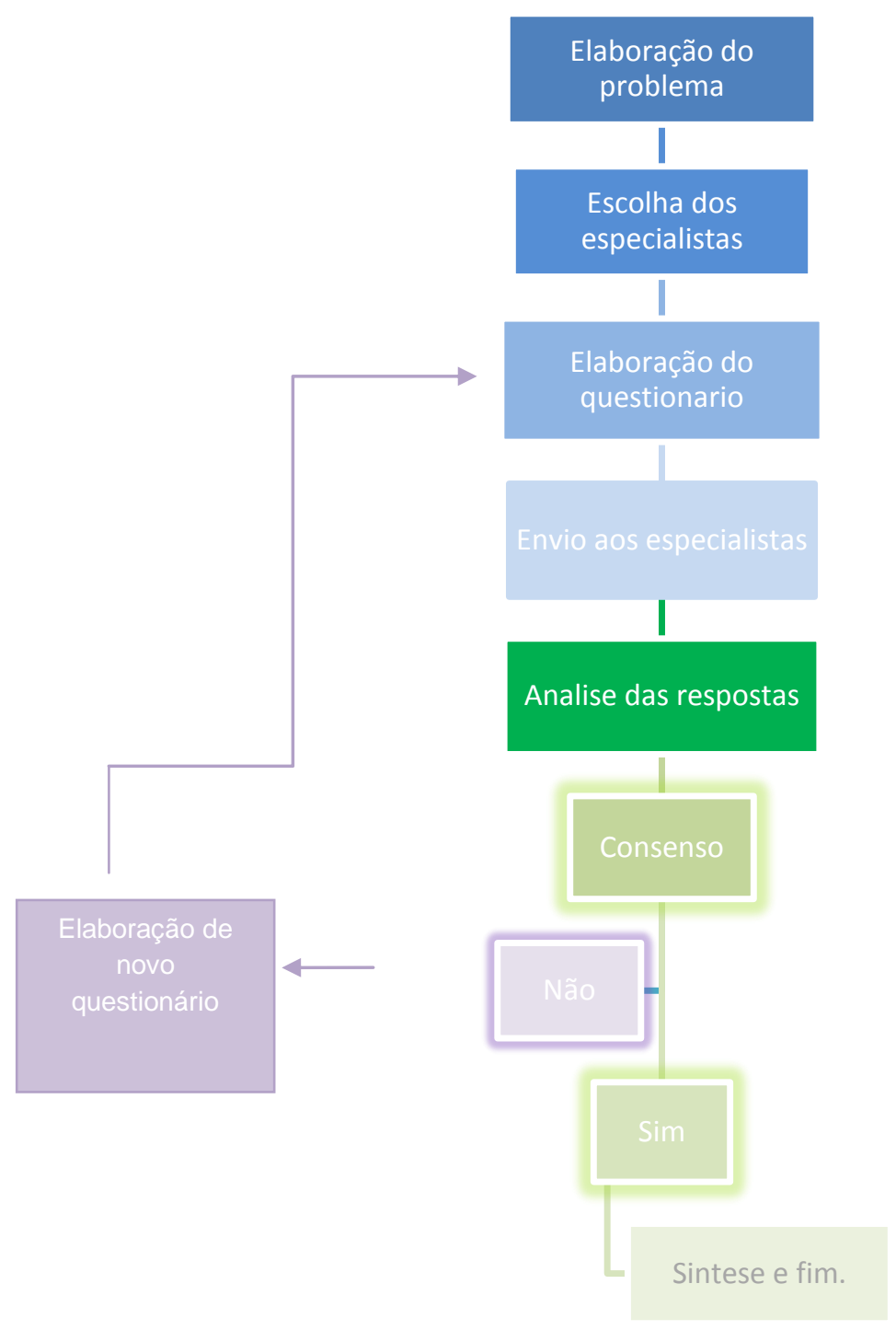

Figura 11 - Sequência da técnica Delphi

Neste estudo foram propostas três rodadas de avaliação: a primeira constituída de uma questão aberta para brainstorming, "o que é importante para orientação do paciente de cirurgia ortognática?"; a segunda, avaliação do material educativo construído com as informações dos blogs, grupo focal e resultado da primeira rodada, quanto à coerência/pertinência, propriedade/clareza e ilustração da informação; a terceira, avaliação final do material após as correções realizadas baseadas nas sugestões da segunda rodada. As rodadas da técnica Delphi aplicadas podem ser visualizadas na figura 12. 


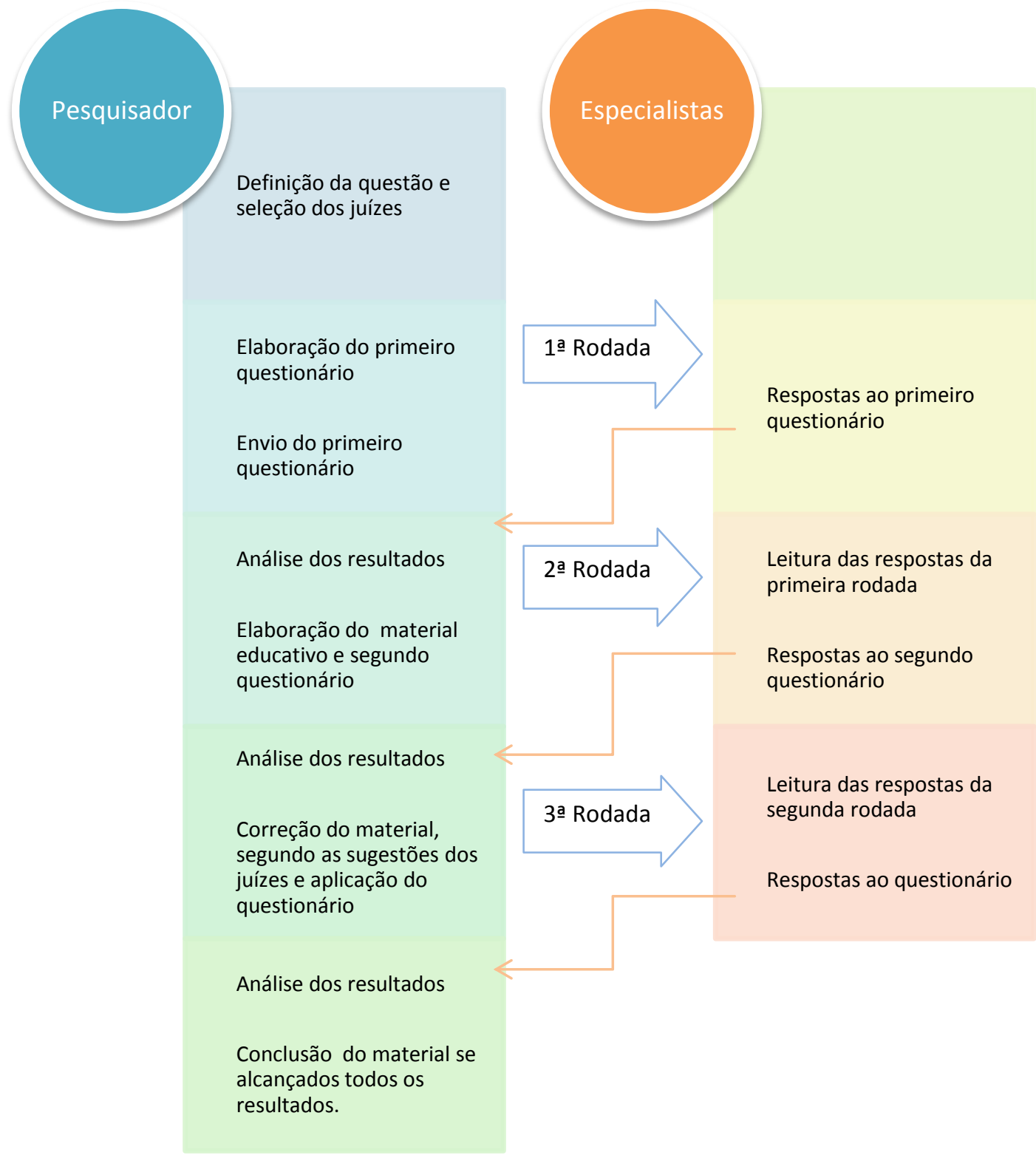

Figura 12 - Apresentação das rodadas propostas com a técnica Delphi

Para cada juiz foi enviado por correio um instrumento para caracterização do grupo com a primeira questão da técnica Delphi e uma carta de apresentação do material educativo (Apêndice C e D).

Após a primeira rodada da Técnica Delphi com os juízes, o material educativo denominado "Cirurgia Ortognática para pacientes" foi construído a partir dos dados relevantes encontrados na revisão de literatura, dos resultados obtidos com o grupo focal e na primeira rodada da técnica Delphi junto aos juízes e na busca em blogs. O programa Microsoft Publisher $\circledast$ foi utilizado para a construção do material, escrito com linguagem simples 
voltada para público leigo (pacientes), seguindo as recomendações para confecção de material educativo citadas na introdução desta pesquisa. As ilustrações foram realizadas por um cartunista para melhorar a compreensão e adesão à leitura.

O material foi impresso em cores em papel Full Color Dupla Face e fixado com dois grampos centrais, dando origem ao formato de revista em formato A5. Este tipo de papel foi escolhido por sua qualidade de impressão gráfica e possibilidade de impressão colorida em ambos os lados, em impressora jato de tinta.

O instrumento elaborado para as avaliações dos juízes após a primeira rodada constituiu-se de 22 itens de avaliação separados em seis categorias (conteúdo, linguagem, ilustrações, leiaute, motivação e cultura) com respostas baseadas na escala Likert, com cinco níveis (discordo totalmente, discordo, não discordo nem concordo, concordo, concordo totalmente) e três questões dissertativas que se referem a erros ou ideias prejudiciais, falta de alguma informação e comentários.

A escala Likert é uma escala de classificação de cinco, sete ou nove pontos, na qual a atitude do entrevistado é medida sobre uma série continua que vai de altamente favorável até altamente desfavorável, com igual número de possibilidades positivas e negativas de respostas e uma categoria média ou neutra. Para o instrumento todo, ou para cada domínio, o escore é calculado pela soma das respostas do usuário dividida pelo número de questões correspondentes ${ }^{123 .}$

Análise de dados. A análise de dados da avaliação dos juízes foi feita com a tabulação dos dados resultantes da técnica Delphi. Utilizou-se a estatística descritiva pela análise das medidas de tendência central: média, mediana e extremos para questões que abordam valores (porcentagem de utilização de uma técnica, relevância de uma atitude). Para as questões que indicam votação pode-se apresentar a distribuição de frequência das respostas por quantidade ou percentil ${ }^{117}$. 


\subsubsection{RESULTADOS}

\subsubsection{CARACTERIZAÇÃO DOS JUÍZES}

O instrumento aplicado na primeira fase da técnica Delphi permitiu caracterizar os juízes que participaram desta pesquisa. Os dados de identificação destes profissionais foram reunidos conforme as seguintes variáveis: profissão, idade, sexo, área de trabalho, tempo de formação (quadro 5.6).

Quadro 5.6 - Identificação dos juízes segundo sexo, idade, área de trabalho e tempo de formação profissional. São Paulo, 2001.

\begin{tabular}{|l|c|c|l|c|}
\hline Profissão & Idade & Sexo & Área de trabalho & $\begin{array}{c}\text { Tempo de } \\
\text { formação } \\
\text { (em anos) }\end{array}$ \\
\hline Cirurgião Bucomaxilo & 38 & $\mathrm{M}$ & Consultório / Hospitalar & 14 \\
\hline Cirurgião Bucomaxilo & 31 & $\mathrm{M}$ & Consultório / Hospitalar & 5 \\
\hline Cirurgião Bucomaxilo & 45 & $\mathrm{M}$ & Consultório / Hospitalar & 22 \\
\hline Cirurgiã Bucomaxilo & 36 & $\mathrm{~F}$ & Consultório / Hospitalar & 13 \\
\hline Enfermeira & 39 & $\mathrm{~F}$ & Centro cirúrgico & 6 \\
\hline Enfermeira & 32 & $\mathrm{~F}$ & Centro cirúrgico & 7 \\
\hline Nutricionista & 25 & $\mathrm{~F}$ & Hospitalar (área clínica) & 2 \\
\hline Nutricionista & 23 & $\mathrm{~F}$ & Hospitalar (área clínica) & 1 \\
\hline Fonoaudióloga & 32 & $\mathrm{~F}$ & Consultório & 6 \\
\hline Fonoaudióloga & 37 & $\mathrm{~F}$ & $\begin{array}{l}\text { Consultório/ } \\
\text { Universidade }\end{array}$ & 13 \\
\hline
\end{tabular}

Com exceção das nutricionistas, a maioria dos juízes tinha cinco anos ou mais de experiência profissional.

Ao avaliar as variáveis da caracterização dos juízes, nota-se que a maioria dos participantes é do sexo feminino, o que é comum na área da saúde. 
As idades dos participantes foram apresentadas por medidas de tendência central, de acordo com a profissão (tabela 5.3). As idades dos juízes refletem o tempo de formação profissional.

Tabela 5.3 - Distribuição dos juízes segundo a profissão e medidas descritivas da variável idade. São Paulo. 2011

\begin{tabular}{llccccc}
\hline Profissão & N & Média & $\begin{array}{c}\text { Desvio } \\
\text { padrão }\end{array}$ & Mínimo & Mediana & Máximo \\
Cirurgião & 4 & 37,5 & 5,8 & 31 & 37 & 45 \\
Enfermeira & 2 & 35,5 & 4,9 & 32 & 35,5 & 39 \\
Nutricionista & 2 & 24,0 & 1,4 & 23,0 & 24,0 & 25 \\
Fonoaudióloga & 2 & 34,5 & 3,5 & 32 & 34,5 & 37 \\
Total & 10 & & & & & \\
\hline
\end{tabular}

Um número maior de cirurgiões como juízes foi requerido pela demanda de informação necessária destes profissionais para construção do material educativo. As nutricionistas apresentaram uma idade média menor que os demais profissionais.

A variável tempo de formação relacionada à profissão é apresentada na tabela 5.4.

Tabela 5.4 - Distribuição de juízes segundo profissão e medidas descritivas da variável tempo de formação. São Paulo. 2011

\begin{tabular}{llccccc}
\hline Profissão & N & Média & $\begin{array}{c}\text { Desvio } \\
\text { padrão }\end{array}$ & Mínimo & Mediana & Máximo \\
Cirurgião & 4 & 13,5 & 6,9 & 5 & 13,5 & 22 \\
Enfermeira & 2 & 6,5 & 0,7 & 6 & 6,5 & 7 \\
Nutricionista & 2 & 1,5 & 0,7 & 1 & 1,5 & 2 \\
Fonoaudióloga & 2 & 9,5 & 4,9 & 6 & 9,5 & 13 \\
Total & 10 & & & & & \\
\hline
\end{tabular}


O tempo de formação dos profissionais apresenta variação de 1 a 22 anos. O maior tempo de formação está para os cirurgiões seguidos da fonoaudióloga, enfermeira e nutricionista.

A titulação é uma variável importante para demonstrar a capacitação dos juízes escolhidos, e a mesma é apresentada na tabela 5.5.

\begin{tabular}{|c|c|c|c|c|c|}
\hline \multirow[t]{2}{*}{ Titulação } & \multicolumn{4}{|c|}{ Profissão } & \multirow[t]{2}{*}{ Total } \\
\hline & Cirurgião & Enfermeira & Nutricionista & Fonoaudióloga & \\
\hline Doutorado & - & - & - & 2 & 2 \\
\hline Mestrado & 1 & - & - & - & 1 \\
\hline Especialização & 3 & 2 & 1 & - & 6 \\
\hline $\begin{array}{l}\text { Apenas } \\
\text { Graduação }\end{array}$ & - & - & 1 & - & 1 \\
\hline Total & 4 & 2 & 2 & 2 & 10 \\
\hline
\end{tabular}

A maioria dos profissionais possuía especialização demonstrando interesse em aprimoramento/capacitação para melhor atendimento em sua área profissional.

\subsubsection{PRIMEIRA RODADA DA TÉCNICA DELPHI}

A primeira questão aplicada na metodologia da técnica Delphi consistiu em uma pergunta aberta "O que é importante para orientação do paciente de cirurgia ortognática?", com o intuito de promover um brainstorming sobre a opinião dos juízes.

Com juízes de diferentes aéreas profissionais, as respostas encontradas abordaram diversos itens. Alguns foram descritos mais de uma vez, outros colocados de forma generalizada por um profissional e mais detalhados por outro. Os resultados da primeira fase da técnica Delphi são apresentados no quadro 5.7 . 
Quadro 5.7 - Distribuição das respostas da primeira fase da técnica Delphi

\begin{tabular}{|c|c|}
\hline Orientação do profissional & $\begin{array}{c}\text { № } \\
\text { repetições }\end{array}$ \\
\hline Higiene oral rigorosa & 7 \\
\hline Parestesia & 4 \\
\hline Edema facial & 4 \\
\hline Dificuldade respiratória e mastigatória & 4 \\
\hline Alteração da voz e movimentos musculares pós-operatório & 4 \\
\hline Dieta líquida & 3 \\
\hline Uso de elásticos inter-oclusão & 2 \\
\hline Uso de compressas de gelo (reduzir edema / hematoma) & 2 \\
\hline Riscos inerentes ao procedimento & 2 \\
\hline Possíveis sequelas e intercorrências no intraoperatório & 2 \\
\hline Padrão de mastigação e deglutição & 2 \\
\hline Mudança do perfil facial & 2 \\
\hline Hematoma & 2 \\
\hline Dor & 2 \\
\hline Dificuldade de abertura de boca & 2 \\
\hline Dieta equilibrada & 2 \\
\hline Descrição do tipo de anestesia (geral) & 2 \\
\hline Alimentação leve por 2 meses (sem alimentos duros) & 2 \\
\hline Afastamento do trabalho por tempo determinado & 2 \\
\hline Uso de lubrificante labial & 1 \\
\hline Uso de escova de cerdas macias para higiene oral & 1 \\
\hline Uso de descongestionantes nasais & 1 \\
\hline Sangramentos & 1 \\
\hline Risco de infecção & 1 \\
\hline Retorno ambulatorial por 30 dias & 1 \\
\hline Quebra da expectativa em relação a estética & 1 \\
\hline Postura da cabeça, corpo, lábios e língua & 1 \\
\hline
\end{tabular}


Continuação

\begin{tabular}{|l|c|}
\hline Orientação do profissional & $\begin{array}{c}\text { No } \\
\text { repetições }\end{array}$ \\
\hline Possível perda de peso & 1 \\
\hline Possibilidade de náuseas / vômitos / constipação & 1 \\
\hline Orientar tempo cirúrgico previsto & 1 \\
\hline Orientar quanto a recuperação anestésica & 1 \\
\hline Orientar jejum absoluto & 1 \\
\hline Orientação em relação a continuidade do aparelho ortodôntico & 1 \\
\hline Necessidade de procedimentos adicionais & 1 \\
\hline Necessidade de avaliação pós-operatória & 1 \\
\hline Não assoar o nariz & 1 \\
\hline Motivo das possíveis alterações da voz (de caráter transitório) & 1 \\
\hline Importância da documentação e guia cirúrgico (preparo & 1 \\
\hline cirúrgico) & 1 \\
\hline Exposição ao sol após 4 meses & 1 \\
\hline Estratégias de comunicação e aprimoramento da fala & 1 \\
\hline Dificuldade de aceitação dos familiares & 1 \\
\hline Deiscência da sutura & 1 \\
\hline Cabeceira elevada para redução do edema & 1 \\
\hline Alteração temporária da audição & 1 \\
\hline & 1 \\
\hline
\end{tabular}

Esta primeira fase tinha o intuito de obter conhecimento sobre o que os juízes acreditavam ser importante informar ao paciente durante 0 tratamento da cirurgia ortognática.

Para construção do material educativo era fundamental conhecer a visão do que o especialista considera importante. Nem sempre o que o profissional considera importante é o que o paciente deseja saber, por isso, a importância de conhecer a percepção de ambas as partes.

Os resultados atingiram o objetivo proposto desta primeira fase e nortearam o pesquisador a construir a primeira prova do material educativo. Notou-se que a higiene oral foi o item mais recomendado pelos juízes, citado 
por cirurgiões, enfermeiras e fonoaudiólogas $(70 \%)$. De todos os itens mencionados (44), 25 (56,8\%) foram mencionados apenas uma vez.

Os itens do brainstorming agrupados por categorias (orientação préoperatória; orientação pós-operatória e complicações cirúrgicas) foram distribuídos no quadro a seguir.

Quadro 5.8 - Distribuição das respostas da primeira fase da técnica Delphi separadas por categoria

\begin{tabular}{|c|c|c|}
\hline $\begin{array}{c}\text { Orientação pré- } \\
\text { operatória }\end{array}$ & $\begin{array}{c}\text { Orientação pós- } \\
\text { operatória }\end{array}$ & $\begin{array}{l}\text { Complicações } \\
\text { cirúrgicas }\end{array}$ \\
\hline $\begin{array}{l}\text { Riscos inerentes ao } \\
\text { procedimento }\end{array}$ & Higiene oral rigorosa & Parestesia \\
\hline $\begin{array}{l}\text { Possíveis sequelas e } \\
\text { intercorrências no } \\
\text { intraoperatório }\end{array}$ & Dieta líquida & Edema facial \\
\hline Mudança do perfil facial & $\begin{array}{l}\text { Uso de elásticos inter- } \\
\text { oclusão }\end{array}$ & $\begin{array}{l}\text { Dificuldade } \\
\text { respiratória e } \\
\text { mastigatória }\end{array}$ \\
\hline $\begin{array}{l}\text { Dificuldade de abertura } \\
\text { de boca }\end{array}$ & $\begin{array}{l}\text { Uso de compressas de } \\
\text { gelo (reduzir edema / } \\
\text { hematoma) }\end{array}$ & $\begin{array}{l}\text { Alteração da voz e } \\
\text { movimentos } \\
\text { musculares pós- } \\
\text { operatório }\end{array}$ \\
\hline $\begin{array}{l}\text { Descrição do tipo de } \\
\text { anestesia (geral) }\end{array}$ & $\begin{array}{l}\text { Padrão de mastigação e } \\
\text { deglutição }\end{array}$ & Hematoma \\
\hline $\begin{array}{l}\text { Afastamento do trabalho } \\
\text { por tempo determinado }\end{array}$ & Dieta equilibrada & Dor \\
\hline Risco de infecção & $\begin{array}{l}\text { Alimentação leve por } 2 \\
\text { meses (sem alimentos } \\
\text { duros) }\end{array}$ & Sangramentos \\
\hline $\begin{array}{l}\text { Quebra da expectativa } \\
\text { em relação à estética }\end{array}$ & Uso de lubrificante labial & $\begin{array}{l}\text { Deiscência da } \\
\text { sutura }\end{array}$ \\
\hline
\end{tabular}


Continuação

\begin{tabular}{|c|c|c|}
\hline $\begin{array}{l}\text { Orientação pré- } \\
\text { operatória }\end{array}$ & $\begin{array}{l}\text { Orientação pós- } \\
\text { operatória }\end{array}$ & $\begin{array}{l}\text { Complicações } \\
\text { cirúrgicas }\end{array}$ \\
\hline $\begin{array}{l}\text { Retorno ambulatorial por } \\
30 \text { dias }\end{array}$ & $\begin{array}{l}\text { Uso de escova de cerdas } \\
\text { macias para higiene oral }\end{array}$ & \\
\hline Possível perda de peso & $\begin{array}{l}\text { Uso de } \\
\text { descongestionantes } \\
\text { nasais }\end{array}$ & \\
\hline $\begin{array}{l}\text { Possibilidade de náuseas } \\
\text { / vômitos / constipação }\end{array}$ & $\begin{array}{l}\text { Postura da cabeça, corpo, } \\
\text { lábios e língua }\end{array}$ & \\
\hline $\begin{array}{l}\text { Orientar tempo cirúrgico } \\
\text { previsto }\end{array}$ & $\begin{array}{l}\text { Orientação em relação a } \\
\text { continuidade do aparelho } \\
\text { ortodôntico }\end{array}$ & \\
\hline $\begin{array}{l}\text { Orientar quanto a } \\
\text { recuperação anestésica }\end{array}$ & $\begin{array}{l}\text { Necessidade de avaliação } \\
\text { pós-operatória }\end{array}$ & \\
\hline Orientar jejum absoluto & Não assoar o nariz & \\
\hline $\begin{array}{l}\text { Necessidade de } \\
\text { procedimentos adicionais }\end{array}$ & $\begin{array}{l}\text { Exposição ao sol após } 4 \\
\text { meses }\end{array}$ & \\
\hline $\begin{array}{l}\text { Motivo das possíveis } \\
\text { alterações da voz (de } \\
\text { caráter transitório) }\end{array}$ & $\begin{array}{l}\text { Estratégias de } \\
\text { comunicação e } \\
\text { aprimoramento da fala }\end{array}$ & \\
\hline $\begin{array}{l}\text { Importância da } \\
\text { documentação e guia } \\
\text { cirúrgico (preparo } \\
\text { cirúrgico) }\end{array}$ & $\begin{array}{l}\text { Cabeceira elevada para } \\
\text { redução do edema }\end{array}$ & \\
\hline \multicolumn{3}{|l|}{$\begin{array}{l}\text { Dificuldade de aceitação } \\
\text { dos familiares }\end{array}$} \\
\hline $\begin{array}{l}\text { Alteração temporária da } \\
\text { audição }\end{array}$ & & \\
\hline
\end{tabular}

A categoria de orientação pré-operatória consiste no maior número de itens, sendo responsável por $43 \%$ (19) das sugestões dos juízes. A orientação pós-operatória consiste em $38 \%$ (17) das sugestões e as complicações apenas $18 \%(8)$. 


\subsubsection{SEGUNDA RODADA DA TÉCNICA DELPHI}

De posse do material resultante do brainstorming dos juízes, dos resultados da revisão de literatura sobre o assunto e do levantamento de necessidade de informações junto a pacientes no grupo focal e pesquisa nos blogs e comunidades virtuais com pacientes internautas e reunindo todo $o$ material de coleta de dados, procedeu-se à elaboração do material educativo.

A segunda rodada da técnica Delphi consistiu no envio do material educativo aos juízes e seus resultados derivaram da leitura e posterior preenchimento do instrumento enviado (Apêndice E).

Este instrumento com 22 itens separados em seis grupos de avaliação (conteúdo, linguagem, ilustrações, leiaute, motivação, cultura) foi composto por níveis de variação da escala Likert: discordo totalmente, discordo, não discordo nem concordo, concordo e concordo totalmente.

Aos 10 juízes foi dado o prazo de 10 dias para envio da sua avaliação sobre o material educativo. O prazo estabelecido somente foi cumprido por três juízes. Após 20 dias do envio do material, o pesquisador enviou aos juízes faltantes um e-mail solicitando o instrumento enviado e obteve retorno de três juízes. Dois outros juízes referiram ter perdido o material enviado e novo material foi enviado a esses profissionais.

Após 30 dias depois do envio do material, dois juízes enviaram sua resposta, e ao completar 40 dias do envio, os dois juízes que haviam perdido o material conseguiram enviar a resposta.

O atraso na obtenção dos resultados aumentou o tempo determinado para esta atividade e consequentemente atrasou o prazo estabelecido para a terceira rodada, mas não inviabilizou o processo de realização desta.

Os resultados obtidos com o instrumento foram analisados de forma quantitativa, por meio dos itens do instrumento de coleta de dados, e mantidos na mesma sequência de grupos de avaliação do instrumento. A 
tabela a seguir apresenta a análise dos resultados obtidos com 0 instrumento aplicado aos juízes por níveis de variação da escala Likert. 
Tabela 5.6 - Distribuição da frequência absoluta de escores obtidos por juízes segundo os itens do instrumento na segunda rodada da técnica Delphi. São Paulo. 2011

\begin{tabular}{|c|c|c|c|c|c|c|}
\hline \multirow[b]{2}{*}{ Itens } & \multicolumn{6}{|c|}{ Escores } \\
\hline & $\begin{array}{l}\text { Discordo } \\
\text { totalmente }\end{array}$ & Discordo & $\begin{array}{c}\text { Não } \\
\text { discordo } \\
\text { nem } \\
\text { concordo }\end{array}$ & Concordo & $\begin{array}{l}\text { Concordo } \\
\text { totalmente }\end{array}$ & Amostra \\
\hline \multicolumn{7}{|l|}{ Conteúdo } \\
\hline 1.1 O conteúdo está apropriado ao público alvo & - & - & - & 4 & 6 & 10 \\
\hline 1.2 A divisão dos títulos e subtítulos do material é pertinente & - & - & - & 3 & 7 & 10 \\
\hline $\begin{array}{l}\text { 1.3 Os trechos chave (trechos em destaque) são pontos importantes e merecem } \\
\text { destaque }\end{array}$ & - & - & - & 2 & 8 & 10 \\
\hline $1.4 \mathrm{O}$ conteúdo é suficiente para atender às necessidades do público alvo & - & - & 1 & 4 & 5 & 10 \\
\hline 1.5 A sequência do texto é lógica & - & - & - & 4 & 6 & 10 \\
\hline Subtotal em porcentagem & - & - & $2 \%$ & $34 \%$ & $64 \%$ & $100 \%$ \\
\hline \multicolumn{7}{|l|}{ Linguagem } \\
\hline 2.1 O estilo da redação é compatível com o público alvo & - & - & - & 5 & 5 & 10 \\
\hline 2.2 A escrita utilizada é atrativa & - & - & - & 6 & 4 & 10 \\
\hline 2.3 A linguagem é clara e objetiva & - & - & - & 4 & 6 & 10 \\
\hline Subtotal em porcentagem & - & - & - & $50 \%$ & $50 \%$ & $100 \%$ \\
\hline \multicolumn{7}{|l|}{ llustrações } \\
\hline $\begin{array}{l}\text { 3.1 As ilustrações utilizadas são pertinentes com o conteúdo do material e } \\
\text { elucidam o conteúdo }\end{array}$ & - & - & - & 3 & 7 & 10 \\
\hline 3.2 As ilustrações são claras e transmitem facilidade de compreensão & - & - & - & 3 & 7 & 10 \\
\hline $\begin{array}{l}\text { 3.3 As legendas aplicadas às imagens estão adequadas e auxilia o leitor } \\
\text { compreender a imagem }\end{array}$ & - & - & - & 3 & 7 & 10 \\
\hline $\begin{array}{l}\text { 3.4 A quantidade de ilustrações está adequada para o conteúdo do material } \\
\text { educativo }\end{array}$ & - & - & - & 6 & 4 & 10 \\
\hline Subtotal em porcentagem & $=$ & $=$ & - & $37,5 \%$ & $62,5 \%$ & $100 \%$ \\
\hline
\end{tabular}


Continuação

\begin{tabular}{|c|c|c|c|c|c|c|}
\hline \multirow[b]{2}{*}{ Itens } & \multicolumn{6}{|c|}{ Escores } \\
\hline & $\begin{array}{l}\text { Discordo } \\
\text { totalmente }\end{array}$ & Discordo & $\begin{array}{c}\text { Não } \\
\text { discordo } \\
\text { nem } \\
\text { concordo }\end{array}$ & Concordo & $\begin{array}{l}\text { Concordo } \\
\text { totalmente }\end{array}$ & Amostra \\
\hline \multicolumn{7}{|l|}{ Leiaute } \\
\hline 4.1 O tipo de letra utilizado facilita a leitura & - & - & - & 2 & 8 & 10 \\
\hline $\begin{array}{l}4.2 \text { As cores aplicadas ao texto são pertinentes e facilitadoras para a } \\
\text { leitura }\end{array}$ & - & - & - & 3 & 7 & 10 \\
\hline 4.3 A composição visual está atrativa e bem organizada & - & - & - & 4 & 6 & 10 \\
\hline $\begin{array}{l}\text { 4.4 O formato (tamanho) do material educativo e o número de páginas } \\
\text { está adequado }\end{array}$ & - & - & - & 5 & 5 & 10 \\
\hline 4.5 A disposição do texto está adequada & - & - & - & 5 & 5 & 10 \\
\hline 4.6 O tamanho das letras dos títulos, subtítulos e texto é adequado & - & - & - & 4 & 6 & 10 \\
\hline Subtotal em porcentagem & - & - & $=$ & $38,3 \%$ & $61,7 \%$ & $100 \%$ \\
\hline \multicolumn{7}{|l|}{ Motivação } \\
\hline 5.1 O conteúdo está motivador e incentiva prosseguir com a leitura & - & - & - & 3 & 7 & 10 \\
\hline 5.2 O conteúdo despertou interesse do leitor & - & - & - & 3 & 7 & 10 \\
\hline $\begin{array}{l}5.3 \text { O conteúdo atende às dúvidas, esclarece e educa o paciente } \\
\text { durante o pós-operatório }\end{array}$ & - & - & - & 3 & 7 & 10 \\
\hline Subtotal em porcentagem & - & - & $=$ & $30 \%$ & $70 \%$ & $100 \%$ \\
\hline \multicolumn{7}{|l|}{ Cultura } \\
\hline $\begin{array}{l}\text { 6.1 O texto está compatível com o público alvo, atendendo aos } \\
\text { diferentes perfis de pacientes (maior ou menor entendimento) }\end{array}$ & - & - & - & 5 & 5 & 10 \\
\hline Subtotal em porcentagem & - & - & $=$ & $50 \%$ & $50 \%$ & $100 \%$ \\
\hline Total (22 itens) & - & - & 1 & 84 & 135 & \\
\hline Total em porcentagem & $0 \%$ & $0 \%$ & $0,5 \%$ & $38,2 \%$ & $61,3 \%$ & \\
\hline
\end{tabular}


Nesta escala para cada categoria, se todos os juízes respondessem apenas a nível da escala Likert, teríamos a somatória de 50 respostas para conteúdo, 30 para linguagem, 40 para ilustrações, 60 para leiaute, 30 para motivação e 10 para cultura, totalizando 220 respostas.

Como demonstra a tabela 5.6, os juízes tiveram tendência concordante com o material educativo apresentado. Ao analisar os itens, obtivemos (1) não discorda nem concorda, (84) concorda e (135) concorda totalmente. A discordância não foi encontrada em nenhum dos itens.

Uma análise por categoria demonstra que nos itens que se referem a conteúdo, 2\% (1) não discordaram nem concordaram, 34\% (17) concordaram e 64\% (32) concordaram totalmente. Portanto, das 50 (100\%) opções das respostas, 64\% concordaram totalmente, o que demonstra aceitação dos juízes para o conteúdo apresentado.

No item linguagem, 50\% (15) concordaram e 50\% (15) concordaram totalmente. Embora com $100 \%$ de concordância, as diferenças obtidas segundo a qualificação positiva da concordância permitem um questionamento: os juízes julgaram desta forma porque acreditam que o paciente não compreenderia ou por não terem conhecimento aprofundado sobre métodos de escrita? Com isso, ficou este item para reavaliação na terceira rodada da técnica Delphi ou, posteriormente, na avaliação com o paciente.

Em ilustrações, 37,5\% (15) concordaram e 62,5\% (25) concordaram totalmente. Foi alcançado 62,5\% para concordo totalmente, demonstrando pertinência nas ilustrações inseridas no material educativo.

Leiaute representa a categoria com maior número de itens. Seriam 60 (100\%) opções de respostas e para esta categoria 38,3\% (23) concordaram e $61,7 \%$ (37) concordaram totalmente. Pode-se dizer que o leiaute do material educativo foi aprovado pelos juízes.

A motivação apresenta 30\% (9) concordaram e 70\% (21) concordaram totalmente. As opções de resposta correspondem a 30 (100\%) e um elevado índice $(70 \%)$ foi alcançado, demonstrando que o material foi motivador no 
processo do cuidado. Pode-se dizer que os juízes o julgam importante para a recuperação do paciente.

A categoria cultura composta de apenas um item representa 10 (100\%) opções de resposta e obteve-se 50\% (5) de concorda e 50\% (5) de concorda totalmente, resultando em aprovação do material para a nossa cultura brasileira.

Uma discussão mais ampla sobre os resultados de cada categoria ficou reservada à terceira rodada onde um comparativo entre os resultados de ambas as rodadas pode ser realizado.

Uma segunda análise de dados foi proposta, em busca de análise das variáveis da escala Likert por juiz (denominado o especialista (E) seguido do número do avaliador). Estes dados estatísticos proporcionam outra visão dos resultados e foram distribuídos na tabela 5.7 a seguir. 


\begin{tabular}{|c|c|c|c|c|c|c|c|c|c|c|c|}
\hline \multirow{2}{*}{ Variáveis da Escala Likert } & & \multicolumn{10}{|c|}{ Juízes } \\
\hline & & E1 & E2 & E3 & E4 & E5 & E6 & E7 & E8 & E9 & E10 \\
\hline \multirow{3}{*}{ Discordo totalmente } & $\mathbf{S}$ & - & - & - & - & - & - & - & - & - & - \\
\hline & $\mathbf{M}$ & - & - & - & - & - & - & - & - & - & - \\
\hline & $\%$ & - & - & - & - & - & - & - & - & - & - \\
\hline \multirow{3}{*}{ Discordo } & $\mathbf{S}$ & - & - & - & - & - & - & - & - & - & - \\
\hline & $\mathbf{M}$ & - & - & - & - & - & - & - & - & - & - \\
\hline & $\%$ & - & - & - & - & - & - & - & - & - & - \\
\hline \multirow{4}{*}{ Não discordo nem concordo } & $\mathbf{s}$ & - & 1 & - & - & - & - & - & - & - & - \\
\hline & $\mathbf{M}$ & - & 0,1 & - & - & - & - & - & - & - & - \\
\hline & & & & & & & & & & & \\
\hline & $\%$ & - & 4,6 & - & - & - & - & - & - & - & - \\
\hline \multirow{3}{*}{ Concordo } & $\mathbf{S}$ & 7 & 21 & - & 13 & 9 & 6 & - & - & 19 & 9 \\
\hline & $\mathbf{M}$ & 0,3 & 1,0 & - & 0,6 & 0,4 & 0,3 & - & - & 0,9 & 0,4 \\
\hline & $\%$ & 31,8 & 95,5 & - & 59,1 & 40,9 & 27,3 & - & - & 86,4 & 40,9 \\
\hline \multirow{3}{*}{ Concordo totalmente } & $\mathbf{s}$ & 15 & - & 22 & 9 & 13 & 16 & 22 & 22 & 3 & 13 \\
\hline & $\mathbf{M}$ & 0,7 & - & 1 & 0,4 & 0,6 & 0,7 & 1 & 1 & 0,1 & 0,6 \\
\hline & $\%$ & 68,2 & - & 100 & 40,9 & 59,1 & 72,7 & 100 & 100 & 13,6 & 59,1 \\
\hline
\end{tabular}


Se colocada uma meta de $70 \%$ de itens favoráveis da escala Likert, observa-se que $20 \%$ (2) dos juízes atingiram pontuação acima de $70 \%$ nos itens concordo e $40 \%$ (4) atingiram a mesma pontuação no item concordo totalmente. Os demais $30 \%$ (3) não atingiram, porém mantiveram mais respostas no concordo totalmente e 10\% (1) não atingiu a meta e manteve-se no concordo.

Apesar do nível concordo da escala Likert já demonstrar resultado positivo, um melhor resultado pode ser alcançado quando o nível concordo totalmente da escala apresentar maiores concordâncias entre os juízes.

Após a escala Likert, o instrumento apresentava três questões dissertativas relacionadas a indagações de erros ou ideias pouco claras no material educativo; informação não encontrada no material e comentários. Os dados quantitativos dessas respostas são apresentados a seguir e uma análise qualitativa foi realizada a partir das respostas colocadas pelos juízes.

Tabela 5.8 - Dados quantitativos referente às questões dissertativas do instrumento. São Paulo. 2011

\begin{tabular}{ccccc}
\hline Questões & $\begin{array}{c}\text { N. de } \\
\text { itens } \\
\text { citados }\end{array}$ & $\begin{array}{c}\text { N. de juízes } \\
\text { por } \\
\text { questão }\end{array}$ & $\begin{array}{c}\text { Média de } \\
\text { itens por } \\
\text { juiz }\end{array}$ & $\begin{array}{c}\text { Porcentagem de } \\
\text { juízes por questão }\end{array}$ \\
\hline $\begin{array}{c}\text { Erros / ideias } \\
\text { Falta de }\end{array}$ & 17 & 6 & 2,8 & $60,0 \%$ \\
informações & 9 & 5 & 1,8 & $50,0 \%$ \\
\hline Comentários & 8 & 8 & 1,0 & $80,0 \%$ \\
\hline
\end{tabular}

$\mathrm{Na}$ análise qualitativa das respostas abertas, a primeira questão indagava ao juiz se ele havia notado algum equívoco na redação do material educativo. Os resultados obtidos contribuíram para alterações no texto. Essas sugestões colocadas pelos juízes são apresentadas a seguir com a alteração realizada após análise do juiz. (quadro 5.9). 
Quadro 5.9 - Alterações realizadas no material educativo após avaliação dos juízes na segunda rodada da técnica Delphi

\begin{tabular}{|c|c|c|}
\hline Frase original & Sugestão juiz & Alteração realizada \\
\hline $\begin{array}{l}\text { Depende da cirurgia, da } \\
\text { técnica aplicada. Mas, } \\
\text { observe um exemplo... }\end{array}$ & $\begin{array}{l}\text { As fixações podem ser } \\
\text { diferentes }\end{array}$ & $\begin{array}{l}\text { As fixações podem ser } \\
\text { diferentes e dependem } \\
\text { da cirurgia. Observe } \\
\text { exemplo de como } \\
\text { podem ser colocadas as } \\
\text { fixações }\end{array}$ \\
\hline $\begin{array}{l}\text { Jejum (inclusive de } \\
\text { água) }\end{array}$ & Jejum de 8h no mínimo & $\begin{array}{l}\text { Jejum de 8h (inclusive } \\
\text { de água) }\end{array}$ \\
\hline $\begin{array}{l}\text { Os cortes são gerados } \\
\text { dentro de sua boca, } \\
\text { portanto não haverá } \\
\text { cicatrizes em sua face }\end{array}$ & $\begin{array}{l}\text { Às vezes pode haver } \\
\text { cicatrizes }\end{array}$ & $\begin{array}{l}\text { Os cortes geralmente } \\
\text { são realizados dentro de } \\
\text { sua boca e, neste caso, } \\
\text { não haverá cicatrizes } \\
\text { em sua face. Se for } \\
\text { preciso algum corte } \\
\text { externo, pode haver } \\
\text { cicatrizes }\end{array}$ \\
\hline $\begin{array}{l}\text {....poderá sentir muito } \\
\text { sono (efeito da } \\
\text { anestesia), poderá falar } \\
\text { e se alimentar... }\end{array}$ & $\begin{array}{l}\text { A informação de que o } \\
\text { paciente pode se } \\
\text { alimentar pode gerar a } \\
\text { sensação de que seria } \\
\text { qualquer tipo de } \\
\text { alimento. }\end{array}$ & $\begin{array}{l}\text {...poderá sentir muito } \\
\text { sono (efeito da } \\
\text { anestesia), poderá falar } \\
\text { e ingerir líquidos... }\end{array}$ \\
\hline $\begin{array}{l}\text { Normalmente não vai } \\
\text { ser assim pra sempre, é } \\
\text { apenas por um período }\end{array}$ & $\begin{array}{l}\text { Substituir "normalmente } \\
\text { não vai ser assim" por } \\
\text { "como não vai...." ou } \\
\text { retirar e deixar "é } \\
\text { apenas por um período" }\end{array}$ & $\begin{array}{l}\text { Mas, isto será apenas } \\
\text { por um período }\end{array}$ \\
\hline $\begin{array}{l}\text { Você pode notar } \\
\text { formigamento na região } \\
\text { da mandíbula, do nariz, } \\
\text { lábio e queixo.... }\end{array}$ & $\begin{array}{l}\text { Alterações de } \\
\text { sensibilidade também no } \\
\text { palato }\end{array}$ & $\begin{array}{l}\text { Você pode notar } \\
\text { formigamento na região } \\
\text { da mandíbula, palato, } \\
\text { nariz, lábio e queixo.... }\end{array}$ \\
\hline $\begin{array}{l}\text { Infecção é rara nesta } \\
\text { cirurgia }\end{array}$ & $\begin{array}{l}\text { Ferida cirúrgica } \\
\text { localizada em cavidade } \\
\text { extremamente } \\
\text { contaminada }\end{array}$ & $\begin{array}{l}\text { é rara nesta cirurgia, } \\
\text { mas pode ocorrer } \\
\text { quando a cavidade } \\
\text { (boca) está } \\
\text { contaminada. }\end{array}$ \\
\hline $\begin{array}{l}\text { Você continuará com } \\
\text { aparelho ortodôntico... } \\
\text { por mais algum tempo } \\
\text { (cerca de } 8 \text { meses a } 1 \\
\text { ano) }\end{array}$ & $\begin{array}{l}\text { O tempo de tratamento } \\
\text { ortodôntico no pós- } \\
\text { operatório depende do } \\
\text { ortodontista, portanto o } \\
\text { cirurgião não pode } \\
\text { precisá-lo }\end{array}$ & $\begin{array}{l}\text { Você continuara com } \\
\text { aparelho ortodôntico.... } \\
\text { por mais algum tempo } \\
\text { de acordo com o } \\
\text { ortodontista (cerca de } 8 \\
\text { meses a } 1 \text { ano) }\end{array}$ \\
\hline Retorno após a cirurgia & $\begin{array}{l}\text { Retorno após a cirurgia } \\
\text { trata-se do retorno ao } \\
\text { odontólogo? }\end{array}$ & $\begin{array}{l}\text { Retorno ao consultório } \\
\text { após a cirurgia }\end{array}$ \\
\hline
\end{tabular}


Ao avaliar o quadro percebe-se que as alterações sugeridas resultam de pequenos detalhes que podem melhorar a compreensão do paciente; colocações que o juiz não acreditou estarem claras neste primeiro momento.

As sugestões foram acatadas por serem pertinentes ao conteúdo, e houve maior clareza no item após sua alteração.

A segunda questão que indagava ao juiz se ele tinha sentido falta de alguma informação, trouxe à tona itens relacionados a medicamentos, equipe multiprofissional e algumas sugestões para acréscimo de informações ou revisão de conteúdo.

"informação quanto a medicamentos de uso continuo, medicamentos que podem comprometer o procedimento..."

Entende-se que os medicamentos de uso contínuo devem ser informados ao profissional durante o pré-operatório. Logo, a observação feita pelo juiz foi inserida no trecho "preparo para cirurgia" como um alerta ao paciente da seguinte forma: "lembre-se de avisar ao cirurgião os medicamentos de que faz uso e doenças que possui"

"colocar os profissionais envolvidos no processo: nutricionista, fonoaudiólogo, psicólogo, fisioterapeuta...."

"...Sugiro colocar nas perguntas frequentes "quando poderei voltar a trabalhar após a cirurgia". Sugiro colocar as descrições de técnicas cirúrgicas em uma linguagem mais popular. Sugiro substituir "deformidades faciais" por "deformidades dentofaciais."

A citação dos profissionais da equipe multiprofissional foi realizada no início do material educativo por meio da frase "no pós-operatório os profissionais enfermeiros, nutricionistas, fonoaudiólogos podem estar presentes". A linguagem das descrições cirúrgicas foi melhorada, mas termos técnicos são difíceis de serem alterados para linguagem leiga, o que pode deixar o texto pouco claro. Optou-se então por aguardar a avaliação do paciente. As alterações na nomenclatura "deformidades" foi realizada.

A terceira questão era sobre comentários, deixando o juiz livre para contribuir com sua experiência. A maioria demonstrou satisfação quanto ao material apresentado. 
"o material é muito bom e importante. O apoio escrito auxilia e direciona o paciente, uma vez que a ansiedade impede fixar informações, dúvidas."

"Parabéns pela organização do material e qualidade estética, será de grande ajuda ao paciente e familiares."

"este material possui bom conteúdo, retirando todas as dúvidas necessárias ao publico alvo..."

A satisfação com o primeiro esboço do material educativo dá indícios de que o pesquisador segue no caminho correto e que a pesquisa até o momento atinge seu objetivo. Entretanto, três comentários apresentaram críticas ao material educativo e estão relacionadas a informação alimentar, estética e formato do texto.

"as informações sobre a dieta são especificas para a experiência do serviço para quem esta elaborando o material, porem resultados muito distintos são obtidos quando há o trabalho em equipe.."

Sabe-se que variações de cardápio ou até mesmo de conduta entre os pacientes é pratica comum no período perioperatório, pois cada paciente reage de uma forma. A dieta proposta é um protocolo generalizado, mas alguns pacientes podem não conseguir alcançar o cronograma proposto, seguindo 0 seu próprio planejamento para voltar à dieta normal.

Durante o acompanhamento no pós-operatório, caso o paciente apresente algum distúrbio alimentar ou se sua perda de peso for significativa, é indicada uma consulta com uma nutricionista para um tratamento individualizado.

\footnotetext{
"as imagens não possuem o mesmo traço, uniformidade.."

"diminuir o tamanho e formato do texto"
}

Frente a esses dois comentários, uma nova conversa com os juízes foi realizada para compreender melhor o que significava a frase apresentada. $\mathrm{Na}$ questão das imagens não produzirem o mesmo traço, o juiz se referiu à diferença entre as imagens. Para ele, as imagens devem ter as mesmas cores e traços de desenho, o que para o pesquisador não é interessante e não está dentro da proposta, pois deixaria o trabalho monótono e não despertaria 0 interesse do paciente. 
Sobre diminuir o tamanho e formato do texto, entende-se que uma quantidade grande de informações deve ser passada, e o espaçamento entre linhas deve ser seguido para facilitar a leitura do material. Devido o tamanho pequeno do papel e a necessidade de imagens, o material mais enxuto que compreende 24 páginas, seria o apresentado.

Optou-se por manter este padrão de formatação e reavaliar segundo a perspectiva do paciente, quando submetido à sua avaliação, uma vez que o material está direcionado ao paciente e se este o considerar atrativo o objetivo do pesquisador seria atingido.

Por fim, as alterações julgadas como pertinentes pelo pesquisador foram realizadas e um novo material educativo foi impresso, reenviado aos juízes, juntamente com o questionário aplicado nesta rodada, dando origem à terceira rodada da técnica Delphi.

\subsubsection{TERCEIRA RODADA DA TECNICA DELPHI}

A terceira rodada da técnica Delphi consistiu no envio do material educativo reformulado e seus resultados derivam da leitura e posterior preenchimento do instrumento enviado. O mesmo instrumento enviado na segunda rodada foi aplicado nesta rodada.

Aos 10 juízes que opinaram sobre o material educativo foi dado um prazo de 10 dias para envio da sua avaliação. O prazo estabelecido somente foi cumprido por três juízes. Após 15 dias do envio do material foram recebidos mais dois instrumentos. Com 20 dias foram recebidos dois instrumentos e com 30 dias, três instrumentos.

Os resultados obtidos com o instrumento foram analisados de forma quantitativa, por meio dos itens do instrumento de coleta de dados e mantidos na mesma sequência de grupos de avaliação do instrumento. A tabela 5.9 apresenta a análise dos resultados obtidos com 0 instrumento aplicado aos juízes por níveis de variação da escala Likert. 
Tabela 5.9 - Distribuição da frequência absoluta de escores obtidos por juízes segundo os itens do instrumento na terceira rodada da técnica Delphi. São Paulo. 2011

\begin{tabular}{|c|c|c|c|c|c|c|}
\hline \multirow[b]{2}{*}{ Itens } & \multicolumn{6}{|c|}{ Escores } \\
\hline & $\begin{array}{l}\text { Discordo } \\
\text { totalmente }\end{array}$ & Discordo & $\begin{array}{c}\text { Não } \\
\text { discordo } \\
\text { nem } \\
\text { concordo } \\
\end{array}$ & Concordo & $\begin{array}{l}\text { Concordo } \\
\text { totalmente }\end{array}$ & Amostra \\
\hline \multicolumn{7}{|l|}{ Conteúdo } \\
\hline 1.1 O conteúdo está apropriado ao público alvo & - & - & - & 3 & 7 & 10 \\
\hline 1.2 A divisão dos títulos e subtítulos do material são pertinentes & - & - & - & 2 & 8 & 10 \\
\hline $\begin{array}{l}1.3 \text { Os trechos chave (trechos em destaque) são pontos } \\
\text { importantes e merecem destaque }\end{array}$ & - & - & - & 1 & 9 & 10 \\
\hline $\begin{array}{l}1.4 \text { O conteúdo é suficiente para atender as necessidades do } \\
\text { público alvo }\end{array}$ & - & - & - & 3 & 7 & 10 \\
\hline 1.5 A sequência do texto é lógica & - & - & - & 3 & 7 & 10 \\
\hline Subtotal em porcentagem & - & - & - & $24 \%$ & $76 \%$ & $100 \%$ \\
\hline \multicolumn{7}{|l|}{ Linguagem } \\
\hline 2.1 O estilo da redação é compatível com o público alvo & - & - & - & 5 & 5 & 10 \\
\hline 2.2 A escrita utilizada é atrativa & - & - & 1 & 4 & 5 & 10 \\
\hline 2.3 A linguagem é clara e objetiva & - & - & - & 3 & 7 & 10 \\
\hline Subtotal em porcentagem & - & $=$ & $3,3 \%$ & $40 \%$ & $56,6 \%$ & $100 \%$ \\
\hline \multicolumn{7}{|l|}{ Ilustrações } \\
\hline $\begin{array}{l}\text { 3.1 As ilustrações utilizadas são pertinentes com o conteúdo do } \\
\text { material e elucidam o conteúdo }\end{array}$ & - & - & - & 2 & 8 & 10 \\
\hline $\begin{array}{l}\text { 3.2 As ilustrações são claras e transmitem facilidade de } \\
\text { compreensão }\end{array}$ & - & - & - & 2 & 8 & 10 \\
\hline $\begin{array}{l}\text { 3.3 As legendas aplicadas às imagens estão adequadas e auxiliam } \\
\text { o leitor a compreender a imagem }\end{array}$ & - & - & - & 3 & 7 & 10 \\
\hline $\begin{array}{l}\text { 3.4 A quantidade de ilustrações esta adequada para o conteúdo do } \\
\text { material educativo }\end{array}$ & - & - & - & 3 & 7 & 10 \\
\hline Subtotal em porcentagem & - & - & - & $25 \%$ & $75 \%$ & $100 \%$ \\
\hline
\end{tabular}


Continuação

\begin{tabular}{|c|c|c|c|c|c|c|}
\hline \multirow[b]{2}{*}{ Itens } & \multicolumn{6}{|c|}{ Escores } \\
\hline & $\begin{array}{l}\text { Discordo } \\
\text { totalmente }\end{array}$ & Discordo & $\begin{array}{c}\text { Não } \\
\text { discordo } \\
\text { nem } \\
\text { concordo }\end{array}$ & Concordo & $\begin{array}{l}\text { Concordo } \\
\text { totalmente }\end{array}$ & Amostra \\
\hline \multicolumn{7}{|l|}{ Leiaute } \\
\hline 4.1 O tipo de letra utilizado facilita a leitura & - & - & - & 2 & 8 & 10 \\
\hline 4.3 A composição visual está atrativa e bem organizada & - & - & - & 3 & 7 & 10 \\
\hline $\begin{array}{l}4.4 \text { O formato (tamanho) do material educativo e o número de } \\
\text { páginas está adequado }\end{array}$ & - & - & - & 4 & 6 & 10 \\
\hline 4.5 A disposição do texto está adequada & - & - & - & 5 & 5 & 10 \\
\hline $\begin{array}{l}4.6 \text { O tamanho das letras dos títulos, subtítulos e texto são } \\
\text { adequadas }\end{array}$ & - & - & - & 4 & 6 & 10 \\
\hline Subtotal em porcentagem & $=$ & $=$ & $=$ & $35 \%$ & $65 \%$ & $100 \%$ \\
\hline \multicolumn{7}{|l|}{ Motivação } \\
\hline $\begin{array}{l}5.1 \text { O conteúdo está motivador e incentiva a prosseguir com a } \\
\text { leitura }\end{array}$ & - & - & - & 3 & 7 & 10 \\
\hline 5.2 O conteúdo despertou interesse do leitor & - & - & - & 3 & 7 & 10 \\
\hline $\begin{array}{l}5.3 \text { O conteúdo atende às dúvidas, esclarece e educa o paciente } \\
\text { durante o pós-operatório }\end{array}$ & - & - & - & 3 & 7 & 10 \\
\hline Subtotal em porcentagem & - & - & - & $30 \%$ & $70 \%$ & $100 \%$ \\
\hline \multicolumn{7}{|l|}{ Cultura } \\
\hline $\begin{array}{l}\text { 6.1 O texto está compatível com o público alvo, atendendo aos } \\
\text { diferentes perfis de pacientes (maior ou menor entendimento) }\end{array}$ & - & - & - & 4 & 6 & 10 \\
\hline Subtotal em porcentagem & - & $=$ & $=$ & $40 \%$ & $60 \%$ & $100 \%$ \\
\hline Total (22 itens) & - & - & 1 & 68 & 151 & \\
\hline Total em porcentagem & $0 \%$ & $0 \%$ & $0,5 \%$ & $30,9 \%$ & $68,6 \%$ & \\
\hline
\end{tabular}


Como demonstra a tabela 5.9, os juízes tiveram tendência concordante com o material educativo apresentado. Ao analisar os itens, obtivemos (1) não discorda nem concorda, (68) concorda, (158) concorda totalmente. A discordância não foi encontrada em nenhum dos itens.

Quando comparados os resultados da terceira rodada com os da segunda nota-se que os itens concordo diminuiu de 38,2\% (84) para 30,9\% (68), consequentemente, os itens concordo totalmente resultaram em aumento de $61,3 \%$ (135) para 68,6\% (158), o que representa um resultado positivo para o material reformulado, ou seja, significa que o material melhorou perante as expectativas dos juízes.

Uma análise por categoria demonstra que nos itens que se referem a conteúdo 24\% (12) concordaram e 76\% (38) concordaram totalmente. Quando comparado à segunda rodada houve um aumento de $12 \%$ no nível concorda totalmente, o que demonstra melhor aceitação dos juízes para o conteúdo apresentado após aprimoramento do material.

Com isso, $76 \%$ de concordância é satisfatório para o pesquisador manter o conteúdo do material educativo como está, visando seguir os princípios para construção de material educativo e atender às necessidades do paciente.

Linguagem representou 3,3\% (1) não discordaram nem concordaram, $40 \%$ (12) concordaram e $56,6 \%$ (17) concordaram totalmente. Comparada com a rodada anterior a categoria linguagem apresenta discreta melhora $(6,7 \%)$, e optou-se por aguardar o teste de validação com o paciente.

Em ilustrações, 25\% (10) concordaram e 75\% (30) concordaram totalmente. As opções de respostas resultaram em um aumento de $12,5 \%$ no resultado de concordo totalmente, melhorando a aceitação das ilustrações inseridas no material educativo.

A aceitação dos juízes com margem superior a $70 \%$ confirma que alcançou-se o recomendado pela literatura, uma adequação das imagens e 0 significado destas no esclarecimento do texto, auxiliando o paciente na compreensão do conteúdo. 
Leiaute foi a categoria com maior número de itens e 60 (100\%) de opções de respostas e para esta categoria 35\% (21) concordaram e 65\% (39) concordaram totalmente. Um aumento de $3,3 \%$ quando equiparado à rodada anterior.

O leiaute do material foi adequado para grande parte dos juízes. Apesar de não alcançar $70 \%$ de concordância neste item, os comentários sobre 0 material foram positivos, e o fato para não alcançar a meta se deve ao tamanho do material; como já dito, juízes sugeriram que o número de páginas pode entendiar o paciente e fazê-lo desistir. Mas optou-se por manter o formato de páginas e aguardar parecer do paciente.

$\mathrm{Na}$ motivação, $30 \%$ (9) concordaram e $70 \%$ (21) concordaram totalmente. Um índice alto (70\%) foi alcançado e mantido conforme rodada anterior.

A categoria cultura representa 10 (100\%) opções de resposta e, $40 \%$ (4) concordaram e $60 \%$ (6) concordaram totalmente, diferença de $10 \%$ no concordo totalmente relativo à rodada anterior.

Esta análise por categoria permite avaliar que as alterações realizadas no primeiro esboço do material proporcionaram alterações significativas para aprimoramento do material, segundo perspectiva dos juízes e do pesquisador.

Uma segunda visão dos resultados conquistados pode ser vista em uma análise das variáveis da escala Likert por juiz, em que foi denominado o especialista como $\mathrm{E}$ seguido do número a que este corresponde, e estes dados foram agrupados na tabela a seguir. 


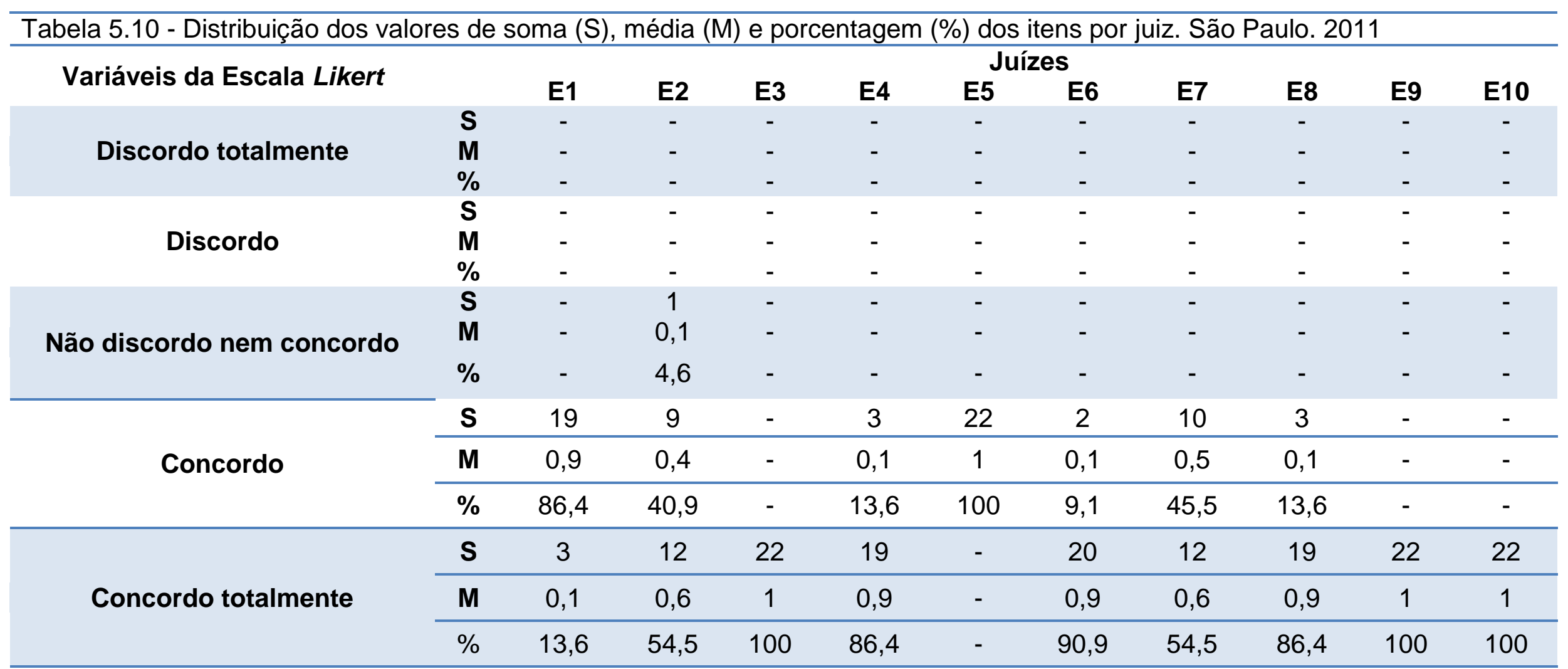


Frente a esses dados e com uma meta de $70 \%$ de itens favoráveis da escala Likert, observou-se que 20\% (2) dos juízes atingiram pontuação acima de $70 \%$ nos itens concordo e 60\% (6) atingiram a mesma pontuação no item concordo totalmente. Os demais $20 \%$ (2) não atingiram, porém mantiveram mais respostas no concordo totalmente.

Quando comparados com a segunda rodada, estes valores expressam aumento nos resultados finais para o nível concordo totalmente da escala Likert. De qualquer forma, representam uma visão global dos níveis da escala Likert determinados por cada juiz.

Nesta rodada, respostas das questões dissertativas relativas a ideias faltantes ou pouco claras foram apresentadas por apenas dois dos juízes e abordaram aspectos relacionados à disposição de legendas, trecho-chave, tempos gramaticais e ortografia.

Quadro 5.10 - Alterações realizadas no material educativo após avaliação dos juízes na terceira rodada da técnica Delphi

\begin{tabular}{|c|c|c|}
\hline Frase original & Sugestão juiz & Alteração realizada \\
\hline Chegou o grande dia & Chegou o dia da cirurgia & Chegou o dia da cirurgia \\
\hline $\begin{array}{l}\text { Você fica com a } \\
\text { cabeceira.... }\end{array}$ & $\begin{array}{l}\text { Você ficará com a } \\
\text { cabeceira.... }\end{array}$ & $\begin{array}{l}\text { Você ficará com a } \\
\text { cabeceira.... }\end{array}$ \\
\hline $\begin{array}{lll}. . . d a \quad \text { cirurgia } & \text { e } & \text { da } \\
\text { sensibilidade } & & \text { da } \\
\text { região... } & & \end{array}$ & $\begin{array}{lr}\text {...da cirurgia e da } \\
\text { mobilidade } \\
\text { sensibilidade da região... }\end{array}$ & $\begin{array}{lr}\text {...da cirurgia e da } \\
\text { mobilidade } \\
\text { sensibilidade da região... }\end{array}$ \\
\hline $\begin{array}{l}\text { Cavidade oral (boca) } \\
\text { está contaminada }\end{array}$ & $\begin{array}{l}\text {...cavidade oral (boca) é } \\
\text { contaminada.. }\end{array}$ & $\begin{array}{l}\text {...cavidade oral (boca) é } \\
\text { contaminada... }\end{array}$ \\
\hline
\end{tabular}

Algumas sugestões foram propostas pelos juízes, tais como:

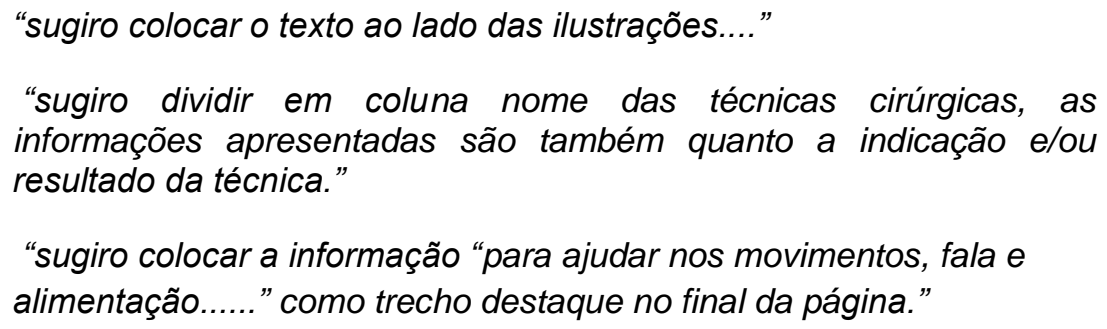

As sugestões apresentadas pelos juízes foram vistas como melhorias e acatadas pelo pesquisador. Os demais juízes mantiveram em branco a área 
destinada a perguntas abertas no impresso, entendendo-se que não encontraram ideias no material que necessitassem de correção.

Os comentários apresentados por apenas cinco juízes trouxeram agradecimentos e parabenizações pelo trabalho. Os demais juízes não expuseram nenhuma resposta neste item.

\begin{abstract}
"trabalho de grande importância que muito facilitará o processo de orientação ao paciente e a família nos casos de cirurgia ortognática. Agradeço a oportunidade de contribuir"

"o material esta claro, objetivo e didático"

"excelente manual, ótima proposição, elucidativo"

"muito bom, excelente"

"agradeço ter inserido a informação sobre a posição da lingua e o uso da mesma para propriocepção intraoral. O trabalho fonoaudiólogo é muito importante para a reorganização funcional pós-cirurgica. Parabenizo a iniciativa e o trabalho, pois os pacientes não guardam todas as informações verbalizadas, especialmente devido à ansiedade. O material reduz a ansiedade e também conforta o paciente quanto ao que se pode experenciar".
\end{abstract}

É gratificante ao pesquisador colher bons frutos de sua pesquisa, ver que o material construído atinge as expectativas de outros profissionais e que é visto como método de contribuição nas orientações verbais. Isso demonstra o alcance do objetivo desta pesquisa.

Entende-se que estas alterações não interferem no conteúdo do material e não possuem impacto no leiaute. Com isso a rodada de avaliação proposta pela técnica Delphi se encerra aqui, dando seguimento a validação de clareza da leitura pelos pacientes.

Com as alterações, um novo material educativo foi impresso para o próximo passo desta trajetória metodológica.

\title{
5.6 QUINTA FASE - APLICAÇÃO DO MATERIAL EDUCATIVO AOS PACIENTES
}

Validado o material educativo pelos juízes, uma validação por parte dos pacientes para compreensão do texto foi realizada. 


\subsubsection{MATERIAL E MÉTODO}

Uma vez validado o constructo pelos juízes, o material educativo foi reimpresso com o mesmo material gráfico, para dar sequência à próxima fase (avaliação dos pacientes).

O material educativo elaborado foi submetido à avaliação dos pacientes com relação à clareza das informações/ilustrações e adequação do conteúdo para apoio no pós-operatório. Juntamente com o material, uma carta de apresentação, um questionário de caracterização do paciente e o termo de consentimento livre e esclarecido foi enviado.

Os pacientes que participaram desta fase do projeto foram aqueles submetidos à cirurgia ortognática em acompanhamento no consultório de cirurgia e traumatologia bucomaxilofacial. A amostra foi constituída por 20 pacientes. Este tamanho amostral foi determinado baseado na condição de um número restrito de cirurgias realizadas por mês (2 a 3), que, ao longo de um ano, período para conclusão desta pesquisa, proporciona 24 pacientes. Levando em consideração a possibilidade de desistência de alguns pacientes, optou-se pela amostra de 20 pacientes. Estes pacientes foram oriundos do consultório de cirurgia e traumatologia bucomaxilofacial, podendo ter sido operados em hospital público ou privado.

Para avaliação dos pacientes quanto ao material educativo, optou-se pela aplicação de um instrumento adaptado da dissertação de mestrado intitulada "Autocuidado da mulher na reabilitação da mastectomia: estudo de validação de aparência e conteúdo de uma tecnologia educativa" (Apêndice I). Nessa pesquisa o instrumento foi construído e validado baseado na adaptação da teoria de Pasquali, que envolve a elaboração de instrumentos de medida de fenômenos subjetivos, composta por três conjuntos de procedimento: teóricos, empíricos e analíticos ${ }^{124}$.

Além da teoria de Pasquali, a pesquisadora aplicou na construção do questionário uma adaptação de um instrumento americano denominado Suitability Assessment of Materials (SAM), usado para avaliar adequação de material educativo, desenvolvido em 1993 e validado com 172 profissionais de 
saúde de vários países e culturas diferentes e alunos da University of North Carolina School of Public Health and Johns Hopkins School of Medicine. O instrumento americano consiste em um check-list com seis categorias (conteúdo, compreensão do texto, ilustração, apresentação, motivação e adaptação cultural). Aplicado após a leitura do texto, o resultado da somatória dos pontos atribuídos a cada item do instrumento categoriza o material quanto à adequação para pacientes ${ }^{97}$.

Para aplicar o instrumento criado por essa pesquisadora no presente estudo foi necessário realizar uma adaptação nos itens do instrumento que se referiam à mulher mastectomizada para o paciente submetido a cirurgia ortognática, assim como, uma alteração nos níveis da escala Likert de totalmente adequado, parcialmente adequado, adequado e inadequado para discordo totalmente, discordo, não discordo nem concordo, concordo e concordo totalmente.

Juntamente ao instrumento de avaliação do material educativo foi aplicado um outro instrumento para coletar informações socioculturais e da cirurgia do paciente (Apêndice $G$ )

Após a finalização deste processo o material foi confeccionado em gráfica com papel couché $150 \mathrm{~g}$ e a capa em couché $230 \mathrm{~g}$ com impressão em cores.

\subsubsection{RESULTADOS}

\subsubsection{CARACTERIZAÇÃO DOS PACIENTES}

O instrumento aplicado juntamente ao instrumento de validação para o material educativo perante os pacientes permitiu definir a caracterização destes pacientes.

As características relacionadas a sexo, idade, ocupação profissional, estado civil, escolaridade e tempo de preparo cirúrgico são demonstradas no quadro (5.11). 
Quadro 5.11 - Características socioculturais. Tempo de preparo cirúrgico dos pacientes que validaram o material educativo para cirurgia ortognática. São Paulo. 2011

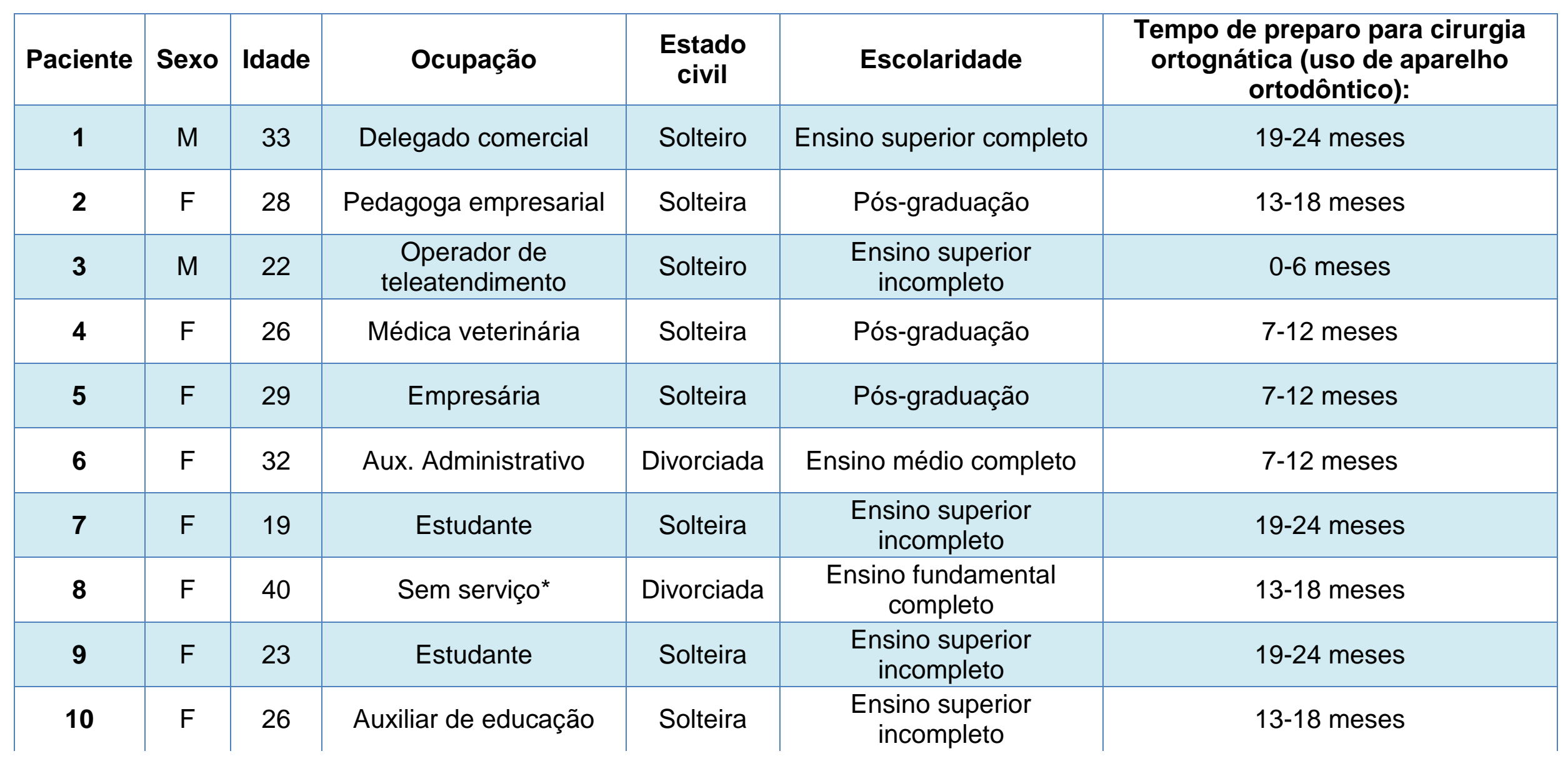


Continuação

\begin{tabular}{|c|c|c|c|c|c|c|}
\hline Paciente & Sexo & Idade & Ocupação & $\begin{array}{l}\text { Estado } \\
\text { civil }\end{array}$ & Escolaridade & $\begin{array}{c}\text { Tempo de preparo para cirurgia } \\
\text { ortognática (uso de aparelho } \\
\text { ortodôntico): }\end{array}$ \\
\hline 11 & M & 35 & $\begin{array}{l}\text { Operador de } \\
\text { computador jr }\end{array}$ & Casado & Ensino médio completo & $19-24$ meses \\
\hline 12 & M & 47 & Artista plástico & Solteiro & Ensino superior completo & $0-6$ meses \\
\hline 13 & $\mathrm{~F}$ & 41 & Encarregada $\mathrm{RH}$ & Casada & Ensino superior completo & 19-24 meses \\
\hline 15 & $\mathrm{~F}$ & 33 & $\begin{array}{c}\text { Analista de contas a } \\
\text { receber }\end{array}$ & Casada & Pós-graduação & 7-12 meses \\
\hline 16 & M & 34 & Analista de sistema & Casado & Pós-graduação & 13-18 meses \\
\hline 17 & $\mathrm{~F}$ & 40 & $\begin{array}{l}\text { Coordenadora } \\
\text { pedagógica }\end{array}$ & Solteira & Pós-graduação & $19-24$ meses \\
\hline 19 & $\mathrm{~F}$ & 42 & Estudante & Divorciada & Ensino superior completo & 7-12 meses \\
\hline 20 & $M$ & 52 & Empresário & Casado & Ensino superior completo & $13-18$ meses \\
\hline
\end{tabular}

*Segundo informação do paciente 
Ocorreu uma predominância do sexo feminino $65,0 \%$ (13) frente ao masculino 35,0\% (7). A idade média é de 32,5 anos; destes, onze disseram ser solteiros, seis casados e três divorciados.

O tempo de preparo para a cirurgia foi de $19-24$ meses para $40,0 \%$ (8) dos pacientes, seguido de 13-18 meses $(n=5 ; 25,0 \%), 7-12$ meses $(n=5$; $25,0 \%$ ) e $0-6$ meses $(n=2 ; 10,0 \%)$. Os resultados mostram o tempo longo do tratamento ortognático, assim como descrito em literatura.

$\mathrm{Na}$ análise da escolaridade, obtiveram-se 30,0\% (6) dos pacientes com pós-graduação, $25,0 \%$ (5) com superior completo, 20,0\% (4) com nível superior incompleto, $20,0 \%$ (4) com ensino médio e $5,0 \%$ (1) ensino fundamental.

Apesar do nível elevado de escolaridade desta amostra de pacientes, a compreensão de informação médica pode ser deficiente, mesmo para este perfil de paciente, não excluindo a necessidade de informação médica por escrito e com texto compreensível para níveis de menores escolaridade.

\subsubsection{ANÁLISE DE COMPREENSÃO DOS PACIENTES}

Um instrumento adaptado com 26 itens e cinco níveis de escala Likert (discordo totalmente, discordo, não discordo nem concordo, concordo e concordo totalmente) foi aplicado aos pacientes para analisar a compreensão sobre o material educativo. Os resultados deste instrumento são demonstrados na tabela 5.11 . 
Tabela 5. 11 - Distribuição da frequência absoluta de escores obtidos por pacientes segundo os itens do instrumento de avaliação do material educativo. São Paulo. 2011.

\begin{tabular}{|c|c|c|c|c|c|c|}
\hline \multirow[b]{2}{*}{ Itens } & \multicolumn{6}{|c|}{ Escores } \\
\hline & $\begin{array}{l}\text { Discordo } \\
\text { totalmente }\end{array}$ & Discordo & $\begin{array}{c}\text { Não } \\
\text { concordo } \\
\text { nem } \\
\text { discordo }\end{array}$ & Concordo & $\begin{array}{l}\text { Concordo } \\
\text { totalmente }\end{array}$ & Amostra \\
\hline \multicolumn{7}{|l|}{ 1.Objetivos } \\
\hline $\begin{array}{l}\text { 1.1 Atende aos objetivos dos pacientes que fizeram a cirurgia ortognática e } \\
\text { estão em processo pós-operatório }\end{array}$ & - & - & 1 & 8 & 11 & 20 \\
\hline 1.2 Ajuda durante o processo de pós-operatório & - & - & 1 & 8 & 11 & 20 \\
\hline $\begin{array}{l}\text { 1.3 Está adequado para ser usado por qualquer profissional envolvido no } \\
\text { processo da cirurgia }\end{array}$ & - & - & 2 & 7 & 11 & 20 \\
\hline Subtotal em porcentagem & $=$ & - & $6,6 \%$ & $38,3 \%$ & $55 \%$ & \\
\hline \multicolumn{7}{|l|}{ 2. Organização } \\
\hline 2.1 A capa está atraente; indica o conteúdo do material & - & 2 & 1 & 8 & 9 & 20 \\
\hline $\begin{array}{l}\text { 2.2 O tamanho do título da capa e dos subtítulos dentro do material estão } \\
\text { adequados }\end{array}$ & - & 2 & 2 & 6 & 10 & 20 \\
\hline 2.3 Os tópicos seguem uma ordem & - & - & 2 & 6 & 12 & 20 \\
\hline 2.4 Há coerência entre as informações da capa, apresentação e sumário. & - & - & 2 & 6 & 12 & 20 \\
\hline 2.50 material (papel, impressão) está adequado & - & - & 1 & 7 & 12 & 20 \\
\hline 2.6 O número de páginas esta adequado & - & - & 3 & 5 & 13 & 20 \\
\hline 2.7 Os temas retratam aspectos chave importantes & - & - & 1 & 6 & 13 & 20 \\
\hline Subtotal em porcentagem & - & $2,8 \%$ & $7,8 \%$ & $31,4 \%$ & $57,8 \%$ & \\
\hline \multicolumn{7}{|l|}{ 3. Estilo da escrita } \\
\hline 3.1 A escrita está em um estilo adequado ao paciente & - & - & 2 & 4 & 14 & 20 \\
\hline 3.2 O texto é vívido e interessante. O tom é amigável & - & - & 1 & 4 & 15 & 20 \\
\hline 3.3 O vocabulário é acessível & - & - & - & 5 & 15 & 20 \\
\hline 3.4 Há associação do tema de cada sessão com o texto correspondente & - & 1 & - & 5 & 13 & 20 \\
\hline $3.5 \mathrm{O}$ texto está claro & - & - & 2 & 5 & 13 & 20 \\
\hline Subtotal em porcentagem & $=$ & $0,8 \%$ & $4,1 \%$ & $25,8 \%$ & $68,3 \%$ & \\
\hline
\end{tabular}


Continuação

\begin{tabular}{|c|c|c|c|c|c|c|}
\hline \multirow[b]{2}{*}{ Itens } & \multicolumn{6}{|c|}{ Escores } \\
\hline & $\begin{array}{l}\text { Discordo } \\
\text { totalmente }\end{array}$ & Discordo & $\begin{array}{c}\text { Não } \\
\text { concordo } \\
\text { nem } \\
\text { discordo }\end{array}$ & Concordo & $\begin{array}{l}\text { Concordo } \\
\text { totalmente }\end{array}$ & Amostra \\
\hline \multicolumn{7}{|l|}{ 4. Aparência } \\
\hline 4.1 As páginas ou sessões parecem organizadas & - & - & 1 & 7 & 12 & 20 \\
\hline 4.2 As ilustrações são simples & - & - & - & 8 & 12 & 20 \\
\hline 4.3 As ilustrações servem para complementar os textos & - & 1 & 1 & 6 & 12 & 20 \\
\hline 4.4 As ilustrações são expressivas e suficientes & - & - & 1 & 8 & 11 & 20 \\
\hline Subtotal em porcentagem & $=$ & $1,2 \%$ & $3,7 \%$ & $36,2 \%$ & $58,7 \%$ & \\
\hline \multicolumn{7}{|l|}{ 5. Motivação } \\
\hline 5.1 O material está apropriado para idade, gênero e cultura & - & 2 & - & 8 & 10 & 20 \\
\hline 5.2 O material apresenta lógica & - & - & - & 9 & 11 & 20 \\
\hline 5.3 A interação é convidada pelo texto. Sugere ações & - & - & - & 9 & 11 & 20 \\
\hline $\begin{array}{l}5.4 \text { O material aborda assuntos necessários ao paciente que faz a cirurgia } \\
\text { ortognática }\end{array}$ & - & - & - & 6 & 14 & 20 \\
\hline 5.5 Promove mudança de comportamento e atitude & - & - & 2 & 9 & 9 & 20 \\
\hline 5.6 O material propõe ao paciente conhecimento para realizar o autocuidado & - & - & - & 8 & 12 & 20 \\
\hline Subtotal em porcentagem & - & $1,6 \%$ & $1,6 \%$ & $40,8 \%$ & $55,8 \%$ & \\
\hline Total (26 itens) & - & 8 & 25 & 176 & 310 & 520 \\
\hline Total em porcentagem & - & $1,5 \%$ & $4,8 \%$ & $33,8 \%$ & $59,6 \%$ & $100 \%$ \\
\hline
\end{tabular}


Como demonstra a tabela 5.11, os pacientes tiveram tendência concordante com o material educativo apresentado. Ao analisar os itens obtivemos discorda (8), não discorda nem concorda (25), concorda (176), concorda totalmente (310). Não houve nenhum discordo totalmente.

Uma análise por categoria demonstra que, nos itens que se referem a objetivos, 6,6\% (4) não concordaram nem discordaram, 38,3\% (23) concordaram e 55\% (33) concordaram totalmente. Os resultados demonstram resultado positivo com o objetivo proposto pelo material, visto pela concordância da maioria dos pacientes.

No item organização 2,8\% (4) discordam, 7,8\% (11) não concordam nem discordam, 31,4\% (44) concordam e 57,8\% (81) concordam totalmente. A organização do material foi bem aceita pelos pacientes. Uma porcentagem pequena da amostra discordou da organização, o que demonstra discordância no item relacionado a capa e título do material; apenas um paciente comentou o tópico sobre o assunto.

Para estilo da escrita 0,8\% (1) discordam, 4,1\% (5) não concordam nem discordam, 25,8\% (31) concordam e 68,3\% (82) concordam totalmente. Pode-se dizer que a escrita foi compreendida pelos pacientes, visto que a maioria dos pacientes concorda totalmente com o estilo da escrita.

Em aparência 1,2\% (1) discordam, 3,7\% (3) não concordam nem discordam, 36,2\% (29) concordam e 58,7\% (47) concordam totalmente. A aparência geral do material foi aceita pelos pacientes, predominando a concordância total dos pacientes.

Quanto à motivação 1,6\% (2) discordam, 1,6\% (2) não discordam nem concordam, 40,8\% (49) concordam e 55,8\% (67) concordam totalmente. $O$ fato de a maioria dos pacientes demonstrarem concordância total nos itens relacionados, a motivação demonstra que os pacientes sentiram-se motivados com o material educativo.

Após a escala Likert, o instrumento apresentava uma questão aberta que sugeria comentários ou sugestões do paciente para o material 
educativo, e notou-se uma satisfação dos pacientes com o material apresentado.

\begin{abstract}
"Parabéns pelo seu trabalho!!!! Quando fiz a minha cirurgia havia pouca informação. O seu trabalho de Mestrado vai ajudar muito todas as pessoas que pretendem fazer a cirurgia ortognática".[R1]

"Parabéns, seu trabalho está muito bom, pode ajudar muita gente".[R6]

"Penso que a própria existência de um material educativo já é um avanço..."[R7]

"O material ficou excelente!... e esse material sanou todas as dúvidas que ainda restaram. Além de ter ficado bem completo, ficou com uma linguagem compreensível e super adequada.[R14]
\end{abstract}

Apenas um dos pacientes comentou sobre a capa do material. Esta pode ser a mesma ideia dos demais que opinaram pela não concordância com este item.

"Para a capa dar um aspecto mais amigável, menos cadavérico na ilustração, para não criar uma relação de risco de morte com a cirurgia ortognática”. [R20]

Entretanto, a imagem da capa é semelhante a um cartoon do desenho anatômico do crânio, com as placas de fixação.

Outros pacientes fizeram comentários relacionados à importância do tratamento ou à falta de informação e não diretamente ao material educativo.

"Esta é uma cirurgia muito séria pois envolve o psicológico, e por este motivo precisamos de profissionais da área bem como fonoaudiólogo atuando juntamente com o buco e com o orto. Mexe com a estima com um sonho e com a saúde. Hoje você se olha no espelho, amanhã não se reconhece mais..." [R2]

"A única reclamação ... foi a carência de um psicólogo integrandoa, para acompanhar gente como eu, que sou pouco claustrofóbica e tive que me segurar por causa dos dentes amarrados, e outros pacientes com ideias de que todos os problemas da vida acabarão após a cirurgia".[R9]

"Esta cirurgia é muito importante para quem sofre com essas deformidades faciais...Falta divulgação".[R12]

Alguns pacientes fizeram a avaliação do material baseada em sua vivência de pós-operatório e não uma avaliação sobre a compreensão do material. 
"Apesar de entender que o conteúdo deve ser mais geral, sugiro que seja expressado que muitas coisas do P.O podem variar, por exemplo, o no meu caso não foi feito uso de pino algum..."[R10]

"Aqui vão algumas sugestões: Tive sangramento pelo nariz também. No meu caso colocaram uma placa de acrílico no céu da boca, que ficou por 15 dias era muito incomoda. Quando voltei para o quarto e senti um mal estar muito grande, falta de ar e ânsia de vomito, só melhorou após vomitar o sangue que acumulou no meu estomago"[R14]

De forma geral o material atendeu às dúvidas do paciente. Por falta de comentários sobre os tópicos que não atenderam à concordância do paciente nenhuma alteração pode ser realizada no material.

Fica claro que a compreensão do texto do material foi alcançada e este era o objetivo da avaliação do paciente sobre o material.

Finalizado a construção do material educativo foi solicitado à Fundação da Biblioteca Nacional o cadastramento do pesquisador e o código ISBN para o material educativo, bem como, o registro dos direitos autorais sobre a obra. 


\section{DISCUSSÃO}

Normalmente, a criação de um material educativo requer dois tipos de pesquisa: uma de tipo temático e outra de tipo diagnóstico, em que será preciso ler o que alguns autores disseram sobre o tema, conhecer a opinião de alguns peritos, ou incorporar alguns destes peritos na equipe de produção. Depois disso, será preciso escolher as ideias centrais que serão abordadas pelo material, bem como o tema por meio do qual se procurará gerar uma experiência de aprendizado. No entanto, a opinião de peritos ou a leitura de textos não bastará. Devemos conhecer também os contextos pedagógicos e, principalmente os sujeitos aos quais está destinado o material $^{125 .}$

Baseado nesta premissa, o material educativo para pacientes submetidos à cirurgia ortognática contou com a participação de peritos com múltiplo conhecimento (equipe multiprofissional) e de pacientes na busca de conhecer suas necessidades. Devido à evolução da vida virtual, a internet também foi inserida neste contexto e pacientes virtuais também foram levados em consideração, assim como suas necessidades, com a utilização de pesquisa em comunidades virtuais.

Essas diversas fontes de informação trouxeram para o material educativo contribuições sobre o conteúdo, formato, momento de entrega, dificuldades vivenciadas e necessidades de conhecimento.

Os juízes contribuíram com informações relevantes relacionadas a orientações em fase pré-operatória, intraoperatória e pós-operatória. As mais citadas foram: higiene oral, parestesia, edema facial, dificuldade mastigatória e respiratória, alteração da voz e movimentos musculares pós-operatórios e dieta.

Para os pacientes, as informações consideradas importantes abrangem as dificuldades vivenciadas (dor, alimentação, parestesia, 
anestesia, medos do procedimento, como é a recuperação, cuidados com sutura, repouso e estética facial após procedimento).

Este tipo de construção do conteúdo, baseado no conhecimento de profissionais e público alvo, foi aplicado em outros estudos. No material educativo para mães de prematuros, a participação de profissionais e das mães definiu os cinco temas importantes para aprender e ensinar que deveriam estar no material educativo: cuidados especiais, higiene, cuidados diários, alimentação e relacionamento familiar ${ }^{126 .}$

Em um material educativo para mulheres mastectomizadas, a equipe multiprofissional considerou importante a caracterização do sistema linfático e do linfedema, as ações de detecção e controle, seus fatores de risco, incluindo-se as próprias terapias para o câncer de mama e suas repercussões sobre o organismo. Para as mulheres, era importante um esclarecimento sobre todo o processo fisiopatológico do linfedema, o conhecimento da cirurgia, tratamentos adjuvantes e suas consequências e os fatores físicos, emocionais e sociais que predispõem ao linfedema ${ }^{81}$.

Para os pacientes renais, seria fundamental conter informações sobre alimentação, significado dos resultados de exames, tratamento dialítico, transplante renal, sexualidade e relacionamento interpessoal. Esse estudo não levou em consideração os profissionais envolvidos no cuidado destes pacientes $^{127 .}$

Seguindo a mesma linha de trabalhar somente com informações de pacientes, outro estudo construiu um material educativo sobre alimentação saudável para adolescentes, e por eles foram levantados os seguintes pontos importantes: informar os alimentos que podem substituir alimentos não saudáveis, mensagens alarmantes sobre os riscos de saúde pela alimentação inadequada, informações lúdicas, como histórias em quadrinhos e jogos de estratégia ${ }^{128}$.

As manifestações dos sujeitos servem, portanto, para subsidiar a elaboração do material didático a ser utilizado na prática educativa, pois 
retratam necessidades percebidas pelos participantes que têm a experiência vivenciada $^{127 .}$

Por outro lado, a visão dos juízes também é importante, pois os pacientes tomam como base suas dificuldades individuais e alguma informação importante poderia ser omitida.

Em um estudo que avalia os impressos hospitalares sob a ótica do profissional, foi evidenciado que a produção de materiais educativos são atreladas à experiência do atendimento médico, o que faz com que contemplem apenas algumas dúvidas e questionamentos mais comuns da clientela sobre os problemas específicos abordados nos materiais. No entanto, esse procedimento resulta em simplificações, generalizações e reducionismos relacionados ao que "o paciente quer" ${ }^{129}$.

Por isso, é fundamental ouvir a necessidade de conhecimento do público-alvo e suprir esta necessidade com informações baseadas no conhecimento científico e dos profissionais que o atendem.

Construir um material educativo implica realizar um trabalho de préalimentação da mensagem educativa a elaborar, saber o que sabem, o que querem, o que pensam, imaginam, ignoram do tema em questão, e a quais necessidades o material poderia responder. Isso será decisivo para construir o eixo pedagógico ${ }^{125}$.

Outras características levantadas pelos pacientes são percebidas no desejo de todos os participantes de obter o material escrito em formato livreto ou cartilha, com texto, figuras e colorido; há expectativa de que o material permaneça com o paciente para ser consultado em domicilio e suprir as dúvidas ${ }^{126-128,130}$. Esses aspectos também foram observados nesta pesquisa.

Assim, pode-se dizer que o público alvo contribui para a construção do conteúdo e o leiaute do material, tornando-o mais direcionado a eles e consequentemente mais atrativo e motivador. 
Estudos na área de educação provocam o aumento do envolvimento do paciente na decisão da cirurgia por meio do cuidado focado no paciente e usando materiais educativos de qualidade para melhorar a comunicação entre o cirurgião e o paciente ${ }^{131}$.

Como demonstrado nesta pesquisa, alguns tópicos são essenciais para a construção de um material educativo, como: conteúdo, linguagem, ilustrações, motivação e adequação cultural.

Os conteúdos organizados e transformados em mensagens precisam ter o discurso direto, de modo a possibilitar um intercâmbio de comunicação efetiva, para que o leitor compreenda a mensagem, favorecendo a identificação e a formação de um vínculo ${ }^{132}$

É como fazer o leitor/paciente sentir-se parte do texto, reconhecendose e motivando-se a continuar a leitura, o que melhora sua adesão ao material educativo.

Para os pacientes ortognáticos, o conteúdo foi construído baseado na necessidade do paciente e no que o profissional acreditava ser importante na orientação desse paciente. Tendo os tópicos do conteúdo, o texto discorreu sobre o conhecimento científico traduzido e adequado à linguagem deste paciente.

A linguagem é geralmente referida como um conjunto de palavras "fáceis e difíceis", uma vez que todos compartilham a crença de que adequar a linguagem é traduzir termos técnicos utilizados em textos científicos, para explicar as doenças em termos acessíveis aos usuários ${ }^{129}$.

A linguagem e a lógica do material estão entre as incompatibilidades da relação cirurgião-paciente. Seja pelo nível de literância do paciente (que não pode compreender as informações escritas) ou pelo conteúdo não atender as expectativas do leitor ${ }^{133}$.

Por outro lado, vale lembrar que a educação do paciente para ser eficaz deve ser uma combinação de orientação verbal do profissional e do 
uso de uma ferramenta de apoio para reforçar as orientações, sejam estas, um vídeo, um folheto, um livreto ou material de áudio. Deve haver um método adequado a cada perfil de paciente.

Embora alguns juízes tenham manifestado a preferência por um traço comum de desenho, na literatura não se afirma que as imagens devam seguir sempre o mesmo padrão de desenho para melhor resultado deste material. Em outros materiais educativos, nota-se que imagens de diferentes perfis destacam-se, chamando a atenção, em contrapartida para as ilustrações que mantém mesmo traço tornam-se iguais após duas a três folheadas no material e não atraem o leitor para o conteúdo.

llustrações criadas por cartunista foram adotadas neste material educativo para adequar a imagem ao conteúdo e elucidar o paciente frente o texto. Técnicas cirúrgicas não poderiam ser renomeadas e imagens de livros de anatomia não agradariam o paciente, logo, desenhos foram criados para fazer a conexão com o texto.

Como era desejo do paciente saber como ficariam as imagens do material para fixação, imagens de tomografia foram reproduzidas em desenho para suprir a necessidade deste público. Para elucidar os exercícios do pós-operatório, imagens faciais foram criadas.

Alguns estudos apenas afirmam que os trabalhos que aplicam desenhos simples são mais eficazes no sentido de facilitar a compreensão ${ }^{134,135 .}$ A vantagem de desenhos simples sobre imagens mais complexas pode estar relacionada à distração advinda do excesso de detalhes ${ }^{79}$.

A ilustração com cartoons é uma estratégia efetiva para assimilar 0 texto e prover a compreensão do paciente com as instruções fornecidas ${ }^{96}$.

O leiaute tem uma influência substancial sobre adesão do material. Sequência de conteúdo, organização de ideias, destaques dos trechos importantes, uso de cores, espaçamento, papel de qualidade e tipo de letra pode facilitar a leitura do material educativo ${ }^{136}$. 
Um leiaute prévio do material educativo foi criado após a junção de todas as informações sobre impressões gráficas e designs de materiais buscadas pelo pesquisador na literatura. Esse esboço foi revisto pelo pesquisador, orientador, com o conselho de um profissional de comunicação e avaliação dos juízes e pacientes, sendo alterado durante o processo de construção do material educativo a fim de alcançar o objetivo previsto.

Um conjunto de itens (conteúdo adequado, leiaute atrativo, imagens claras, linguagem acessível, adequação à cultura do público-alvo) desenvolverá a motivação do paciente em prosseguir com a leitura e aderir ao autocuidado com o uso de material educativo ${ }^{136}$. A motivação por parte dos juízes já alcançou a meta de $70,0 \%$ no primeiro esboço, afirmando ser benéfico o uso deste material a este perfil de paciente.

A adequação cultural fará com que o leitor se identifique com o material, uma vez que este se identifica com suas crenças e valores e está voltado para sua vivência.

Este processo de construção que permite exclusão, inclusão e / ou modificação de informações educacionais com base em uma variedade de critérios, incluindo procedimento cirúrgico, complicações, terapias adjuvantes e qualquer outro fator considerado importante, embora não possa substituir o diálogo cirurgião-paciente com o qual é obtido o consentimento informado, é bem aceito pelos pacientes, pois uma pequena fração das informações comunicadas neste diálogo é realmente retida pelo paciente ${ }^{131}$

O processo de validação foi visto de forma semelhante em diferentes estudos de materiais educativos ${ }^{124,126,137}$, com avaliação de profissionais e pacientes. Entretanto, a concordância destes não foi muito discutida.

A concordância dos profissionais com o material educativo nesta pesquisa apresentou resultados crescentes entre a segunda e terceira fase da técnica Delphi. Os itens da escala Likert, concordo e concordo totalmente, apresentaram respectivamente $30,9 \%$ e $68,6 \%$ na terceira rodada. Estes valores não foram somados como em outro estudo de construção de material educativo para mulheres mastectomizadas, que 
considerou concordo e concordo totalmente como itens positivos e semelhantes, podendo seus resultados serem somados. Entretanto, se nesta pesquisa os resultados fossem somados representariam $99,5 \%$ de concordância.

A linguagem, uma das dimensões de avaliação para os juízes, foi a que apresentou menor pontuação em relação às demais. No entanto, segundo a avaliação dos pacientes, a escrita foi a dimensão de seu instrumento de avaliação com melhor pontuação, o que mostra que a compreensão da linguagem adotada está acessível ao público alvo.

No estudo das mulheres mastectomizadas, a concordância foi de $88,5 \%$ para objetividade, $81,0 \%$ para estrutura e apresentação e $91,4 \%$ para relevância ${ }^{124}$.

Outro estudo teve como objetivo avaliar materiais sobre alimentação da criança de 0 a 12 meses de idade, utilizados no programa de Assistência à Criança da Secretaria de Saúde, com o objetivo de fornecer subsídios para reformulação deste material. Neste estudo foi visto pelas mães a "boa compreensão" com variação de $80,0 \%$ a $96,0 \%$ e para o pessoal auxiliar de $90,9 \%$ a $100,0 \%{ }^{138}$.

No material educativo desenvolvido para gestantes não ocorreu avaliação de concordância, apenas uma análise qualitativa dos peritos, afirmando que a apresentação do material foi vista como boa, a arte final, excelente, a linguagem de fácil compreensão interessante para as gestantes. Para as gestantes, o material despertou interesse, o conteúdo foi considerado de fácil entendimento ${ }^{137}$.

O material desenvolvido para mães de prematuros, um instrumento aplicado para a enfermagem (peritos deste trabalho), durante o processo de validação apresentou concordância de todos os atributos apresentados para avaliação $^{126}$. No material sobre teste de Papanicolau somente a avaliação das pacientes foi aplicada e obteve $93,0 \%$ de aceitação da capa e 100,0\% de compreensão do material ${ }^{139}$. 
No presente estudo, chamou a atenção um comentário feito sobre a capa. Embora apresentado por apenas um paciente, a mesma foi apontada como "cadavérica", requerendo uma reavaliação dos autores neste quesito quanto à necessidade de maior leveza nos elementos ilustrativos da capa.

Durante o processo de construção e validação do material educativo para pacientes submetidos a cirurgia ortognática, as dificuldades encontradas ocorreram com a composição dos grupos, pois o pesquisador gostaria de poder contar com maior números de pacientes, para ampliar o conhecimento da população, mas isso não foi possível por ausência destes nos encontros marcados.

Deslocar-se para um lugar para contribuir com pesquisa talvez não seja pratica frequente dos brasileiros. Entretanto, o número reduzido de participantes também foi visto em outros estudos: a construção de material para mães de prematuros contou com quatro mães, o material para pacientes renais tinha seis pacientes ${ }^{126,127}$.

Para avaliação do material, cada estudo ${ }^{124,137,139}$ apresentou um instrumento diferente, não havendo uma padronização do instrumento, o que pode ser justificada pela ausência de um instrumento para avaliação de adequação de material educativo em português. Em outros estudos ${ }^{127,130}$, nota-se o uso do método de grupo focal para análise qualitativa do material educativo pelos pacientes.

Mesmo sem padronização para avaliação de adequação de materiais educativos e método para validação destes, é sabido que a construção de materiais educativos voltados para o público alvo, com participação de peritos, pode elevar a aceitação e adesão dos pacientes na utilização deste método de orientação e educação em saúde.

A validação do paciente quanto à compreensão do material educativo construído apresentou concordância de 33,8\% e concordo totalmente de $59,6 \%$. Se somadas representam $93,4 \%$. O item não concordo nem discordo podem estar relacionados à ausência de reconhecimento do paciente com a vivência que ele obteve em seu pós-operatório. 
Notou-se que alguns pacientes fizeram a leitura do material e na avaliação um comparativo a sua vivência, embora não fosse este o objetivo do material. O objetivo desta avaliação era a compreensão das informações realizadas.

Convém afirmar que o material não deve ser apenas entregue ao paciente e, sim, ser um complemento das orientações verbais ao paciente, sendo o material educativo um suporte de informação. O material serve para complementar o processo educativo que começa na primeira consulta.

No estudo realizado em Ribeirão Preto para o desenvolvimento de um material educativo para treinamento das mães, visando alta hospitalar do filho prematuro, a enfermagem concorda que 0 material permite 0 direcionamento das orientações ministradas às mães; e para as mães supre o descontentamento com informações contraditórias, pois com o material as informações tornam-se padronizadas ${ }^{126}$.

O relato de descontentamento com informações contraditórias foi apontado em outro trabalho que construiu material educativo para pacientes renais. Neste, os pacientes referem que às vezes deparam-se com materiais educativos, mas que estes não suprem suas necessidades ${ }^{127}$.

Nos dados obtidos nas comunidades virtuais e no grupo focal, observou-se que os pacientes submetidos à cirurgia ortognática demonstraram o descontentamento com a falta de informação existente sobre a cirurgia, e percorreram o período perioperatório sem informação ou orientação mais detalhada. Esse fato pode fazer o paciente buscar informações em internet ou outros meios e que muitas vezes não são fidedignas. Isso pode ser decorrente da construção de materiais sem avaliação prévia do público alvo, escrito apenas com base no que o profissional acredita ser importante para o paciente, sem que este faça parte do desenvolvimento do conteúdo.

O uso crescente de materiais educativos, como um dos recursos da educação em saúde, abre novas possibilidades no processo de ensino aprendizagem por meio de interações mediadas pelo locutor (profissional de 
saúde), o paciente e a família (leitor) e o material educativo escrito (objeto do discurso), trazendo desafios e exigindo definições claras dos objetivos educacionais a serem atingidos pelo público-alvo ${ }^{140}$.

O educador em saúde deve acreditar que o conhecimento dá responsabilidade e autonomia à pessoa para viver de maneira mais digna e humana, ou seja, ajuda o paciente a tomar decisões e desenvolver habilidades para cuidar de si, emancipando-o ${ }^{127}$.

Para um material sobre determinada cirurgia, a educação pode conscientizar familiares e pacientes em reconhecer precocemente complicações, diminuir o medo e a ansiedade, lidar melhor com o estresse. Entretanto, para alcançar esse objetivo, os materiais devem ser eficazes, atender a uma capacidade de compreensão de grande parte populacional, estar adequado a sua cultura e ser sofisticado ${ }^{136}$.

Um estudo randomizado realizado no Reino Unido propõe a intervenção de um material educativo mais abrangente sobre a laparoscopia, incluindo possíveis complicações, e outro com informações superficiais e demonstra que 0 folheto contendo informações mais detalhadas foi associado a maior conhecimento sobre a laparoscopia, maior satisfação do paciente com o fornecimento das informações e diminuição da ansiedade perioperatória $^{141}$.

Atualmente, folhetos existentes no período pré-operatório estão disponíveis apenas para os procedimentos cirúrgicos mais comuns e devem, por necessidade, ser de natureza genérica para assegurar a aplicabilidade a todos os pacientes. Sendo assim, para um paciente submetido a um procedimento de várias etapas, um punhado de folhetos seriam necessários, o que provavelmente seria muito confuso para ele ${ }^{131}$.

A construção de materiais educativos específicos vem sendo uma prática crescente para enfermagem. Na literatura, estudos demonstram com variedade de metodologias o processo de construção de materiais educativos, bem como a aplicação de validação por parte do especialista e população. 
No desenvolvimento de práticas educativas, o enfermeiro deve ter, além da fundamentação científica, conhecimentos dos aspectos que levam em consideração os sentimentos, necessidades e desejos do paciente sob sua orientação ${ }^{127}$.

Convém dizer, que, habitualmente, uma criação de qualidade requer a conjunção de vários saberes: conceptuais, educativos, comunicacionais, artísticos e técnicos ${ }^{125}$.

Considerou-se como limitação do estudo a utilização de pacientes que possuem convênio médico e melhor acesso a informação e de apenas uma clínica de cirurgia ortognática, principalmente na avaliação do material educativo, pois as impressões sobre o material educativo podem retratar as características da clientela atendida nesse serviço. É provável que pacientes com menores níveis de escolaridade pontuassem negativamente 0 item da linguagem.

Uma amostra maior poderia trazer maiores contribuições em relação a comentários e representar melhor a população submetida a cirurgia ortognática.

Além disso, a utilização de instrumentos diferentes para a avaliação dos juízes e dos pacientes não permitiu estabelecer uma relação entre as percepções de ambos os grupos. 


\section{CONSIDERAÇÕES FINAIS}

A proposta de construir um material educativo baseado no conhecimento das perspectivas que o envolve foi ousada para ser concluída em 24 meses, mas possível de ser realizada. Os dados obtidos atingiram os objetivos do estudo, que resultaram em uma tecnologia educativa para educação pós-operatória dos pacientes submetidos a cirurgia ortognática.

Considerando a análise conjunta dos itens de avaliação concordo e concordo totalmente, tanto nos dados dos pacientes quanto naqueles relativos aos juízes, pode-se alcançar a meta mínima de 70,0\% de concordância para cada dimensão dos instrumentos de avaliação adotados. Muitos acreditam que a construção de materiais educativos se dá de forma simples, como colocar as ideias em um folder e entregar ao paciente. Entretanto, no dia-a-dia de nossas atividades nos deparamos com pacientes que não aderem a esse método de cuidado, porque não conseguem entender o que está escrito, não conseguem ler ou simplesmente o formato do material não os atrai.

Logo, pode-se dizer que um material educativo envolve mais do que colocar ideias resumidas em um papel e entregá-lo ao paciente. É preciso conhecer essa população, envolver profissionais que atuam nesse tratamento e buscar melhores proporções gráficas para um material educativo.

Não faz parte de nossa realidade o aprendizado de como prover materiais educativos. Muitas vezes, a enfermagem nem está envolvida neste processo de construção. Muitas instituições tem usado o material educativo como material de divulgação de seus serviços, com poucas informações que realmente interessem ao paciente.

E se "as imagens valem por mais de mil palavras", a atuação de um desenhista era fundamental para construção deste trabalho. As imagens auxiliam a fixar o conhecimento, esclarecer 0 texto e tornar atrativo 0 
material educativo, além de que, a aplicação de desenhos torna-se mais aceitável do que fotografias.

No decorrer desta pesquisa, todos os envolvidos em um processo perioperatório participaram da construção de um método educativo, demonstrando a atuação da equipe multiprofissional ao paciente que assistem. O conhecimento científico, aliado ao trabalho em equipe e ao paciente que recebe o material, foram inseridos na construção e validação deste.

A busca de um referencial teórico deu ao pesquisador domínio sobre o assunto para que fosse possível coordenar ideias e montar o primeiro esboço do material educativo, que também contou com o conhecimento da população virtual e presencial, além do brainstorming dos juízes.

Na tentativa de ampliar o conhecimento da população e devido à consciente interação virtual, comunidades virtuais e blogs não poderiam ficar de fora desta pesquisa. Apesar de inovadora, a utilização das informações virtuais foi enriquecedora.

A contribuição dos pacientes internautas e participantes do grupo focal trouxe dúvidas que muitas vezes o profissional não considera por serem básicas ao olhar do profissional, mas que se tornam essenciais ao paciente.

Nota-se que pacientes em comunidades virtuais falam abertamente de seus medos e dúvidas, o que deixa de ocorrer durante uma consulta médica, quando o paciente tem vergonha de expor sua dúvida por achar que pode ser uma pergunta boba.

No meio virtual também se percebe que pacientes trocam informações sobre cuidados ou experiências vivenciadas no pós-operatório, o que demonstra a fragilidade das orientações recebidas pelo profissional, seja porque ele não absorve todas as orientações verbais ou porque não as recebeu. 
O fato é que isso pode agravar o processo de recuperação, uma vez que, o paciente realiza cuidados não indicados ao seu caso de recuperação; não procura o profissional precocemente frente a uma dúvida ou complicação agravando o caso.

Esta lacuna de orientação pode ser preenchida pelo material educativo. Não se espera que o paciente leia todo o material de uma única vez, mas que ele o tenha sempre para rever as orientações recebidas verbalmente, buscar esclarecimentos, prevenir complicações e prover melhor recuperação.

Para avaliação do material educativo construído, a contribuição de peritos e pacientes para validação do processo é requerida. Entretanto, notase que não há uma forma padronizada para avaliar a concordância no processo de validação dos juízes. Alguns estudos aplicam avaliação qualitativa outros quantitativas, mas sem uma padronização. Considerando que os valores alcançados nesta pesquisa são superiores a $70 \%$ de concordância, pode-se dizer que foram satisfatórios os resultados alcançados dentro do método aplicado.

Todo o trabalho despendido na construção de um material com tanto cuidado não tem valor se o paciente não é capaz de compreendê-lo. Frente a isso, a validação de leitura por uma amostra de pacientes fez parte do método desta pesquisa, para que todo o trabalho de construção do material educativo não se perdesse simplesmente porque o paciente não consegue entender as orientações, o que o levaria o paciente a abandonar o material e não aplicá-lo ao seu autocuidado. 


\section{REFERÊNCIAS}

1 Proffit WR. Etiologia de los problemas ortodóncios. In: Fields HW, Sarver DM. Ortodoncia Contemporánea: Elsevier; 2007. p. 130-61.

2 Sora C, Jaramillo PM. Diagnóstico de las asimetrías faciales y dentales. Rev Fac Odontol Univ Antioquia.2005 Jun;16(1/2):15-25.

3 Miguel Neto AB, Mucha JN. Classificações das maloclusões - uma nova proposta. Ortodontia Gaucha.2000 Jan;IV(1):41-58.

4 Reis SAB. Parâmetros faciais e dentários de referencia para indicação do tratamento ortodôntico-cirurgico em pacientes com deformidades dentofaciais do padrão II [tese]. Faculdade de Odontologia da Universidade de São Paulo, 2008.

5 Martins AS, Cotrim-Ferreira FA. Classificação das Más Oclusões. In: Ferreira FV. Ortodontia-Diagnóstico e Planejamento Clínico: Artes Médicas; 2010. p. 99-115.

6 Rosa LP, Pastori CM, Marzola C, Toledo Filho JL, Dal Ponte GL. Prevalência das más oclusões em pacientes com deformidade dentofacial na cidade de Bauru, São Paulo, Brasil. Revista ATO.2009;534-44.

7 Leite PCC, Camarini ET, Filho LI, Pavan ÂJ, Farah GJ, Silva MB. Estudo epidemiológico das deformidades dentofaciais de Maringá/PR 1997 - 2003. Pesqui Bras Odontopediatria Clín Integr.2004 Set;4(3):217-20.

8 Espeland L, Hogevold HE, Stenvik A. A 3-year patient-centred follow-up of 516 consecutively treated orthognathic surgery patients. Eur $J$ Orthod.2008 Feb;30(1):24-30.

9 Ribas MO, Reis LFG, França BHS, Lima AAS. Cirurgia ortognática: orientações legais aos ortodontistas e cirurgiões bucofaciais. Rev Dent Press Ortodon Ortopedi Facial.2005 Nov;10(6):75-83. 
10 Lima Júnior N, Moro MA, Tanaka FY, Souza-Fattah CMR, Renon MA. O que significa cirurgia ortognática? Arq Ciências Saúde UNIPAR.1999 Set;3(3):273-6.

11 Laureano Filho JR, Silva EDO, Vasconcellos RJH, Silva LCF, Rocha NS. Alterações estéticas em discrepâncias ânteroposteriores na cirurgia ortognática. Rev Cir Traumatol Buco-maxilo-fac.2005 Jan;5(1):45-52.

12 Laureano Filho JR. Cirurgia ortognática combinada: relato de um caso clinico. Rev Cir Traumatol Buco-maxilo-fac.2002 Jun;2(1):31-41.

13 Araújo AM, Araujo A, Araujo MM. Orientação ao paciente com vistas à cirurgia ortognática: o ponto de vista do ortodontista. Rev Clín Ortodon Dental Press.2005 Out;4(5):99-105.

14 Sant'Ana E, Janson M. Ortodontia e cirurgia ortognática - do planejamento à finalização . Rev Dent Press Ortodon Ortop Maxilar.2003 Mai;8(3):119-29.

15 Bezerra MF. Estudo epidemiológico dos pacientes hospitalizados e atendidos pelo serviço de cirurgia e traumatologia bucomaxilofacial do Hospital São Lucas, Porto Alegre, 2000 a 2005 [dissertação]. Faculdade de Odontologia da Pontifica Universidade Catolica do Rio Grande do Sul, 2006.

16 Veronez FS, Tavano LDA. Modificações psicossociais observadas póscirurgia ortognática em pacientes com e sem fissura labioplatinas. Arq Ciênc Saúde.2005 Jul;12(3):133-7.

17 Dimitroulis G. A simple classification of orthognathic surgery complications. Int J Adult Orthodon Orthognath Surg.1998;13(1):79-87.

18 Steuer K, Addante RR, Strong J. Orthognathic surgery. Restoring form and function of the jaw. AORN J.1989 Sep;50(3):536-43, 546.

19 Osorio Giraldo OI, Ortíz Orrego GE. Cirugía ortognática en pacientes en crecimiento. CES Odontol.2002 Jul;15(2):63-8.

20 Hummes B, Moesh A, Schneider LE, Crusius KC, Lima PVP, Grasselli $S$, et al. Complicações no tratamento cirurgico da deficiência transversa do osso maxilar. Stomatos.2008 Jul;14(27):63-73. 
21 Gealh WC, Iwaki Filho L. Acidentes e complicações em cirurgia ortognática. Rev clín ortodon Dental Press.2008 Abr;7(2):95-102.

22 Cove P. Surgery for jaw deformity. In: Yates C. A manual of oral and maxillofacial surgery for nurses. USA: Blackwell Science; 2000. p. 12541.

23 Nicodemo D, Pereira MD, Ferreira LM. Cirurgia ortognática: abordagem psicossocial em pacientes Classe III de Angle submetidos à correção cirúrgica da deformidade dentofacial. Rev Dent Press Ortodon Ortopedi Facial.2007 Set;12(5):46-54.

24 Abernathy W, McDaniel M, Edwards R, Kiely K, Frazier D. Nonmetallic fixation in elective maxillofacial surgery. AORN J.2000 Jan;71(1):193-8.

25 Gomide ACM, Pereira HO, Buccholz I, Martins VLV. Cuidados de enfermagem no pós-operatório de paciente com trauma buco-maxilofacial: revisão de literatura. Rev Enferm UFPE on-line.2009;3(1):86-92.

26 Christóforo BEB, Carvalho DS. Cuidados de enfermagem realizados ao paciente cirurgico no periodo pré-operatório. Rev Esc Enferm USP.2009 Mar;43(1):14-22.

27 Moraes LOd, Peniche AdCG. Assistência de Enfermagem no período de recuperação anestésica: revisão de literatura. Rev Esc Enferm USP.2003;37:34-42.

28 Wolfe SA. Preoperative, intraoperative, and postoperative patient care in maxillofacial surgery. Clin Plast Surg.1989 Oct;16(4):659-64.

29 Grando TA, Puricelli E, Bagatini A, Baião CG. Anestesia para a cirurgia ortognática. 2004 p. s/n.

30 Peskin RM, Sachs SA. Intraoperative management of a partially severed endotracheal tube during orthognathic surgery. Anesth Prog.1986 Sep;33(5):247-51.

31 Whitesides LM, Exler AS. Intraoperative damage and correction of pilot balloon during orthognathic surgery. Anesth Prog.1997;44(1):38-9. 
32 Grando TA, Puricelli E, Bagatini A, Gomes CR, Baião CG, Ponzoni D. Alterações pós-anestésicas do hematócrito em cirurgias ortognáticas. Rev Bras Anestesiol.2005 Jan;55(1):78-86.

33 Francisco L. DS, Jaramillo V. PM. Complicaciones asociadas con osteotomía Le Fort I. Rev Fac Odontol Univ Antioquia.2009 Jun;20(2):205-21.

34 Kahnberg KE, Vannas-Lofqvist L, Zellin G. Complications associated with segmentation of the maxilla: a retrospective radiographic follow up of 82 patients. Int J Oral Maxillofac Surg.2005 Dec;34(8):840-5.

35 Panula K, Finne K, Oikarinen K. Incidence of complications and problems related to orthognathic surgery: a review of 655 patients. $J$ Oral Maxillofac Surg.2001 Oct;59(10):1128-36.

36 Acebal-Bianco F, Vuylsteke PL, Mommaerts MY, De Clercq CA. Perioperative complications in corrective facial orthopedic surgery: a 5year retrospective study. J Oral Maxillofac Surg.2000 Jul;58(7):754-60.

37 Kim SG, Park SS. Incidence of complications and problems related to orthognathic surgery. J Oral Maxillofac Surg.2007 Dec;65(12):2438-44.

38 Gunaseelan R, Anantanarayanan P, Veerabahu M, Vikraman B, Sripal R. Intraoperative and perioperative complications in anterior maxillary osteotomy: a retrospective evaluation of 103 patients. J Oral Maxillofac Surg.2009 Jun;67(6):1269-73.

39 Morris DE, Lo LJ, Margulis A. Pitfalls in orthognathic surgery: avoidance and management of complications. Clin Plast Surg.2007 Jul;34(3):1729.

40 Alpha C, O'Ryan F, Silva A, Poor D. The incidence of postoperative wound healing problems following sagittal ramus osteotomies stabilized with miniplates and monocortical screws. J Oral Maxillofac Surg.2006 Apr;64(4):659-68.

41 Rossi LA, Torrati FG, Carvalho EC, Manfrim A, Silva DF. Diagnósticos de enfermagem no paciente do período pós-operatório imediato. Rev Esc Enferm USP.2000 Jun;34(2):154-64. 
42 Pereira AAS. Centro de atenção especializada em cirurgias crâniomaxilo-faciais. Caderno de Enfermagem em Ortopedia [períodico na Internet]. 2009 Mai [citado 25 Jan 2011];2:6-8. Disponível em: http://bvsms.saude.gov.br/bvs/publicacoes/caderno enfermagem ortop edia v2.pdf.

43 Araújo AM, Araujo A, Araujo MM. Cirurgia Ortognática: soluçäo ou complicaçäo? um guia para o tratamento ortodôntico-cirurgico. Rev Dent Press Ortodon Ortop Maxilar.2000 Set;5(5):105-22.

44 Velásquez M, Correa PE. Cirugía ortognática y complicaciones anestésicas postoperatorias.Clínica CES Prado 1998-2001. CES Odontologia.2002 Jul;15(2):31-5.

45 el Deeb M, Wolford L, Bevis R. Complications of orthognathic surgery. Clin Plast Surg.1989 Oct;16(4):825-40.

46 Essick GK, Phillips C, Turvey TA, Tucker M. Facial altered sensation and sensory impairment after orthognathic surgery. Int J Oral Maxillofac Surg.2007 Jul;36(7):577-82.

47 Chow LK, Singh B, Chiu WK, Samman N. Prevalence of postoperative complications after orthognathic surgery: a 15-year review. J Oral Maxillofac Surg.2007 May;65(5):984-92.

48 D'Agostino A, Trevisiol L, Gugole F, Bondi V, Nocini PF. Complications of orthognathic surgery: the inferior alveolar nerve. J Craniofac Surg.2010 Jul;21(4):1189-95.

49 Nesari S, Kahnberg KE, Rasmusson L. Neurosensory function of the inferior alveolar nerve after bilateral sagittal ramus osteotomy: a retrospective study of 68 patients. Int J Oral Maxillofac Surg.2005 Jul;34(5):495-8.

50 Teltzrow T, Kramer FJ, Schulze A, Baethge C, Brachvogel P. Perioperative complications following sagittal split osteotomy of the mandible. J Craniomaxillofac Surg.2005 Oct;33(5):307-13.

51 Lee JG, Kim SG, Lim KJ, Choi KC. Thermographic assessment of inferior alveolar nerve injury in patients with dentofacial deformity. J Oral Maxillofac Surg.2007 Jan;65(1):74-8. 
52 Colella G, Cannavale R, Vicidomini A, Lanza A. Neurosensory disturbance of the inferior alveolar nerve after bilateral sagittal split osteotomy: a systematic review. J Oral Maxillofac Surg.2007 Sep;65(9):1707-15.

53 Liporaci Junior JLJ, Stoppa P, Ribeiro HT, Borin Neto AJ, Sverzut CE. Reabsorção condilar progressiva da articulação temporomandibular após cirurgia ortognática. Rev Dent Press Ortodon Ortopedi Facial.2007 Mar;12(2):38-48.

54 Peres SPBA, Arena EPA, Burini RC, Suguimoto RM. Uso de suplementos alimentares e estado nutricional de pacientes submetidos à cirurgia ortognática com bloqueio maxilo-mandibular. Rev Bras Nutr Clin.2006;21(1):28-32.

55 Giacobbo J, Mendel MIL, Borges WD, El-Kik RM, Oliveira RB, Silva DN. Assessment of nutritional anthropometric parameters in adult patients undergoing orthognathic surgery. Rev Odonto Ciênc.2009 Jan;24(1):956.

56 Laine $\mathrm{P}$, Kontio $\mathrm{R}$, Lindqvist $\mathrm{C}$, Suuronen $\mathrm{R}$. Are there any complications with bioabsorbable fixation devices? A 10 year review in orthognathic surgery. Int J Oral Maxillofac Surg.2004 Apr;33(3):240-4.

57 Kuhlefelt M, Laine $\mathrm{P}$, Suominen-Taipale L, Ingman T, Lindqvist C, Thoren $\mathrm{H}$. Risk factors contributing to symptomatic miniplate removal: a retrospective study of 153 bilateral sagittal split osteotomy patients. Int J Oral Maxillofac Surg.2010 May;39(5):430-5.

58 Ayoub AF, Lalani Z, Moos KF, Wood GA. Complications following orthognathic surgery that required early surgical intervention: fifteen years' experience. Int $\mathrm{J}$ Adult Orthodon Orthognath Surg.2001;16(2):138-44.

59 Kaplan PA, Tu HK, Koment MA, Ruskin JD, Bennion J. Radiography after orthognathic surgery. Part II. Surgical complications. Radiology.1988 Apr;167(1):195-8.

60 Graziano KU, Lacerda RA, Turrini RTN, Bruna CQM, Silva CPR, Schmitt C, et al. Indicadores de avaliação do processamento de artigos odonto-médico-hospitalares: elaboração e validação. Rev Esc Enferm.2009;43(2-spe):1174-80. 
61 Kasahara K, Yajima Y, Ikeda C, Kamiyama I, Takaki T, Kakizawa T, et al. Systemic Inflammatory Response Syndrome and postoperative complications after orthognathic surgery. Bull Tokyo Dent Coll.2009 Feb;50(1):41-50.

62 Quevedo Rojas LA. Osteotomía sagital de rama mandibular en cirugía ortognática. Rev Esp Cir Oral Maxilofac.2004;26(1):14-21.

63 Araujo A. Cirurgia Ortognática. 1aㅡ ed. Santos: 1999.

64 Almeida Junior JC, Cavalcante JR. Osteotomia sagital do ramo mandibular e osteotomia total de maxila. Pesqui Bras Odontopediatria Clín Integr.2004 Set;4(3):249-58.

65 Barreto GM, Gardini Jr LG, Raveli DB, Oliveira CA. Avaliação transversal e vertical da maxila, após expansão rápida, utilizando um método de padronização das radiografias póstero-anteriores. $\mathrm{R}$ Dental Press Ortodon Ortop Facial.2005 Dez;10(6):91-102.

66 Capelloza Filho L, Silva Filho OG. Expansão Rápida da Maxila: Considerações Gerais e Aplicação Clínica. Parte I. Rev Dent Press Ortodon Ortop Maxilar.1997 Mai;2(3):88-102.

67 Scavavini MA, Reis SAB, Simoes MM, Gonçalves RAR. Avaliação comparativa dos efeitos maxilares da expansão rápida da maxila com os aparelhos de Haas e Hyrax. R Dental Press Ortodon Ortop Facial.2006 Jan;11(1):60-71.

68 Sofia OB, Telles PAS, Dolci JEL. Mentoplastia no tratamento das deformidades do queixo. Rev Bras Cir Craniomaxilofac.2009;12(4):16973.

69 Guedes VMC, Silva LF, Freitas MC. Educação em saúde: objeto de estudo em dissertações e teses de enfermeiras no Brasil. Rev Bras Enferm.2004 Nov;57(6):662-5.

70 Carvalho VLS, Clementino VQ, Pinho LMO. Educação em saúde nas páginas da REBEn no perído de 1995 a 2005. Rev Bras Enferm.2008 Mar;6(12):243-8. 
71 Magalhães CR, Guimarães EC, Aguiar BGC. O papel do enfermeiro educador: ação educativa do enfemreiro no pré e pós-operatório. $R$ de Pesq: cuidado é fundamental.2004;8(1/2):115-9.

72 Rothrock J.C. Alexander Cuidados de Enfermagem ao Paciente Cirúrgico. USA: Elsevier; 2007. Conceitos básicos de enfermagem perioperatória; p. 1-14.

73 Fox VJ. Educação do paciente e planejamento de alta. In: Rothrock JC. Alexander Cuidados de Enfermagem ao Paciente Cirúrgico. USA: Elsevier; 2007. p. 271-96.

74 Zago MM, Casagrande LDR. A comunicaçäo do enfermeiro cirúrgico na orientaçäo do paciente: a influência cultural. Rev Lat Am Enfermagem.1997 Out;5(4):69-74.

75 Friedlander MR, Lage OC. O acompanhamento do paciente pós cirúrgico por meio da visita domiciliária. Acta Paul Enferm.2003 Jan;16(1):49-55.

76 Silva LGDM. Problemas de usuários cirúrgicos após a alta hospitalar identificando fatores condicionantes do processo cirúrgico e suas implicações para a assistências perioperatória [dissertação]. Escola de Enfermagem da Universidade de São Paulo, 2004.

77 Organização Pan-Americana da Saúde. Carta de Ottawa. Primeira Conferência Internacional sobre Promoção da Saúde [períodico na Internet]. 1986 Novembro [citado 20 Abr 2011];Disponível em: http://www.opas.org.br/promocao/uploadAra/Ottawa.pdf.

78 Pontes AC, Leitão IMTA, Ramos IC. Comunicação terapêutica em Enfermagem: instrumento essencial do cuidado . Rev Bras Enferm.2008 Mai;61(3):312-8.

79 Houts PS, Doak CC, Doak LG, Loscalzo MJ. The role of pictures in improving health communication: a review of research on attention, comprehension, recall, and adherence. Patient Educ Couns.2006 May;61(2):173-90.

80 Kessels RP. Patients' memory for medical information. J R Soc Med.2003 May;96(5):219-22. 
81 Panobianco MS, Souza VP, Prado MAS, Gozzo TO, Magalhães PAP, Almeida AM. Construção do conhecimento necessário ao desenvolvimento de um manual didático-instrucional na prevenção do linfedema pós-mastectomia. Texto Contexto Enferm.2010 Jul;18(3):418-26.

82 Monsivais D, Reynolds A. Developing and evaluating patient education materials. J Contin Educ Nurs.2003 Jul;34(4):172-6.

83 Doak CC, Doak LG, Root J.Teaching patients with low literacy skills. Philadelphia (PA): J.B.Lippincott; 1996. The Literacy problem; p. 1-10.

84 Ribeiro VM. Analfabetismo e alfabetismo funcional no Brasil. Boletim INAF.2006 Jul;1-2.

85 Sand-Jecklin K. The impact of medical terminology on readability of patient education materials. J Community Health Nurs.2007;24(2):11929.

86 Alexander RE. Patient understanding of postsurgical instruction forms. Oral Surgery Oral Medicine Oral Pathology Oral Radiology and Endodontics.1999 Feb;87(2):153-8.

87 Ivnik $M$, Jett MY. Creating written patient education materials. Chest.2008 Apr;133(4):1038-40.

88 Pierce LL. How to choose and develop written educational materials. Rehabil Nurs.2010 May;35(3):99-105.

89 Tang PC, Newcomb C. Informing patients: a guide for providing patient health information. J Am Med Inform Assoc.1998 Nov;5(6):563-70.

90 Currie K, Spink J, Rajendran M. Well-Written Health Information: a Guide. 1 ed. Department of Human Services Victoria: 2000.

91 Aldridge MD. Writing and designing readable patient education materials. Nephrol Nurs J.2004 Jul;31(4):373-7.

92 Doak CC, Doak LG, Root J. Teaching patients with low literacy skills. Philadelphia (PA): J.B.Lippincott; 1996. Writing the message; p. 73-90. 
93 Wilson FL, Mood DW, Risk J, Kershaw T. Evaluation of education materials using Orem's self-care deficit theory. Nurs Sci Q.2003 Jan;16(1):68-76.

94 Hoffmann T, Worrall L. Designing effective written health education materials: considerations for health professionals. Disabil Rehabil.2004 Oct 7;26(19):1166-73.

95 Frost $\mathrm{MH}$, Thompson $\mathrm{R}$, Thiemann KB. Importance of format and design in print patient information. Cancer Pract.1999 Jan;7(1):22-7.

96 Delp C, Jones J. Communicating information to patients: the use of cartoon illustrations to improve comprehension of instructions. Acad Emerg Med.1996 Mar;3(3):264-70.

97 Doak C, Doak L, Root J. Teaching patients with low literacy skills. Philadelphia (PA): J.B.Lippincott; 1996. Assessing Suitability of Materials; p. 41-60.

98 Benefield LE. Implementing evidence-based practice in home care. Home Healthc Nurse.2003 Dec;21(12):804-11.

99 Souza MT, da Silva MD, de Carvalho R. Revisão integrativa: o que é? e como fazer?. Einstein.2010;8(1):102-6.

100 Bock JJ, Maurer P, Otto C, Fuhrmann RA, Schubert J. Complications of orthodontic-orthognathic surgery treatment in mentally handicapped patients. J Craniomaxillofac Surg.2006 Apr;34(3):156-61.

101 Kobayashi A, Yoshimasu H, Kobayashi J, Amagasa T. Neurosensory alteration in the lower lip and chin area after orthognathic surgery: bilateral sagittal split osteotomy versus inverted $L$ ramus osteotomy. J Oral Maxillofac Surg.2006 May;64(5):778-84.

102 Essick GK, Austin S, Phillips C, Kiyak HA. Short-term sensory impairment after orthognathic surgery. Oral Maxillofac Surg Clin North Am.2001 May;13(2):295-313.

103 Lee KJ, Park YC, Park JY, Hwang WS. Miniscrew-assisted nonsurgical palatal expansion before orthognathic surgery for a patient with severe mandibular prognathism. Am J Orthod Dentofacial Orthop.2010 Jun;137(6):830-9. 
104 Spaey YJ, Bettens RM, Mommaerts MY, Adriaens J, Van Landuyt HW, Abeloos $\mathrm{JV}$, et al. A prospective study on infectious complications in orthognathic surgery. J Craniomaxillofac Surg.2005 Feb;33(1):24-9.

105 Aoyama S, Kino K, Kobayashi J, Yoshimasu H, Amagasa T. Clinical evaluation of the temporomandibular joint following orthognathic surgery--multiple logistic regression analysis. J Med Dent Sci.2005 Jun;52(2):109-14.

106 Mehra P, Castro V, Freitas RZ, Wolford LM. Complications of the mandibular sagittal split ramus osteotomy associated with the presence or absence of third molars. J Oral Maxillofac Surg.2001 Aug;59(8):854-8

107 Kriwalsky MS, Maurer P, Veras RB, Eckert AW, Schubert J. Risk factors for a bad split during sagittal split osteotomy. $\mathrm{Br} \mathrm{J}$ Oral Maxillofac Surg.2008 Apr;46(3):177-9.

108 Dimitroulis G. Complications of orthognathic surgery. Aust Orthod J.1996 Oct;14(3):158-61.

109 Colbert S, Cameron M, Williams J. Septic thrombosis of the cavernous sinus and dental infection. Br J Oral Maxillofac Surg.2010 Aug;49(6):256.

110 Campos CJG. Método de análise de conteúdo: ferramenta para a análise de dados qualitativos no campo da saúde. Rev Bras Enferm.2004 Sep;57(5):611-4.

111 Bardin L. Análise de Conteúdo. Lisboa: Edições 70; 2009.

112 Shuyler KS, Knight KM. What are patients seeking when they turn to the Internet? Qualitative content analysis of questions asked by visitors to an orthopaedics Web site. J Med Internet Res.2003 Oct 10;5(4):24.

113 Aldairy T, Laverick S, Mclntyre GT. Orthognathic surgery: is patient information on the Internet valid? The European Journal of Orthodontics.2011 Mar:1-4.

114 lervolino SA, Pelicioni MCF. A utilização do grupo focal como metodologia qualitativa na promoção da saúde. Rev Esc Enferm USP.2001 Jun;35(2):115-21. 
115 Dall'Agnol CM, Trench $\mathrm{MH}$. Grupos focais como estratégia metodológica em pesquisas na enfermagem. Rev Gaucha Enferm.1999 Jan;20(1):5-25.

116 Faria Westphal M, Bogus CM, Mello Faria M. Grupos focais: experiências precursoras em programas educativos em saúde no Brasil. Bol Oficina Sanit Panam.1996 Jun;120(6):472-82.

117 Wright JTC, Giovinazzo RA. Delphi - uma ferramenta de apoio ao planejamento prospectivo. Caderno de Pesquisas em Administração.2000 Apr;1(12):54-65.

118 Dalkey NC. The Method Delphi: an experimental study of group opinion. Santa Monica (CA): Rand Corporation; 1969. p. 1-87.

119 Oliveira JSP, Costa MM, Wille MFC. Introdução ao Método Delphi. Curitiba: Mundo Material; 2008. p. 1-18.

120 Spínola AWP. Delfos: proposta tecnológica alternativa. Faculdade de Saúde Publica da USP.1984;-91.

121 Faro ACM. Técnica Delphi na validação das intervenções de enfermagem. Rev Esc Enferm USP.1997 Ago;31(1):259-73.

122 Keeney S, Hasson F, McKenna HP. A critical review of the Delphi technique as a research methodology for nursing. Int J Nurs Stud.2001 Apr;38(2):195-200.

123 Rea LM, Parker RA. Metodologia da Pesquisa: do planejamento a execução: Ed Thomson Pioneira; 2000. Desenvolvendo perguntas para a pesquisa; p. 57-76.

124 Oliveira MS. Autocuidado da mulher na reabilitação da mastectomia: estudo de validação de aparência e conteúdo de uma tecnologia educativa [dissertação]. Fortaleza: Universidade Federal do Ceará Faculdade de Farmácia, Odontologia e Enfermagem, 2006.

125 Kaplún G. Material educativo1: a experiência de aprendizado. Comunicação e Educação.2003;27:46-60. 
126 Fonseca LMM, Scochi CGS, Rocha SMM, Leite AM. Cartilha educativa para orientação materna sobre os cuidados com o bebê prematuro. Rev Lat-Am de Enferm.2004;12:65-75.

127 Queiroz MVO, Dantas MCdQ, Ramos IC, Jorge MSB. Tecnologia do cuidado ao paciente renal crônico: enfoque educativo-terapêutico a partir das necessidades dos sujeitos. Texto \& ContextoEnfermagem.2008;17:55-63.

128 Toral N, Conti MA, Slater B. A alimentação saudável na ótica dos adolescentes: percepções e barreiras na sua implementação e características esperadas em materiais educativos. Cadernos de Saúde Pública.2009;25:2386-94.

129 Rozemberg B, Silva APPd, Vasconcellos-Silva PR. Impressos hospitalares e a dinâmica de construção de seus sentidos: o ponto de vista dos profissionais de saúde. Cadernos de Saúde Pública.2002;18:1685-94.

130 Zombini EV, Pelicioni MCF. Estratégias para a avaliação de um material educativo em saúde ocular. Revista Brasileira de Crescimento e Desenvolvimento Humano.2011;21:51-8.

131 Dimarco C, Bray P, Covvey HD, Cowan DD, Diciccio V, Hovy E, et al. Authoring and generation of individualized patient education materials. AMIA Annu Symp Proc.2006;195-9.

132 Vasconcellos-Silva PR, Uribe Rivera FJ, Castiel LD. Comunicação instrumental, diretiva e afetiva em impressos hospitalares. Cadernos de Saúde Pública.2003;19:1667-79.

133 Doak CC, Doak LG, Friedell GH, Meade CD. Improving comprehension for cancer patients with low literacy skills: strategies for clinicians. CA Cancer J Clin.1998 May;48(3):151-62.

134 Readence JE, Moore DW. A meta-analytic review of the effect of adjunct pictures on reading comprehension. Psychol Schs.1981;18(2):218-24.

135 Moll JM. Doctor-patient communication in rheumatology: studies of visual and verbal perception using educational booklets and other graphic material. Ann Rheum Dis.1986 Mar;45(3):198-209. 
136 Seth S. How readability of patient materials affects. Journal of Vascular Nursing.2000 Sep;18(3):97-101.

137 Reberte LM. Celebrando a vida: construção de uma cartilha para promoção da saúde da gestante [dissertação]. São Paulo: Escola de Enfermagem da USP, 2008.

138 Kubota N, Oshiro JH, Balduino MA, Faria Zd. Avaliação de material educativo: adequação de quatro volantes sobre alimentação da criança de 0 a 12 meses de idade. Revista de Saúde Pública.1980;14:101-22.

139 Gonçales MB, Barbieri M, Gabrielloni MC. Teste de papanicolau:construção e validação de material educativo para usuárias de serviços de saúde. Sáude Coletiva.2008;05(20):39-44.

140 Freitas AAdS, Cabral IE. O cuidado à pessoa traqueostomizada: análise de um folheto educativo. Escola Anna Nery.2008;12:84-9.

141 Garrud P, Wood M, Stainsby L. Impact of risk information in a patient education leaflet. Patient Educ Couns.2001 Jun;43(3):301-4. 


\section{APENDICE A}

\section{Carta de Solicitação de Autorização ao Consultório da BMF}

NOME DA PESQUISA: "Educação pós-operatória: construção e validação de uma tecnologia educativa para pacientes submetidos a cirurgia ortognática" o objetivo é elaborar e validar um material educativo para os pacientes submetidos à cirurgia ortognática

\section{Prezado (a) Senhor (a),}

Para tal solicito a autorização desta instituição para acompanhar o paciente submetido à cirurgia ortognática em seu pós-operatório e realizar a orientação referente ao objeto da pesquisa (material educativo), procedendo com a coleta de dados para aqueles que de livre e espontânea vontade vierem a aderir à pesquisa. Caberá a estes avaliar o material educativo quanto à compreensão.

Aos pacientes será entregue o termo de consentimento livre e esclarecido, um instrumento de caracterização do grupo, um exemplar do material educativo e um instrumento especifico para realizar a avaliação do material.

Os resultados obtidos desta pesquisa serão organizados e apresentados em eventos científicos nacionais e internacionais e publicados em revistas científicas pertinentes. A instituição não será revelada em nenhum momento da pesquisa, será mantida a confidencialidade, bem como não caberá a esta instituição nenhum prejuízo com a realização desta pesquisa.

Estando de acordo com a realização desta pesquisa, 


\section{APENDICE B}

\section{Termo de Consentimento Livre e Esclarecido}

NOME DA PESQUISA: "Educação pós-operatória: construção e validação de uma tecnologia educativa para pacientes submetidos a cirurgia ortognática", o objetivo é elaborar e validar um material educativo para os pacientes submetidos à cirurgia ortognática.

\section{Prezado (a) Senhor (a),}

Eu, Cristina Silva Sousa, aluna do mestrado do programa de pós-graduação na saúde do adulto da Escola de Enfermagem da USP (EEUSP) em São Paulo, peço sua colaboração nesta pesquisa para participar de uma discussão em grupo com outros pacientes sobre sua cirurgia ortognática. As informações obtidas nesta discussão auxiliarão na construção de um material educativo para pacientes que se submetem à cirurgia ortognática.

A conversa do grupo será gravada para que seja possível transcrever todo o conteúdo para análise. Sua participação neste grupo será apenas para expor suas dúvidas em relação à cirurgia e aos cuidados necessários ou contar as dificuldades enfrentadas durante sua experiência

A sua participação no estudo é livre, podendo desistir a qualquer momento se nenhum prejuízo. Os resultados obtidos desta pesquisa serão organizados e apresentados em eventos científicos nacionais e internacionais e publicados em revistas científicas pertinentes. Seu nome não será revelado em nenhum momento da pesquisa, será mantido segredo, bem como a privacidade dos seus dados pessoais e da gravação.

Qualquer dúvida com relação aos aspectos éticos do projeto entrar em contato com o Comitê de Ética em Pesquisa EEUSP pelo e-mail: edipesq@usp.br. Em caso de dúvida você poderá entrar em contato com a pesquisadora Cristina Silva Sousa pelo telefone: 96017972 / 50833007 
Este termo será preenchido em duas vias, sendo uma entregue ao participante da pesquisa.

Nome:

$R G$ : data de nascimento

Endereço:

Telefone:

Declaro que, após ser esclarecido pelo pesquisador e ter entendido o que me foi explicado, consinto em participar desta pesquisa

São Paulo, de de

Assinatura do colaborador

Cristina Silva Sousa

Enfermeira perioperatória e aluna do Mestrado da Escola de Enfermagem da USP (EEUSP) 


\section{APENDICE C}

\section{Apresentação do material educativo e esclarecimento a respeito de sua colaboração como juiz.}

São Paulo, de de 2010

Caro (a) Juiz (a),

Obrigada por ter aceitado participar desta pesquisa como juiz (a), sua colaboração será muito importante para a construção do material educativo.

O conteúdo do material educativo é resultado de uma pesquisa de revisão da literatura para dar sustentação científica ao conteúdo; uma pesquisa nas comunidades virtuais e blogs para conhecer os interesses dos pacientes sobre a cirurgia ortognática; uma atividade de pesquisa desenvolvida junto a um grupo de pacientes em fase pré-operatório e pósoperatório da cirurgia ortognática mediante a técnica do grupo focal para conhecer a população a receber educação em saúde e a primeira fase da técnica Delphi com juízes com a questão: "o que é importante para orientação do paciente de cirurgia ortognática?"

As ilustrações serão realizadas por cartunista para personalizar adequadamente o material.

O seu trabalho consiste em uma primeira fase responder a pergunta aberta do impresso em anexo e posteriormente fazer a leitura critica do material educativo e preencher a avaliação que será enviada juntamente com o material. Este é composto por itens, e suas sugestões para aperfeiçoamento devem ser indicadas nos espaços reservados para esta finalidade. Você terá um prazo determinado para realizar este trabalho e após a devolução do instrumento de avaliação, serão feitas as alterações indicadas pelo conjunto dos juízes, assim como determina a técnica Delphi. 
O material educativo refeito segundo estes critérios será entregue para você realizar uma nova avaliação semelhante ao processo adotado anteriormente.

Quando o material for aprovado pelo grupo de juízes será entregue a um grupo de pacientes para avaliação conforme o instrumento Suitability Assessment of Materials (SAM), que consiste em indicar dificuldades de compreensão do texto e ilustrações, organização do material e leiaute. As sugestões realizadas serão incorporadas e o processo de avaliação repetido até o momento que seja obtido o nível de adequação de material educativo segundo o escore do instrumento.

Atenciosamente

Cristina Silva Sousa

Mestranda da EEUSP 


\section{APENDICE D}

Instrumento de coleta de dados para caracterização dos Juízes

Nome:

Idade:_. Tempo de experiência na área (em anos):

Formação:

Graduação:

Especialização:

Mestrado:

Doutorado:

Área de atuação:

Questão inicial para a rodada da Técnica Delphi:

O que é importante para orientação do paciente de cirurgia ortognática? 


\section{APENDICE E}

\section{Instrumento de Avaliação do Material Educativo -Parecer dos Juízes-}

Leia minuciosamente o material educativo. Em seguida, preencha o instrumento, marcando um $\mathbf{X}$ no item que corresponde a sua resposta. Não existem respostas corretas, o resultado deste reflete sua opinião. Por favor, responda todos os itens.

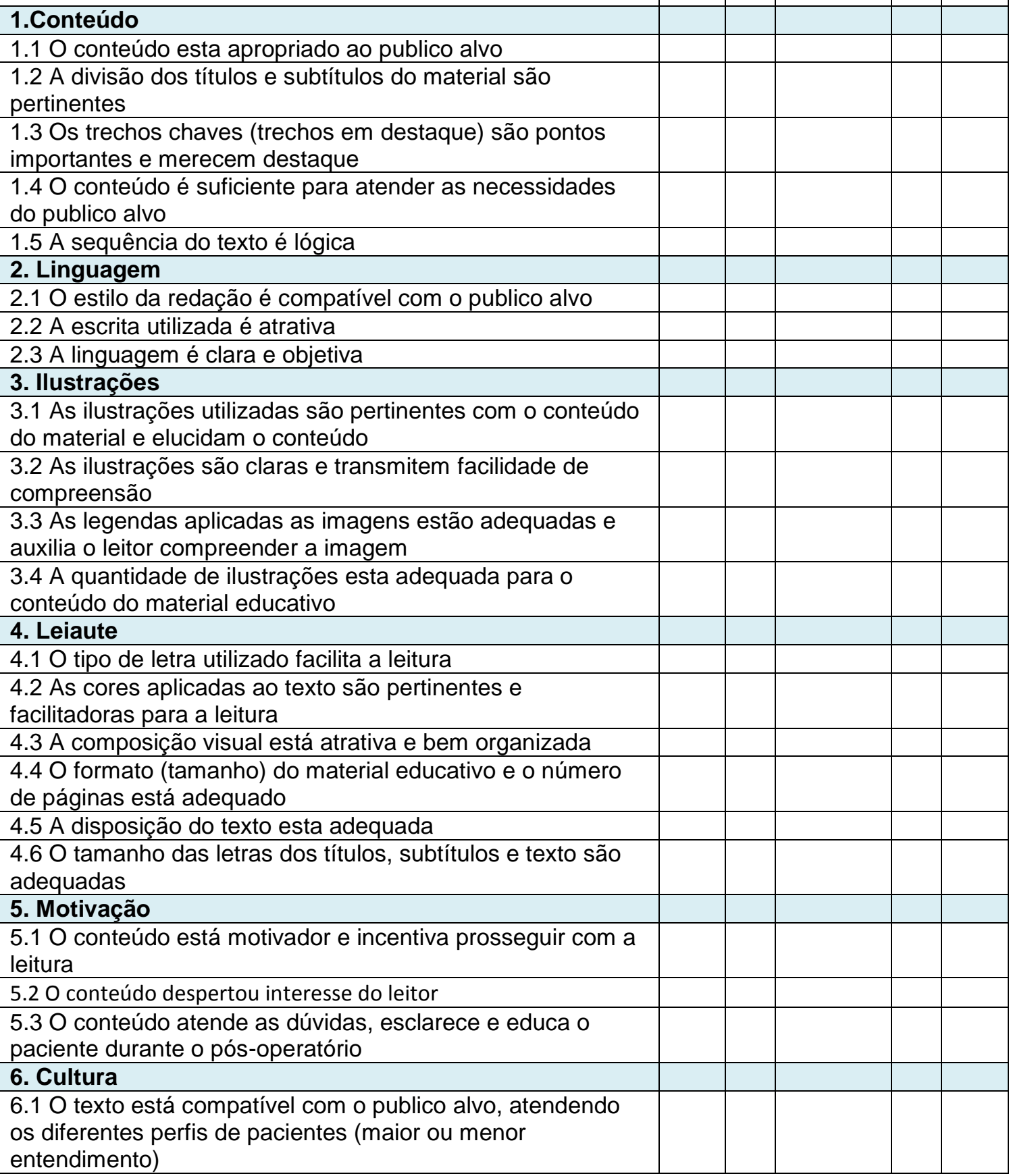


1. Você observou algum erro ou ideia prejudicial no material educativo? Por favor, indique a página e parágrafo e exponha sua opinião ou sugestão.

2. Você sentiu falta de alguma informação?

\section{Comentários}




\section{APENDICE F}

\section{Apresentação do material educativo e esclarecimento a respeito de sua colaboração como avaliador.}

São Paulo, de de 2010

Caro Paciente,

Obrigada por ter aceitado participar desta pesquisa, sua colaboração será muito importante para melhorar o material educativo.

O texto do material educativo é resultado de uma pesquisa de conteúdo científico; comunidades virtuais e blogs para conhecer os interesses dos publico sobre a cirurgia ortognática e uma atividade desenvolvida junto a um grupo de pacientes. Outros profissionais também estão ajudando a fazer este material educativo: cirurgiões, enfermeiros e nutricionistas.

Por favor, leia o material educativo, se achar necessário peça auxilio a um familiar ou podemos fazer juntos.

Responda o questionário enviado junto com o material conforme a explicação contida nele, cada pergunta avalia um contexto do material educativo.

Agora, faça um traço embaixo das palavras que são difíceis de entender e me diga que outra palavra poderá melhorar o entendimento. $E$ marque um $X$ ao lado da figura que você achou difícil de entender

Suas sugestões serão colocadas no material educativo e ele poderá será refeito. Isso será feito com outros pacientes também até que seja possível a todos os pacientes entender o conteúdo e imagens do material educativo.

Cristina Silva Sousa

Aluna da Escola de Enfermagem da Universidade de São Paulo 


\section{APENDICE G}

Instrumento de coleta de dados para caracterização dos pacientes

Nome:

Idade: . Estado civil:

Ocupação:

Escolaridade: ( ) sim ( ) não

Se sim:
(a) Alfabetizado
(b) Ensino fundamental incompleto
(c) Ensino fundamental completo
(d) Ensino médio incompleto
(e) Ensino médio completo
(f) Ensino superior incompleto
(g) Ensino superior completo
(h) Pós-graduação. Qual?

Tempo de preparo para cirurgia ortognática (uso de aparelho ortodôntico):
(a) 0-6 meses
(b) 7-12 meses
(c) 13-18 meses
(d) 19-24 meses

Você já realizou a cirurgia? (a) sim - há quanto tempo?

(b) não

Você costuma procurar informações sobre sua saúde na internet (sites, $\begin{array}{lll}\text { blogs, Orkut, Youtube)? (a) sim } & \text { (b) não }\end{array}$

O que levou você a procurar tratamento para seu problema de saúde? 


\section{APENDICE H}

\section{Termo de Consentimento Livre e Esclarecido do Paciente}

NOME DA PESQUISA: "Educação pós-operatória: construção e validação de uma tecnologia educativa para pacientes submetidos a cirurgia ortognática", o objetivo é elaborar e validar um material educativo para os pacientes submetidos à cirurgia ortognática.

\section{Prezado (a) Senhor (a),}

Eu, Cristina Silva Sousa, aluna do mestrado do programa de pós-graduação na saúde do adulto da Escola de Enfermagem da USP (EEUSP) em São Paulo, peço sua colaboração nesta pesquisa para saber se você consegue entender o conteúdo do material educativo para pacientes de cirurgia ortognática. Se o conteúdo não for claro gostaria de ter sua ajuda para trocar as palavras difíceis, por outras mais fáceis de entender.

Sua participação acontecerá nas seguintes atividades: leitura e registro de suas sugestões para facilitar o entendimento do texto do material educativo.

A sua participação no estudo é livre, podendo desistir a qualquer momento se nenhum prejuízo. Os resultados obtidos serão organizados e apresentados em eventos científicos nacionais e internacionais e publicados em revistas científicas pertinentes. Seu nome não será revelado em nenhum momento da pesquisa, será mantido segredo, bem como a privacidade dos seus dados pessoais

Qualquer dúvida com relação aos aspectos éticos do projeto entrar em contato com o Comitê de Ética em Pesquisa EEUSP pelo e-mail: edipesq@usp.br. Informo que, no caso de dúvidas você poderá entrar em contato com a pesquisadora Cristina Silva Sousa pelo telefone: 96017972 / 50833007 
A participação na pesquisa é livre e de espontânea vontade. Não há riscos de sofrer prejuízo nesta participação. Toda e qualquer dúvida que você tenha será esclarecida.

Este termo será preenchido em duas vias, sendo uma entregue ao participante da pesquisa

Nome:

$R G$ : data de nascimento

Endereço:

Telefone:

Declaro que, após ser esclarecido pelo pesquisador e ter entendido o que me foi explicado, consinto em participar desta pesquisa

São Paulo, de de USP (EEUSP) 


\section{APENDICE I}

\section{Instrumento de Avaliação do Material Educativo}

\section{- Parecer do Paciente -}

Leia minuciosamente o material educativo. Em seguida, preencha o instrumento, marcando um $\mathbf{X}$ no item que corresponde a sua resposta. Não existem respostas corretas, o resultado deste reflete sua opinião. Por favor, responda todos os itens.

\section{Objetivos}

1.1 Atende aos objetivos dos pacientes que fizeram a cirurgia ortognática e estão em processo pós-operatório

1.2 Ajuda durante o processo de pós-operatório

1.3 Esta adequado para ser usado por qualquer profissional envolvido no processo da cirurgia

\section{Organização}

2.1 A capa está atraente, indica o conteúdo do material

2.2 O tamanho do titulo da capa e dos subtítulos dentro do material estão adequados

2.3 Os tópicos seguem uma ordem

2.4 Há coerência entre as informações da capa, apresentação e sumario.

2.5 O material (papel, impressão) está adequado

2.6 O número de páginas esta adequado

2.7 Os temas retratam aspectos chaves importantes

\section{Estilo da escrita}

3.1 a escrita está em um estilo adequado ao paciente

3.20 texto é vivido e interessante. O tom é amigável

3.3 O vocabulário é acessível

3.4 Há associação do tema de cada sessão com o texto correspondente

\subsection{O texto está claro}

3.6 O estilo da redação corresponde ao nível de conhecimento do público-alvo

\section{Aparência}

4.1 As páginas ou sessões parecem organizadas

4.2 As ilustrações são simples

4.3 As ilustrações servem para complementar os textos

4.4 As ilustrações são expressivas e suficientes

\section{Motivação}

5.10 material esta apropriado para idade, gênero e cultura

5.2 O material apresenta lógica

$5.3 \mathrm{~A}$ interação é convidada pelo texto. Sugere ações

5.4 O material aborda assuntos necessários ao paciente que faz a cirurgia ortognática

5.5 Promove mudança de comportamento e atitude

5.6 O material propõe ao paciente conhecimento para realizar o autocuidado

\begin{tabular}{|c|c|c|c|c|}
\hline 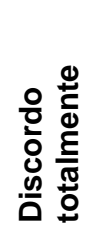 & $\begin{array}{l}\text { 음 } \\
\frac{0}{0} \\
\frac{0}{0}\end{array}$ & 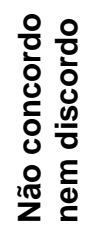 & 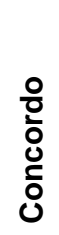 & 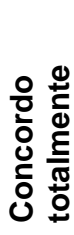 \\
\hline & & & & \\
\hline & & & & \\
\hline & & & & \\
\hline & & & & \\
\hline & & & & \\
\hline & & & & \\
\hline & & & & \\
\hline & & & & \\
\hline & & & & \\
\hline & & & & \\
\hline & & & & \\
\hline & & & & \\
\hline & & & & \\
\hline & & & & \\
\hline & & & & \\
\hline & & & & \\
\hline & & & & \\
\hline & & & & \\
\hline & & & & \\
\hline & & & & \\
\hline & & & & \\
\hline & & & & \\
\hline & & & & \\
\hline & & & & \\
\hline & & & & \\
\hline & & & & \\
\hline
\end{tabular}


Comentários e Sugestões 


\title{
ANEXO I
}

\section{Aprovação do comitê ética}

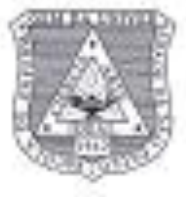

\author{
UNIVERSIDADE DE GĀO PAULO \\ ESCOLA DE ENFERMAGEM \\ Av, Or. Entas de Carvaho Aguier, 419 - CEP 05403-000 \\ Te.: \{011) 3061-75486858 - Fax (011) 3061-7548 - \\ S80 Paulo - SP - Brasi

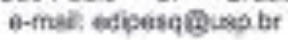

Slo Pulo, 25 de novembro de 2010,

Am. ${ }^{*}$ Sr."

Cristina Silva Sousa

Bef-Prosesse re 97220101 CEP.EFUSP

Prezada Senhara,

Em atenç̧o à solicitaçâ refereste á análise do projeto "Paeiente submetido à cirurgia ortognática: edueaçào ple-operatória", informansog que o mesnso foi considerado ipravale pelo Comitể de Étiea em Pesquisa da Escola de Enfermagem da Universidade de Ş̊ Paralo (CEP/EHUSP)

Analisado sob o aspecto etico-legal, stende às evightreias da Resoluça to 19696 do Conselho Nacional de Saíde.

Exclarecertsos gue após o têmmino da pesquisa, os resultados obtidos deverăo ser encaminhados a CEP/EEUSP, paes stren anexados no processo.

Alenciosametne.

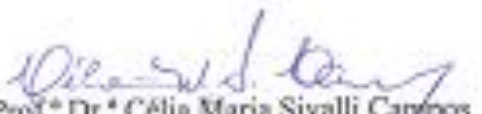

Pnot-Dr" Célia Maria Sivalli Canpos

Coordenadora do Coenitê \&e Êtica em/Pesquisa da

Escola de Enfermagem da Universidade de Siso Paulo 